Portland State University

PDXScholar

1987

\title{
A seismic refraction study of a portion of the northeastern margin of the Tualatin Valley, Oregon
}

David John Nazy

Portland State University

Follow this and additional works at: https://pdxscholar.library.pdx.edu/open_access_etds

Part of the Geology Commons, and the Geophysics and Seismology Commons

Let us know how access to this document benefits you.

\section{Recommended Citation}

Nazy, David John, "A seismic refraction study of a portion of the northeastern margin of the Tualatin Valley, Oregon" (1987). Dissertations and Theses. Paper 3723.

https://doi.org/10.15760/etd.5607

This Thesis is brought to you for free and open access. It has been accepted for inclusion in Dissertations and Theses by an authorized administrator of PDXScholar. Please contact us if we can make this document more accessible: pdxscholar@pdx.edu. 
AN ABSTRACT OF THE THESIS OF David John Nazy for the Master of Science in Geology presented July 17, 1987.

Title: A Seismic Refraction Study of a Portion of the Northeastern Margin of the Tualatin Valley, Oregon.

APPROVED BY MEMBERS OF THE THESIS COMMITTEE:

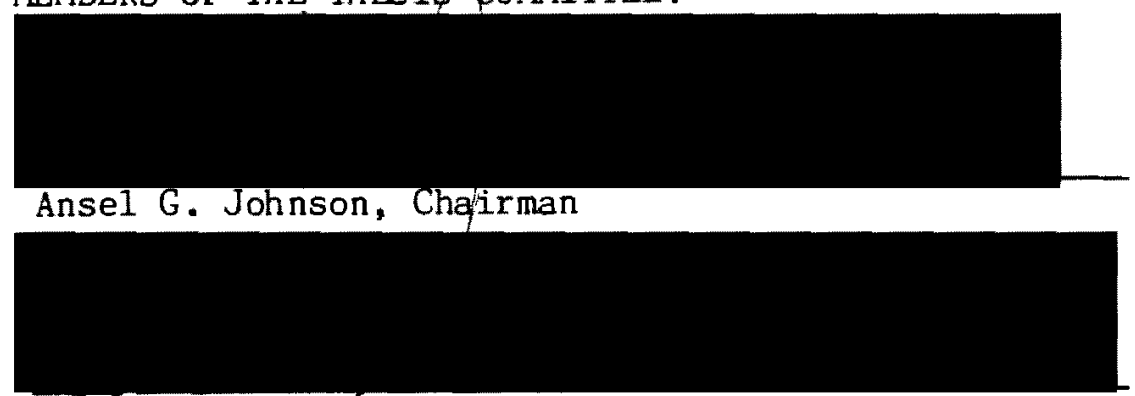

\#rvin H. Beeson

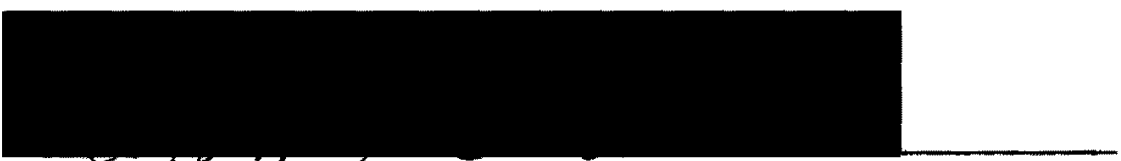

Gilbert'T. Bensón

The Tualatin Valley is a well defined elliptical basin centered at Hillsboro, with a major axis trending roughly $N 65^{\circ} \mathrm{W}$. The valley is bordered on the northeast by the Tualatin Mountains (Portland Hills) which are a faulted, northwest-trending asymmetrical anticline. Topographic and geophysical evidence have defined the Portland Hills fault, which occurs along the northeast side of the Tualatin Mountains. The possibility that a fault or fault zone occurs along the southwest side of the Tualatin Mountains was investigated in this study. 
Boring Lavas, occurring on the southwest side of the Tualatin Mountains and having been erupted through the Columbia River basalt, may define zones of fracture or faulting in the Columbia River basalt. An exposed "window" of sediment is located near the town of Bonny Slope on the southwest side of the Tualatin Mountains. This sedimentary unit is presumed to be marine in origin, stratigraphically below the Columbia River basalt. Exposure of this unit at this location may be the result of landsliding, faulting, or paleotopographic highs during the deposition of the Columbia River basalt.

Seismic refraction methods were used to produce shallow ( 0 - 50 meters) geologic models near the areas of the proposed fault zone. The refraction models indicate that Columbia River basalt roughly parallels the surface topography at an average depth of 15 meters and is overlain by a weathered zone ranging in thickness from 5 to 15 meters. The basalt is broken up into blocks, mainly in the southeastern half of the study area. Data collected through this study indicate that the sedimentary unit at Bonny Slope is not underlain by Columbia River basalt. This provides further evidence that this unit is part of the Scappoose Formation although it is uncertain as to whether this feature is related to faulting or paleotopographic highs. 
A SEISMIC REFRACTION STUDY

OF A PORTION OF THE NORTHEASTERN MARGIN

OF THE TUALATIN VALLEY, OREGON

by

DAVID JOHN NAZY

A thesis submitted in partial fulfillment of the requirements for the degree of

MASTER OF SCIENCE

in

GEOLOGY

Portland State University

1987 
TO THE OFFICE OF GRADUATE STUDIES AND RESEARCH:

The members of the Committee approve the thesis of David John Nazy presented July 17, 1987.

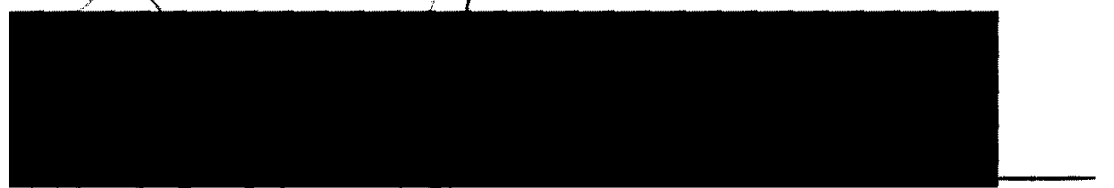

Ahsel G. Johnson, Chairman

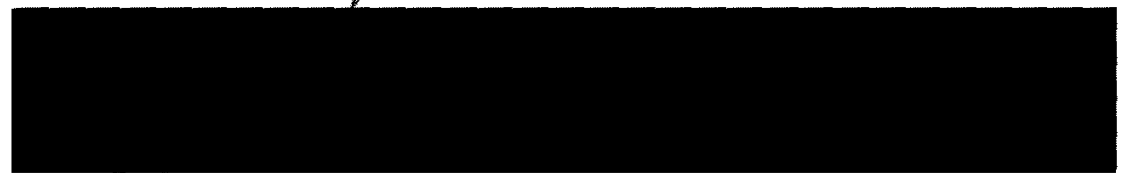

Marvin H. Beeson

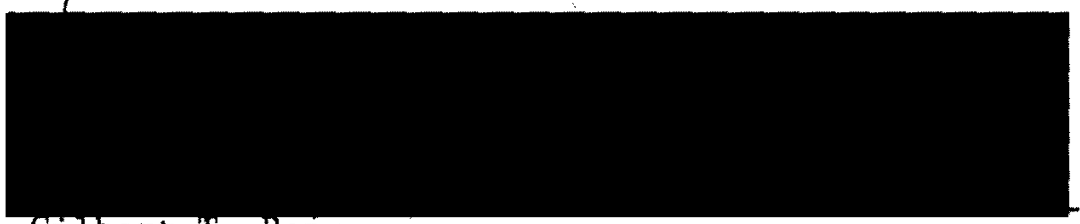

Gilbert T. Benson

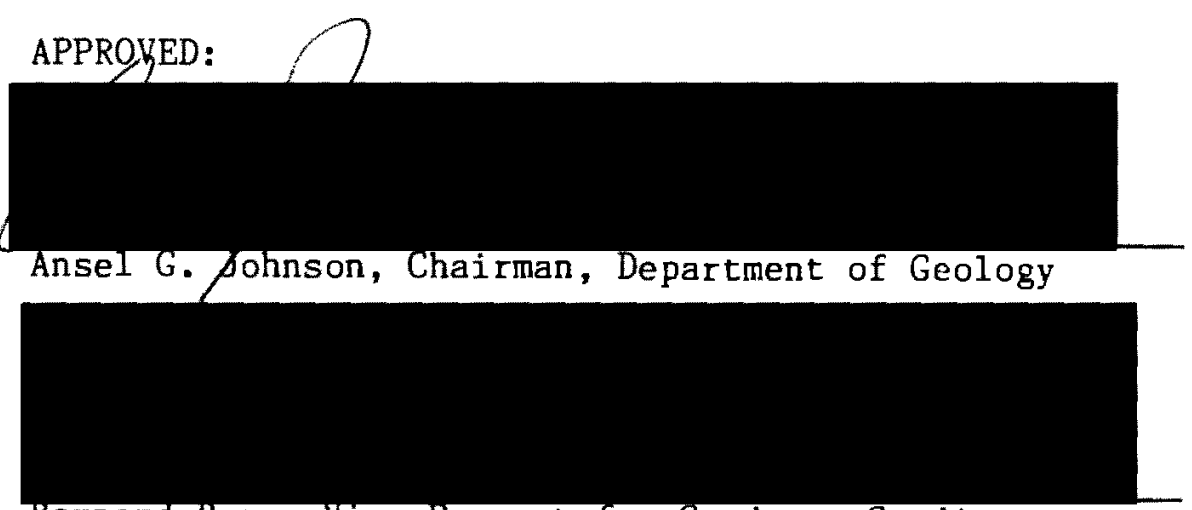

Bernard Ross, Vice Provost for Graduate Studies 


\section{ACKNOWLEDGEMENTS}

I would like to thank Ansel Johnson for his advice and helpful suggestions, use of his truck and assistance with field work, and unlimited use of his office and computer during the completion of my thesis. Thanks also go to Gene Pierson for helping get field work started and Mike Feves for providing funding for some of the field supplies. I also want to thank Dr. R.W. Couch at Oregon State University for loaning the thumper. Special thanks are due Marvin Beeson for useful suggestions and recommendations and to the other members of my thesis committee, G.T. Benson and Leonard Swanson for their review of the text.

I would also like to thank my friends who assisted with the field work, Dan Shrader, Erik Johnson, Blaine, and especially Ben Lill, who donated his truck and several hours of his time. I am also very grateful to my family and friends for all their encouragement and support along the way. 
TABLE OF CONTENTS

PAGE

ACKNOWLEDGEMENTS ............................. ii

LIST OF FIGURES . . . . . . . . . . . . . . . . . . vi

INTRODUCTION . . . . . . . . . . . . . . . . . . 1

PURPOSE .......................... 1

LOCATION ............................ 1

PREVIOUS WORK .................. 9

GEOLOGIC SETTING ................... 11

STRATIGRAPHY ........................... 11

STRUCTURE AND TECTONICS . . . . . . . . . . . . 15

METHODS OF INVESTIGATION ....................... 18

INTRODUCTION . . . . . . . . . . . . . . 18

PROCEDURES . . . . . . . . . . . . . . . . . 18

Field Techniques

Data Reduction

Equipment Used

GEOPHYSICAL MODELING . . . . . . . . . . . . . . . 23

SEISMIC REFRACTION . . . . . . . . . . . . . 23

RESULTS AND DISCUSSION . . . . . . . . . . . 27

Thompson Road Line

Bonny Slope Line

Laidlaw Road Line

Bronson Creek Line

Springuille Lane Line 1

Springville Lane Line 2

Germantown Road Line

Kaiser Road Line 
PAGE

Rock Creek Line

Cornelius Pass Line

SUMMARY AND CONCLUSTONS . . . . . . . . . . . . 51

REFERENCES CITED ................... . 61

APPENDIX A. REFRACTION DATA AND FORMULAS . . . . . . . . 66

APPENDIX B. FORTRAN PROGRAMS TO REDUCE DATA . . . . . . . 75 


\section{LIST OF FIGURES}

1. Regional Map.................. 2

2. Study Area .................. 3

3. Thompson Road and Bonny Slope Refraction Lines... . . . . . . . . . . . 5

4. Laidlaw Road, Bronson Creek, and

Springville Lane Refraction Lines... . . . . . 6

5. Germantown Road, Kaiser Road, and Rock

Creek Refraction Lines . . . . . . . . . . 7

6. Cornelius Pass Refraction Line... . . . . . . . 8

7. Earthquake Epicenters near the Tualatin

Valley ................. 10

8. Formations in Study Area ................ . 12

9. Typical Refraction Line Layout ............. . 20

10. Example of a Seismic Field Record . . . . . . . . . 21

11. Diagram Showing Paths of Seismic Waves

Leaving Source at Time of Impact . . . . . . . . 24

12. Thompson Road Refraction Line, Time-Distance

Plot and Generalized Cross Section . . . . . . . 28

13. Bonny Slope Refraction Line, Time-Distance

Plot and Generalized Cross Section ......... 30 
FIGURE

14. Laidlaw Road Refraction Line, Time-Distance

Plot and Generalized Cross Section ..........

15. Bronson Creek Refraction Line, Time-Distance

Plot and Generalized Cross Section . . . . . . .

16. Springville Lane Refraction Line 1, Time-

Distance Plot and Generalized Cross

Section ................. 38

17. Springuille Lane Refraction Line 2 Time-

Distance Plot and Generalized Cross

Section................ 40

18. Germantown Road Refraction Line, Time-Distance

Plot and Generalized Cross Section ........ . 42

19. Kaiser Road Refraction Line, Time-Distance

Plot and Generalized Cross Section ......... 45

20. Rock Creek Refraction Line, Time-Distance

Plot and Generalized Cross Section ........ . 47

21. Cornelius Pass Refraction Line, Time-Distance

Plot and Generalized Cross Section .........

22. Comparison and Interpretation of Cornelius

Pass, Rock Creek, Germantown Road, Kaiser Road, and Laidlaw Road Refraction Lines............ 52

23. Comparison and Interpretation of Springville

Lane Refraction Lines 1 and 2 ........... 54

24. Comparison and Interpretation of Thompson Road, Bonny

Slope, and Bronson Creek Refraction Lines....... 57 


\section{INTRODUCTION}

\section{PURPOSE}

The Tualatin Mountains (Portland Hills) are an expression of deformation of the Miocene Columbia River basalt. This study was undertaken to examine the shallow ( 0 - 50 meters) subsurface geology along the border of the Tualatin Mountains and the Tualatin Valley. The paucity of outcrops and the thick vegetative cover in the Tualatin Mountains makes a geophysical study the most reasonable method of investigating the structure in the area. This study has three main objectives: 1) to determine local thickness of the sediment or soil (weathered zone) overlying the Columbia River basalt; 2) to gain information about the upper surface of the Columbia River basalt and how it relates to the topography; 3) to look for displacement of refracting surfaces.

\section{LOCATION}

The study was conducted in Washington and Multnomah counties, Oregon (Figure 1). Ten seismic refraction lines were conducted along the western margin of the mapped surface exposure of the Columbia River basalt. The refraction surveys are spread out over 8.8 kilometers along the southwestern edge of the Tualatin Mountains. Figure 2 shows the location of the ten seismic lines and the mapped pattern of the major rock units in the study area. 


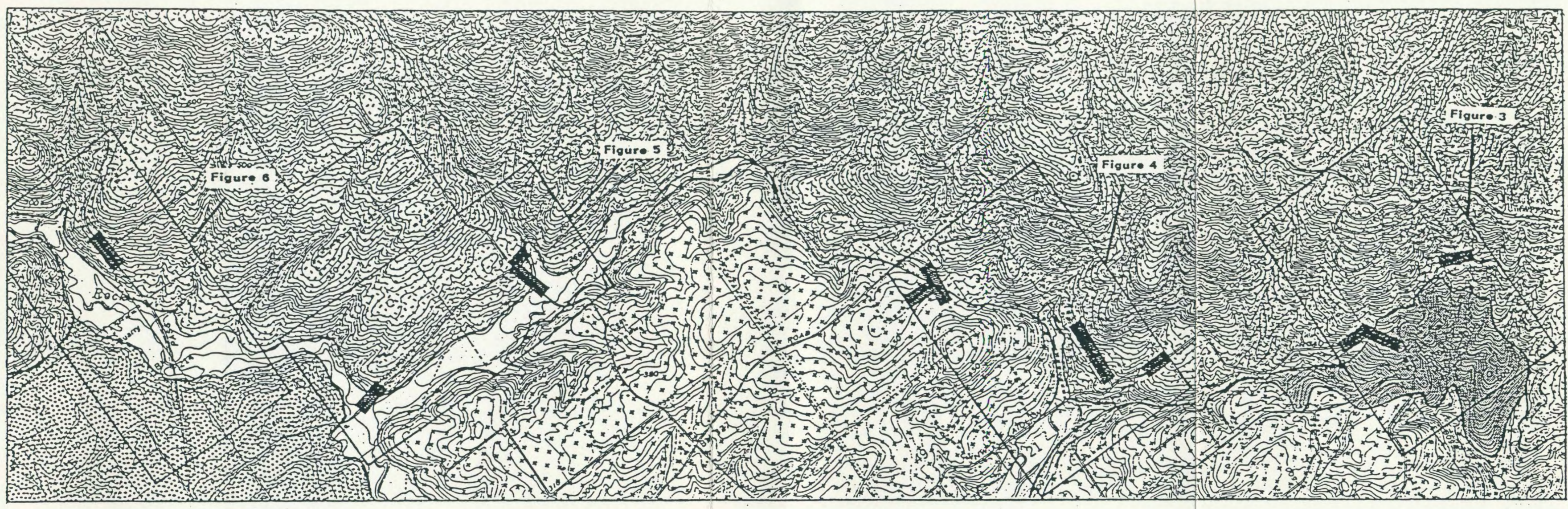

$\square$ Alluvium

LACUSTRINE DEPOSITS

+++ BORING LAVA

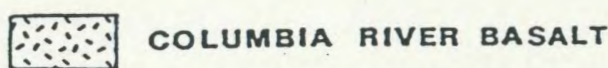

SCAPPOOSE FORMATION

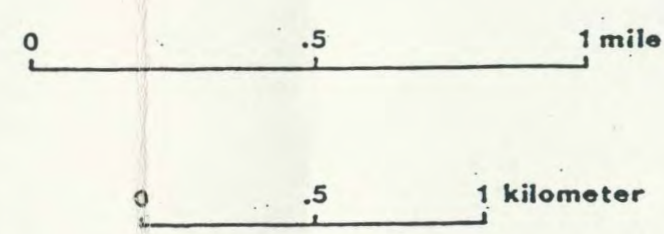

REFRACTION LINE

Figure 2. Study area (from. USGS 7.5'. Linnton quadrangle map, 1961). Modified from Trimble, 1963).

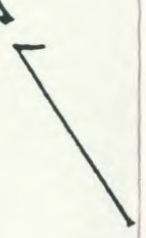




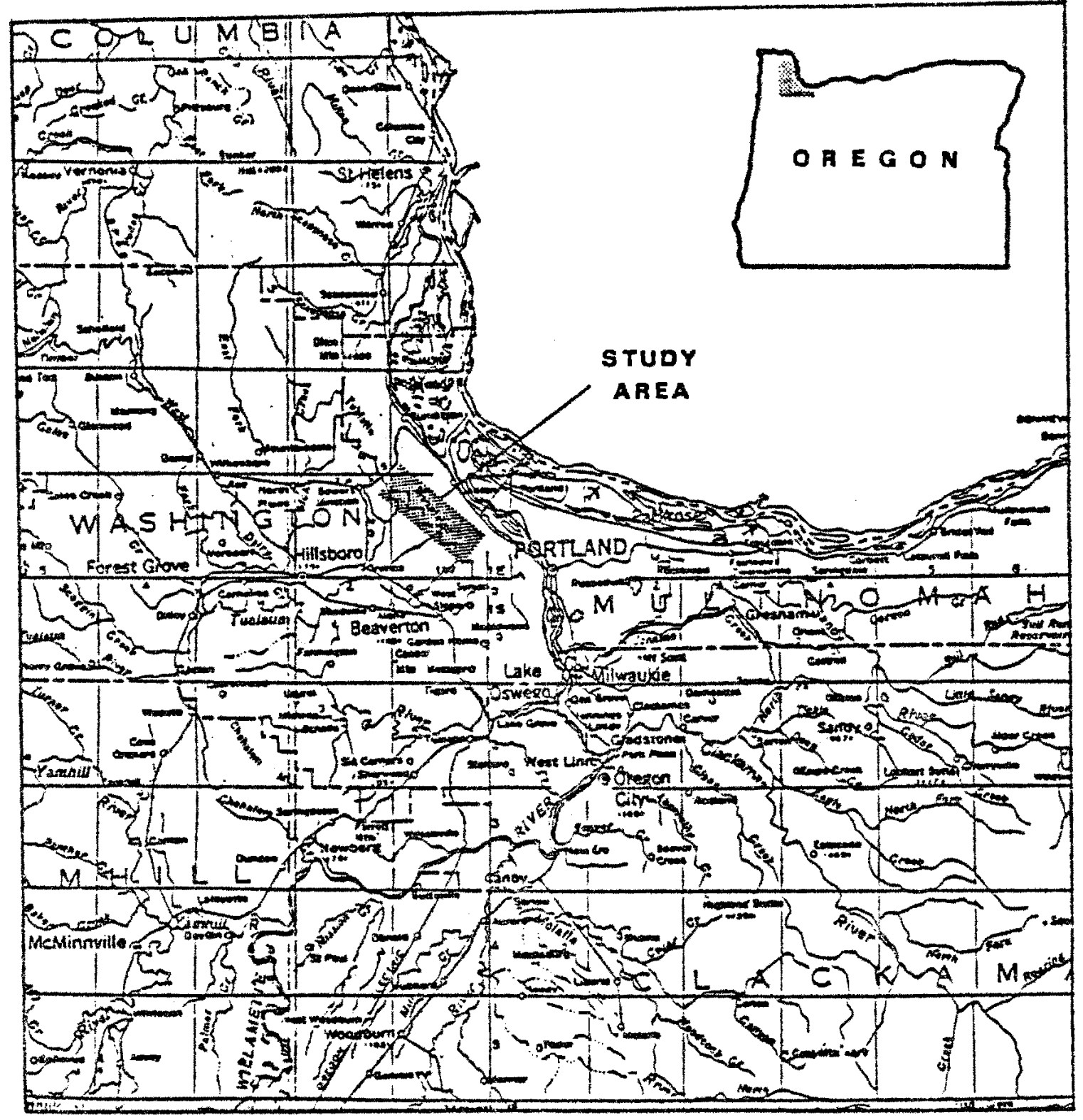

Eigure 1. Regional map (Erom USGS map of Oregon, 1966, .1:500,000). 
Geology and refraction line locations are shown in more detail in Figures $3-6$. The Thompson Road and Bonny Slope refraction lines are shown in Figure 3. The Thompson Road 1ine, 90 meters long, was conducted along NW Thompson Road in T1N, RlW, Sec. 23. The Bonny Slope refraction line, 350 meters in length, was run along the northern side of NW Laidlaw Road (T1N, R1W, Sec. 22 and 26).

Figure 4 shows the location of four seismic lines. The Laidlaw Road line was run a distance of 90 meters along NW Laidlaw Road. The Bronson Creek line, 360 meters in length, was run along NW 124th street. Both lines are located in T1N, RlW, Sec. 22. Two 180 meter lines were run perpendicular to each other along NW Springville Lane in T1N, R1W, Sec. 16 .

Another set of lines were run perpendicular to each other at the intersection of NW Kaiser Road and NW Germantown Road in T1N, R1W, Sec. 8 (Figure 5). A 180 meter line was run along the east edge of NW Kaiser Road and a 90 meter line was run along the south edge of NW Germantown Road. Rock Creek line, also shown in Figure 5, was run a distance of 145 meters along the north edge of NW Germantown Road in T1N, R1W, Sec. 7 .

Two 90 meter lines run along Cornelius Pass Road are shown in Figure 6. The lines were run on either side of the intersection with NW Kaiser Road in T1N, R1W, Sec. 6. 


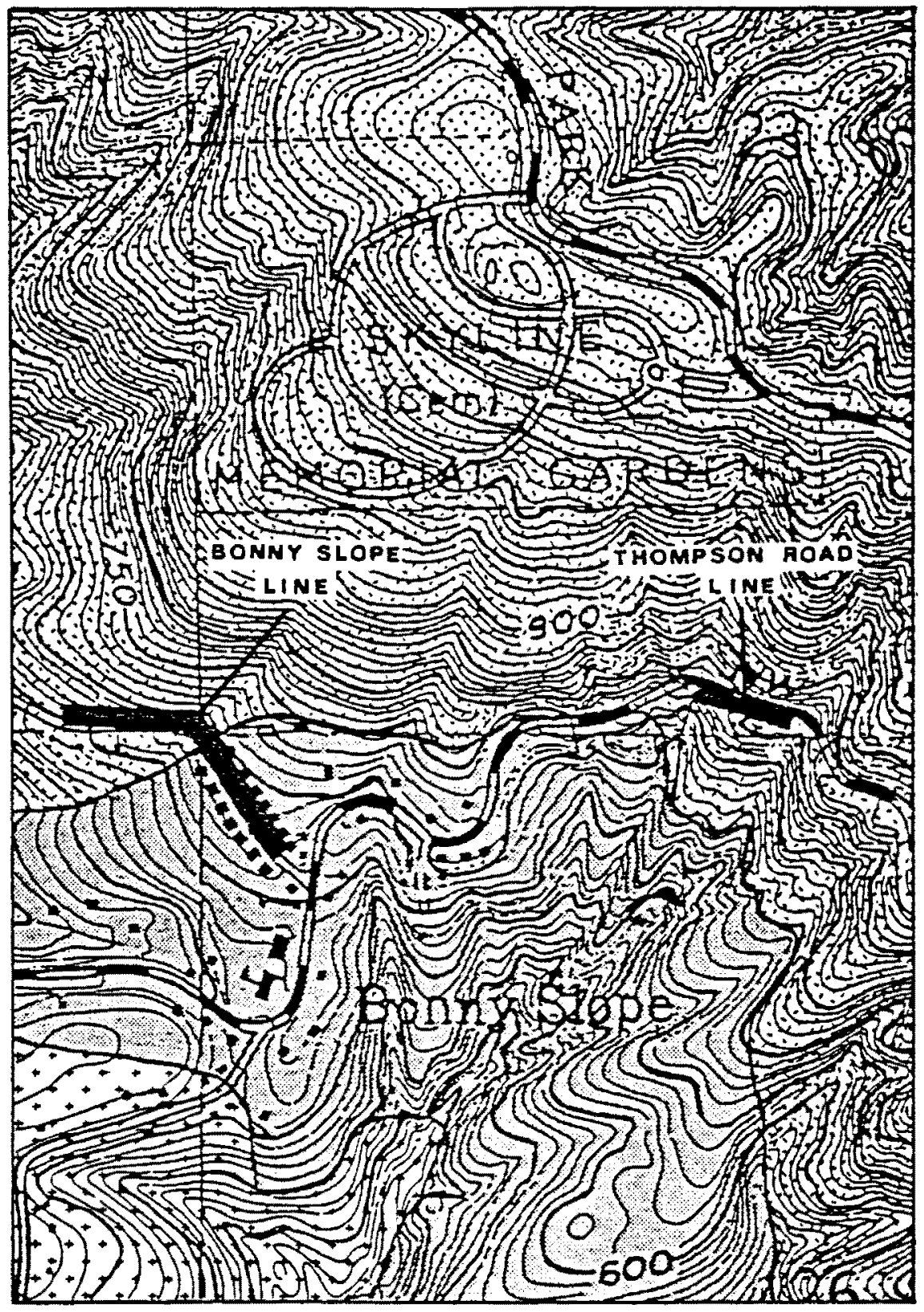

[*] Boring Lava

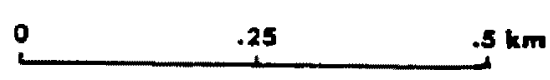

$\because \because \because:$ Columbie River Baelt

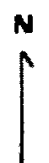

Seappoose Formetlon

Figure 3. Thompson Road and Bonny Slope refraction lines. (From USGS 7.5' Linnton quadrangle map, 1961). (Modified from Trimble, 1963 ). 


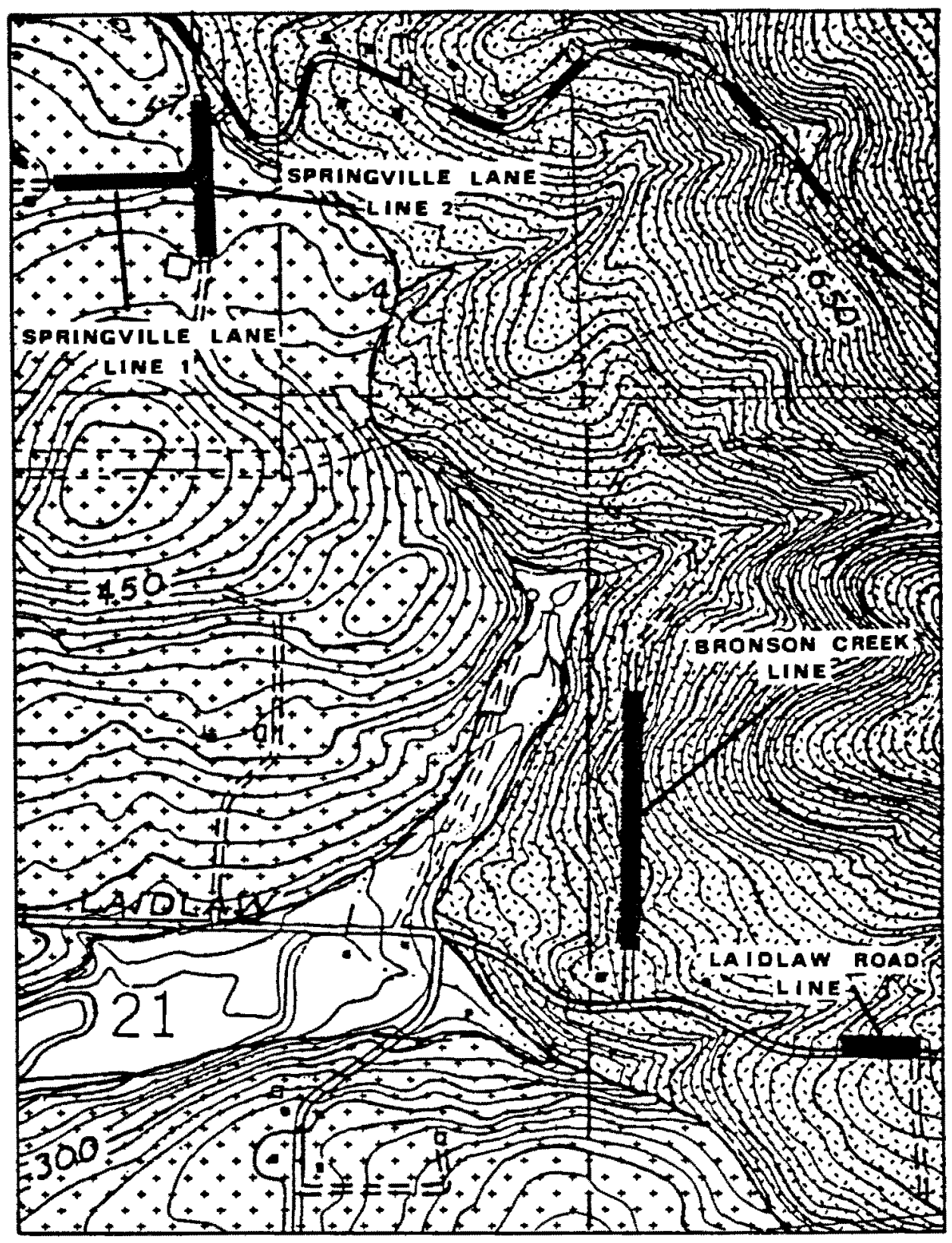

$\square$ Alluvium
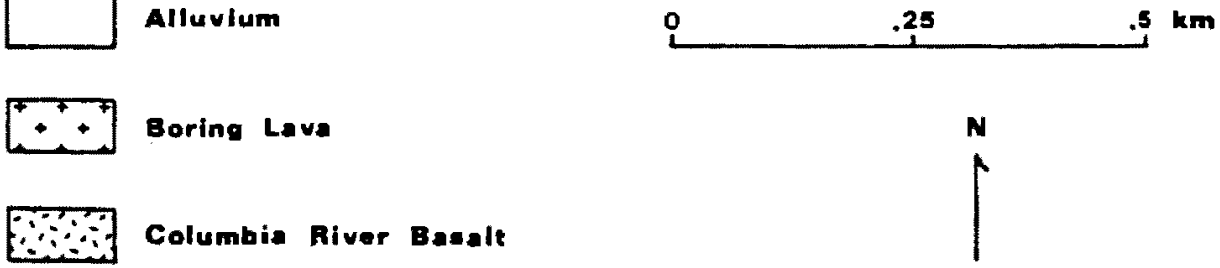

Figure 4. Laidlaw Road, Bronson Creek, and Springville Lane refraction 1 ines. (From USGS $7.5^{\circ}$ Linnton quadrangle map, 1961). (Modified from Trimble, 1963). 

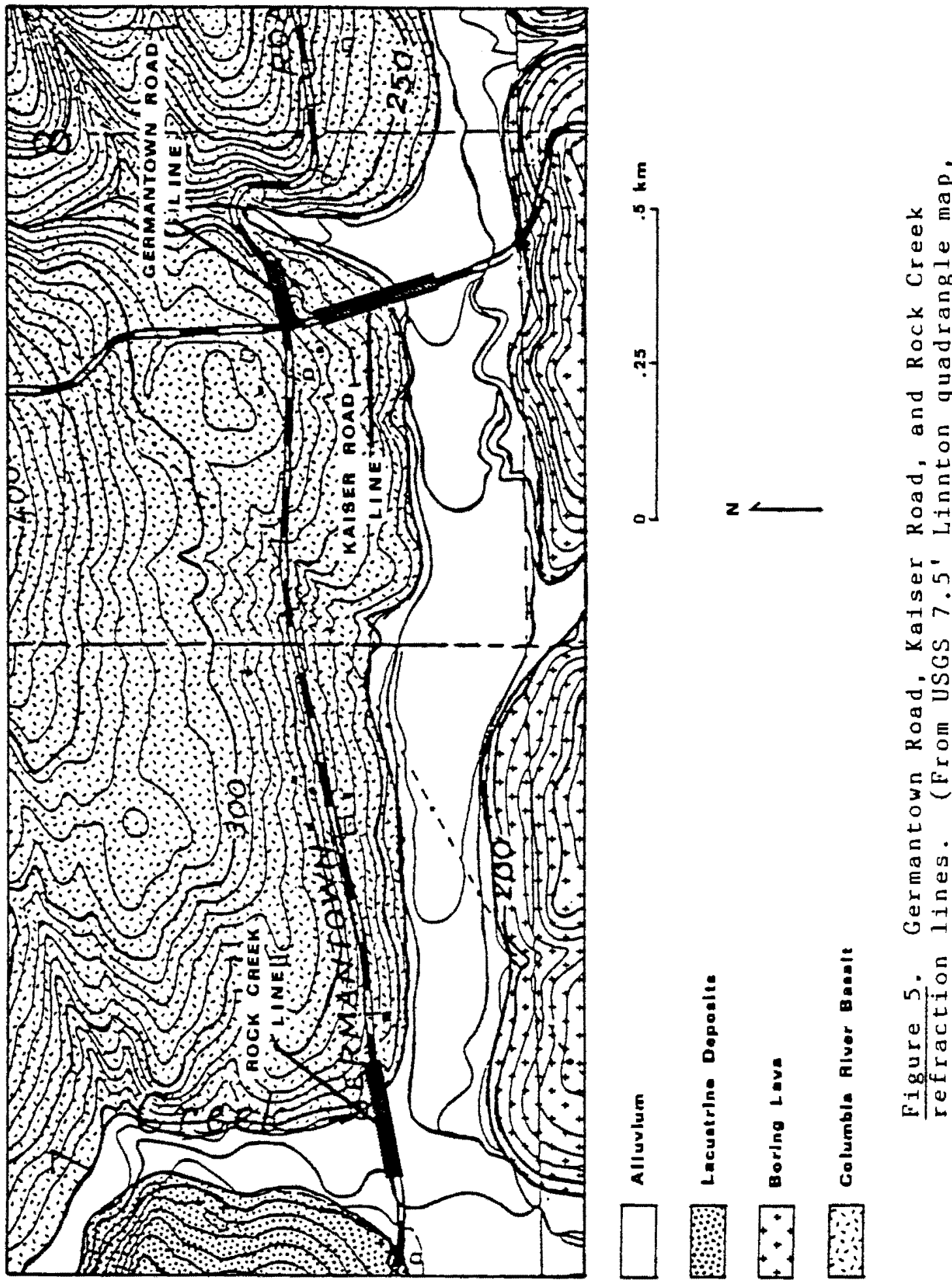

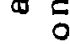

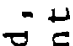

․ㅠ

$x-1$

-

4 in

को

(1)

4 en

0 -

○

$\stackrel{0}{0} \in$

둥

든

$0 \div 4$

$\stackrel{0}{\sigma}$

0 i

E U.

I $\simeq 4$

(1) .

에

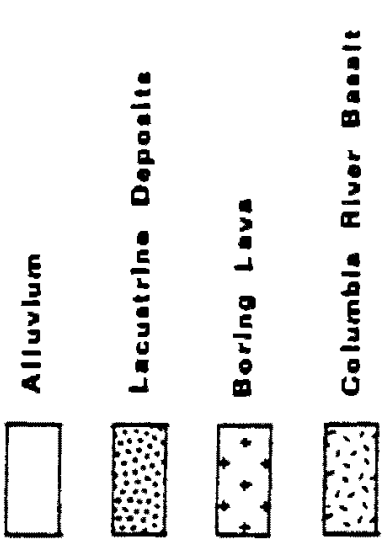

i|c 


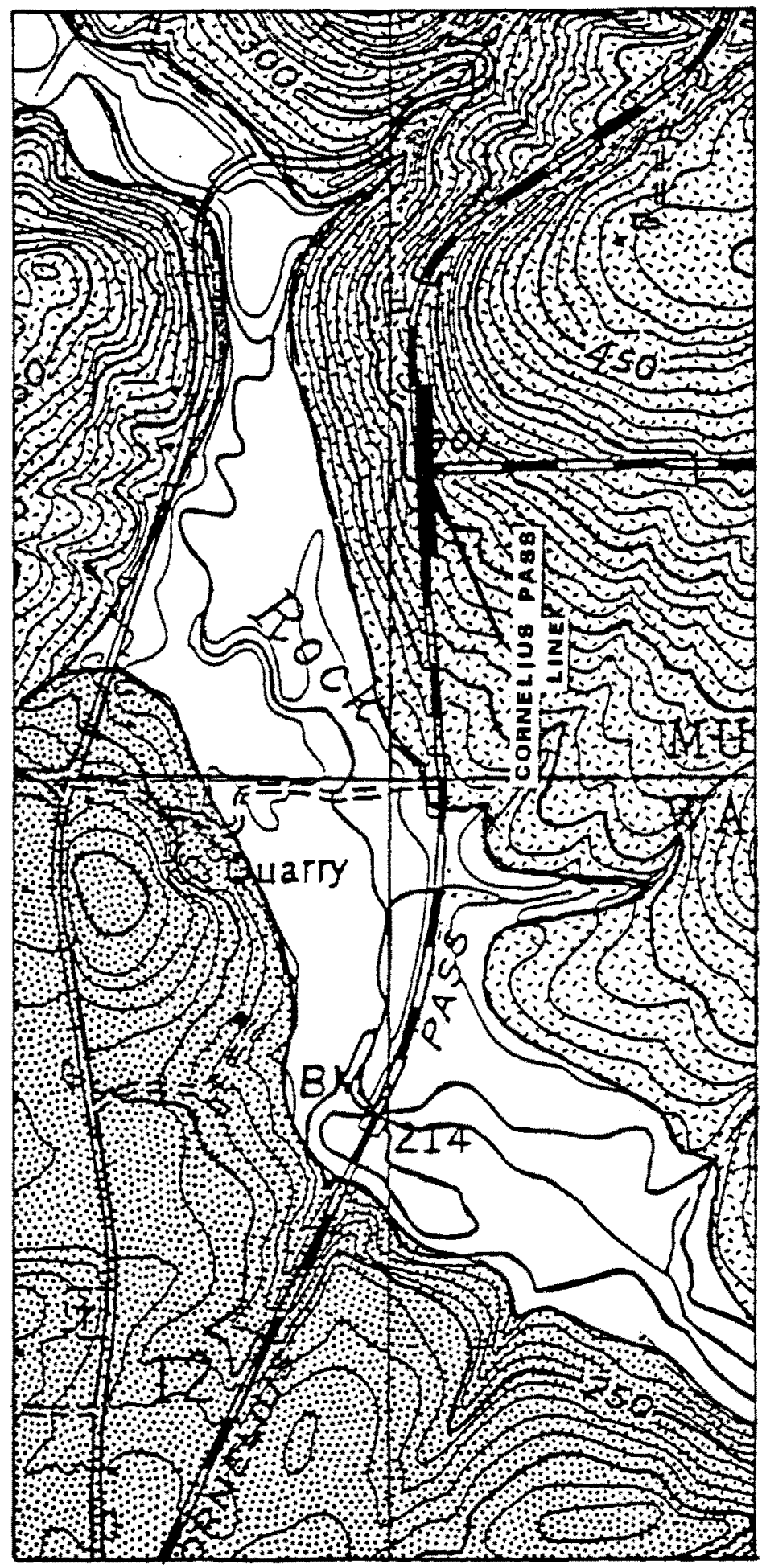

$\left.\begin{array}{l}E \\ \cdots \\ \\ \\ \vdots \\ \vdots \\ 0\end{array}\right]$

$-\infty$

ก)

$r$

os

01

을

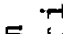

E

I

.

i)

(5)

- 1 .

$\rightarrow 4$

E

0

$+2$

$\checkmark$

ब

4

07

$\rightarrow 0$

$0 \stackrel{9}{7}$

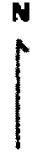

U

0

凹

2

.

$\rightarrow-1$

(1)

C

$4 \pi$

0

(I)

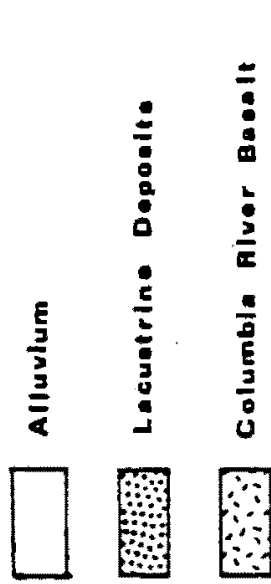




\section{PREVIOUS WORK}

Regional studies of the geology of the Tualatin Valley have previously been published by Warren, Norbisrath, and Grivetti (1945), Tresher (1942), Trimble (1957, 1963), Hart and Newcomb (1965), and Schlicker and Deacon (1967). The origin of the Willamette Silt deposits on the valley floors has been discussed by Allison (1933, 1935, 1936), Glen (1965), and Bretz (1925, 1928). The petrology and stratigraphy of the Portland Hills Silt was described by Lentz (1977). Lowry and Baldwin (1952), Theisen (1958), and Trimble (1963) discussed the genesis of the Upland Silt in the Tualatin Mountains. The subsurface geology of the Tualatin basin has been described by Newton (1969). Van Atta (1985) discussed the stratigraphic relationship between the Scappoose Formation and the Columbia River basalt. Structural contour maps illustrating the top of the Columbia River basalt in the Tualatin Valley and surrounding areas have been prepared by Benson and Donovan (1974) and Schlicker and Deacon (1967).

The existence of several faults in and around the Tualatin Mountains has been proposed by various authors. Johnson and others (1977) and Beeson and others (1976) noted offset Columbia River basalt flows and gravity anomalies along the Portland Hills fault on the eastern edge of the Tualatin Mountains. Basillie and Benson (1971) and Beeson and others (1976) also cited topographic evidence for the Portland Hills fault. Gravity studies by Perttu (1980) and Jones (1977) could be used as evidence for the fault. Earthquake epicenters related to postulated faults in the Portland area were noted by Couch and Lowell 
(1971) and Schlicker and others (1964). Historic earthquake epicenter locations near the Tualatin Mountains are shown in Figure 7 . Schmela (1971) and Anderson (1978) studied the extension of the Portland Hills fault trend into the Clackamas River drainage. The trend of the Portland Hills fault to the northwest was examined by Haas (1983).

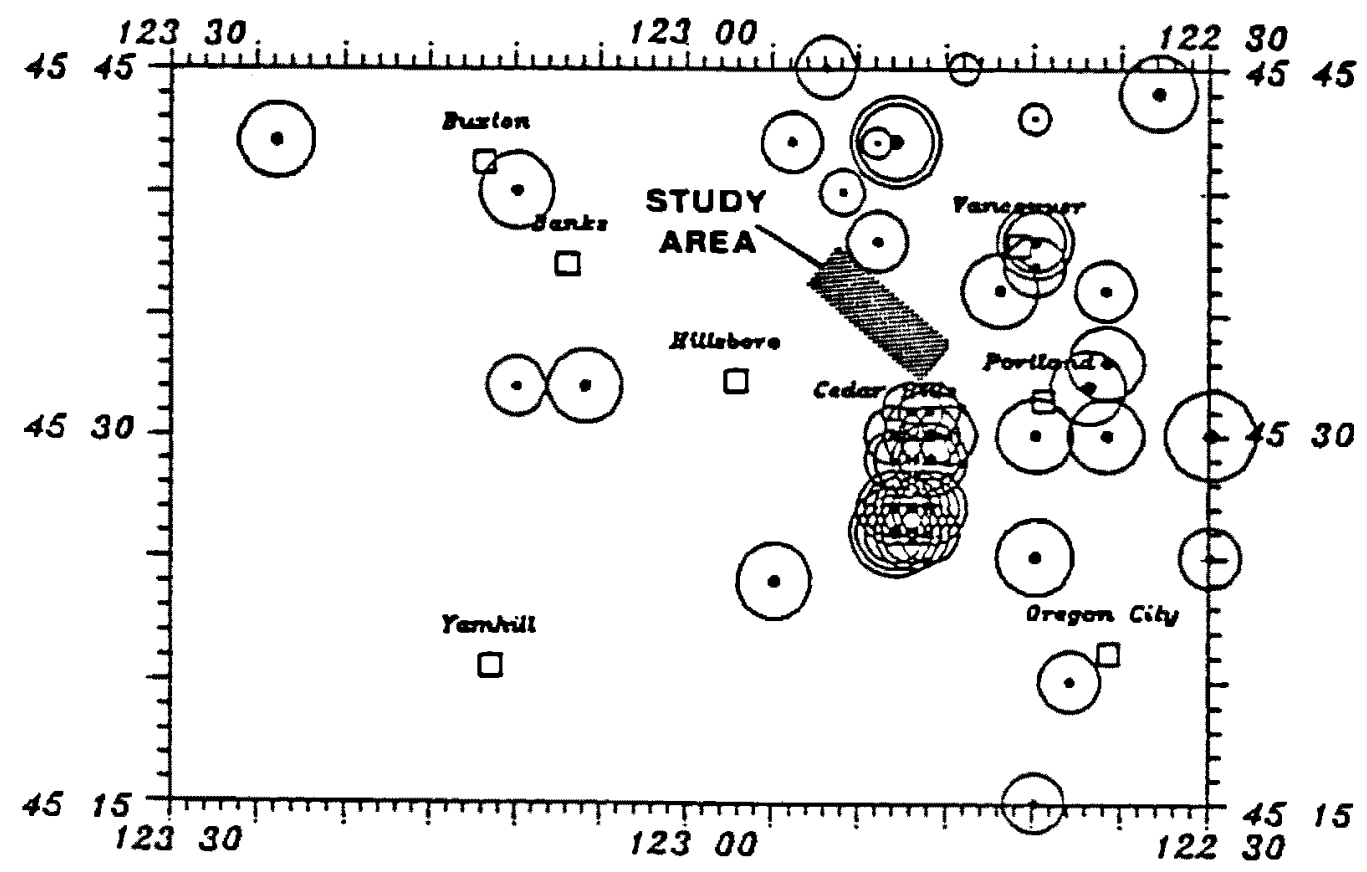

magnitude scale

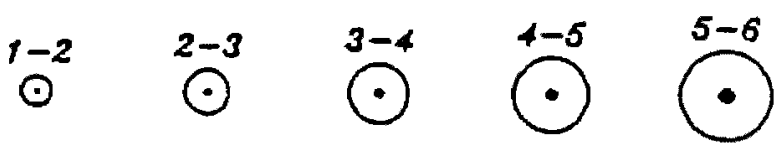

Figure 7. Historic earthquake epicenter locations near the Tualatin Valley. (From Johnson, 1987). 


\section{GEOLOGIC SETTING}

\section{STRATIGRAPHY}

A stratigraphic column of the formations in the study area is shown in Figure 8 . The following description is based primarily on the work of Schlicker and Deacon (1967), Trimble (1963), and Newton (1969).

The Scappoose Formation, late 01igocene to early Miocene in age, is the oldest unit exposed in the study area. The formation, shallow marine in origin, is composed of fossiliferous, tuffaceous, arkosic sandstone, siltstone, and mudstone with local conglomeratic lenses of granule and peasized gravel (Trimble, 1963). The loosely compacted sediments are highly susceptible to alteration and weathering.

Exposures of the Scappoose Formation within the Tualatin Valley are very limited, occurring mainly along the western margin of the valley. Many of these outcrops are parts of landslide complexes, and therefore are not in place (Trimble, 1963). Several exposures of the Scappoose Formation that are presumed to be in place have been mapped in the St. Helens Quadrangle, 15 - 20 kilometers northwest of the study area.

The sedimentary unit in the Bonny Slope area (T1N, RlW, Sec, 26 and 27) that was mapped as Sandy River mudstone by Trimble (1963), and Troutdale Formation by Schicker and Deacon (1967), has more recently been interpreted as the Scappoose Formation (Thoms, pers. com., 1987). Marine fossils were collected in a housing excavation although no 


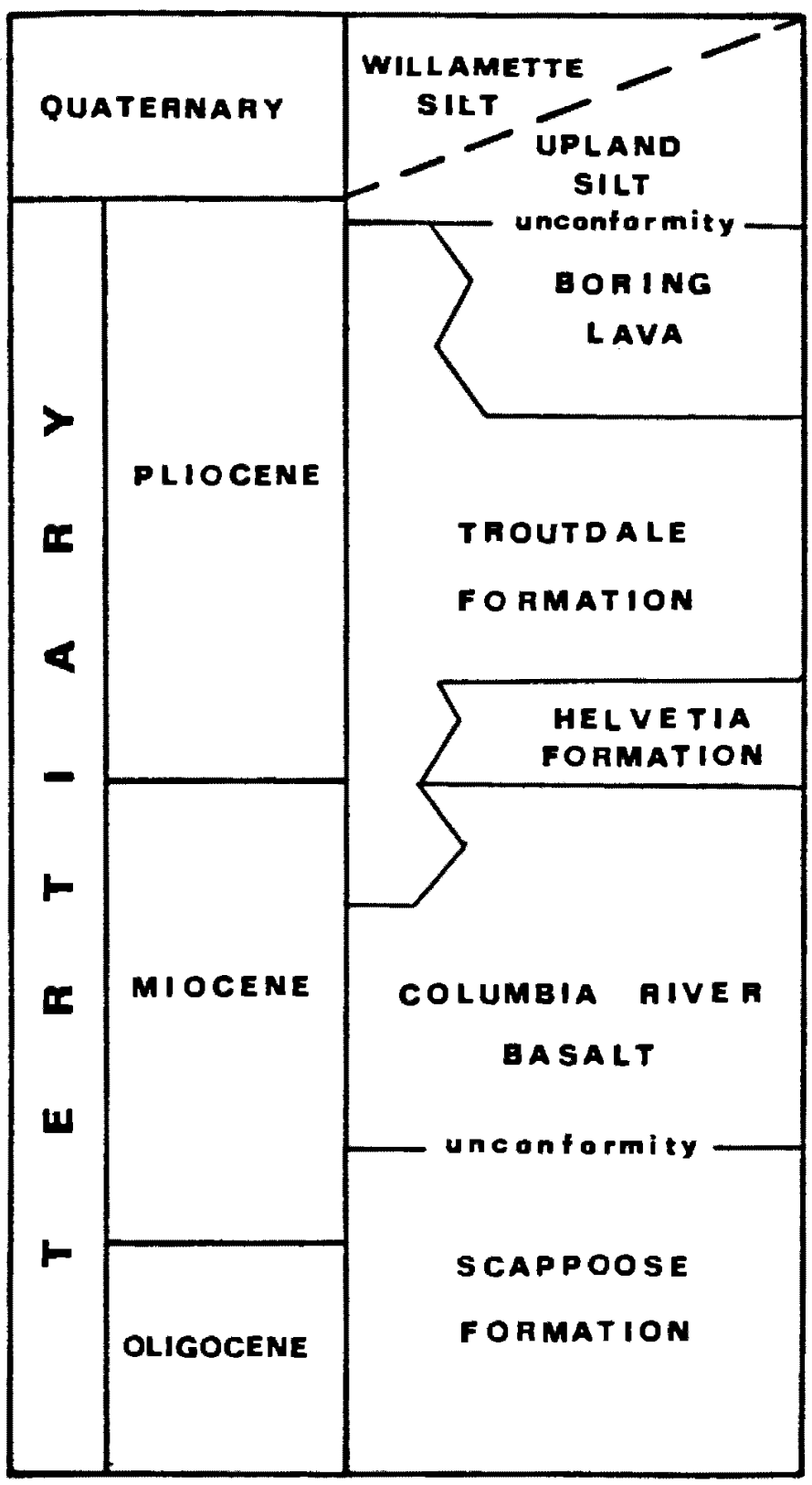

Figure 8. Formations in the study area. (From Trimble, 1963; Schlicker and Deacon, 1967; and Newton, 1969). 
outcroppings of the Scappoose Formation have been found in this area. This exposed "window" of the Scappoose Formation, surrounded by Columbia River basalt, may be the result of faulting or a paleotopographic high during the deposition of the Columbia River basalt. Van Atta (1985) notes that the thickness of both the Scappoose Formation and the Columbia River basalt varies widely indicating that both were deposited over a paleotopography with a relief up to 245 meters.

The Miocene Columbia River basalt unconformably overlies the Scappoose Formation. This unconformity is an eroded surface of high relief (Trimble, 1963). The Columbia River basalt forms the bedrock of the Tualatin Mountains and underlies the entire Tualatin Valley at depths ranging from a few meters to a maximum of about 500 meters (Schlicker and Deacon, 1967; Hammond, 1974; Trimble, 1963). Columbia River basalt in the Tualatin Valley is included in the Grande Ronde Formation (Beeson, pers. com., 1987).

Exposures of the basalt are limited to the margins of the Tualatin Valley with the exception of outcrops around Bull and Cooper Mountains. The formation is composed of a series of lava flows that commonly range in thickness from 10 to 20 meters and are vesicular to scoriaceous in their flow margins. The unweathered surfaces are brownish gray to dark blue-gray, dense, and finely crystalline. The flows commonly show joint systems that range in character from columnar to platy. The basalt exposures are mostly light gray to reddish brown, crumbly, and highly altered to clay minerals due to partial or complete weathering of the rock (Schlicker and Deacon, 1967).

The Helvetia Formation, early Pliocene in age, rests unconform- 
ably upon the Columbia River basalt. The poorly indurated sedimentary deposits generally consist of weathered, reddish brown and light brown pebbly sand, silt, and clay. The formation occurs around almost the entire periphery of the Tualatin Valley and is always found directly above the weathered surface of the Columbia River basalt, extending up the valley slopes to elevations ranging from 50 to 300 meters (Schlicker and Deacon, 1967).

The middle Miocene to Pliocene fluvial deposits of the Troutdale Formation unconformably overlie the Columbia River basalt and makes up most of the sedimentary fill in the Tualatin Valley. The formation consists of poorly indurated gray to brown silt and clay, mottled, yellow to reddish brown silty sand, and occasional pebble conglomerate beds. Data from water wells indicate that the Troutdale reaches its maximum thickness of about 500 meters in the center of the Tualatin Valley near Hillsboro and tapers to a thin edge where it pinches out on the slopes of the surrounding hills (Schlicker and Deacon, 1967).

The Boring Lavas, late Pliocene to early Pleistocene in age, occurs as rounded hills which are found throughout the greater Portland - Vancouver area (Allen, 1975). The hills represent volcanic vents that erupted primarily high-alumina basaltic lava flows (Tolan and Beeson, 1984). The light gray to nearly black basalt is characterized by blocky or columnar jointing (Schlicker and Deacon, 1967). Spheroidal weathering is common, and in some locations the basalt has been weathered to a red clayey soil to depths of 5 meters or more (Trimble, 1963). The Boring Lava cones along the southwestern edge of the Tualatin Mountains are almost totaly covered by a veneer of upland 
loessal silt which ranges in thickness from less than one to more than ten meters (Schlicker and Deacon, 1967).

Quaternary sedimentary deposits cover at least fifty percent of the Tualatin Valley. Schlicker and Deacon (1967) have divided these deposits into two formations, Upland silt and Willamette silt. The Upland silt occurs at elevations above 75 meters and is characterized by massive yellow-brown sandy silt and clayey silt with occasional well rounded basalt pebbles. The loessal deposits mantle the ridges, spurs, and flatter areas of the Tualatin Mountains and range in thickness from one to fifteen meters (Schlicker and Deacon, 1967). The Willamette silt occurs in the lower elevations of the valley and is characterized by bedded silt and fine sand with occasional layers of clay, lenses of pebbly sand, and scattered granite and quartzite cobbles. The deposits are about 15 meters thick near Hillsboro and gradually thin toward the margins of the valley (Schlicker and Deacon, 1967).

STRUCTURE AND TECTONICS

The Tualatin Valley is a fairly well defined elliptical basin centered at Hillsboro, with a major axis trending roughly $N 65^{\circ} \mathrm{W}$ (Hammond and others, 1974). The basin is filled with fluvial and lacustrine Troutdale sediments and Willamette silt. The valley is bordered on the northeast by the Tualatin Mountains (Portland Hills) which have been interpreted as a faulted, northwest trending asymmetrical anticline (Balsillie and Benson, 1971; Beeson and others, 1985). The Tualatin Mountains are bordered on the east by the Portland basin which 
has been interpreted as a pull apart basin genetically related to the Portland Hills - Clackamas River structural zone (Beeson and others, 1985). The Portland Hills - Clackamas River structural zone is presumed to be a northwest trending wrench fault zone which includes the Tualatin Mountains (Beeson and others, 1985). Several faults and folds have been proposed in the Tualatin Valley (Hart and Newcomb, 1965; Schlicker and Deacon, 1967; Trimble, 1963; Johnson, 1976; Hammond and others, 1974; Beeson, and others, 1976), although the locations and the amount of offset are uncertain. Boring Lavas, having been erupted through the Columbia River basalt, may define zones of fracture of faulting in the Columbia River basalt (Beeson and others, 1976). The Columbia River basalt beneath the Tualatin Valley may be broken into separate blocks which have been deformed independently (Hammond and others, 1974).

The formations in the Tualatin Valley are included in the upper part of a 7500 meter sequence of volcanic and sedimentary rocks in western Oregon (Snavely and Wagner, 1964). The basement rock in this sequence are the 3000-6100 meter thick (Newton, 1969) Tillamook Volcanics which are equivalent to the Siletz River Volcanics in the central Oregon Coast Range. These submarine pillow basalts and breccias are thought to be oceanic crust formed at a spreading ridge and accreted onto the continent when the subduction zone moved fron east of the Coast Range to the present continental margin (Snavely and others, 1980). Following the westward jump of the subduction zone, the region could be characterized as a large depositional basin. By late Eocene, areas of local uplift and volcanism divided the regional basin into 
smaller shallow depositional basins. In the northeastern part of the present Coast Range, Goble Volcanics erupted into a structural downwarp (Newton, 1969) where they are interbedded with marine sedimentary rocks of the Cowlitz Formation. The Oligocene was characterized by sedimentation in the northeast part of the Coast Range and throughout the northern Willamette Valley (Snavely and Wagner, 1963). Pyroclastic volcanism in the ancestral Cascade Range provided large amounts of ash to the marine deposits of the Keasey, Pittsburg Bluff, and Scappoose Formations. Broad uplift during late Oligocene (Snavely and Wagner, 1963) resulted in a westward shift in marine deposition (Kulm and Fowler, 1974) and minor deformation of rocks in the northern Coast Range (Newton and Van Atta, 1976).

The northwest trending Portland Hills - Clackamas River structural zone was active by at least early mid Miocene (Beeson and others, 1976). Movement along the structural zone produced a topographic barrier that affected the distribution of several Columbia River basalt flows. The thinning and termination of units across this zone indicate that tectonic activity was continuous throughout this time interval (Beeson and others, 1985). The right-lateral movement along the structural zone may be related to extension of the basin and range province (Beeson and others, 1976). The structural zone may also be related to north - south compression caused by the possible subduction of the Farallon plate although the location of the subduction zone is not known (Dehlinger, 1969; Dehlinger and Couch, 1969; Crosson, 1972). 


\section{METHODS OF INVESTIGATION}

\section{INTRODUCTION}

Seismic refraction lines were run along roads to investigate the near surface ( 0 to 50 meters deep) geologic structure. Cross sections illustrating the depth and dip of refracting layers can be modeled from the field data which is plotted a time versus distance graphs. The cross sections and graphs are presented with discussion of individual refraction lines in the results and discussion section.

Locations were chosen for the purpose of detecting Columbia River basalt. The contact of high-velocity basalt underlying low-velocity sediment should be a good refracting horizon. Therefore, lines were set up where Columbia River basalt is thought to occur at or near the surface. Displacement along the surface of the basalt should be detectable through the methods used in this study.

\section{PROCEDURES}

\section{Field Techniques}

Field work was completed between the months of June and August, 1986. A seismic refraction thumper, on loan from Oregon State University School of Oceanography was used as the energy source. The thumper consists of an electric winch which is used to lift a 300 or 500 pound weight. The weight was dropped a distance of about 3.2 meters onto a steel plate on the ground. A twelve channel refraction seismograph was 
used to collect the seismic records.

The seismic lines were run along the edges of roads near locations where Trimble (1963) mapped the contact between the Columbia River basalt and overlying sedimentary fill (See Figure 2). Other factors influencing the choice of line locations were accessibility, straightness of the road, and amount of traffic. Because of the large amount of seismic "noise" caused by a passing vehicle, heavily traveled roads had to be avoided. Refraction lines were also run near intersections of roads in order to collect data in perpendicular directions to get the true dip of discontinuities.

The apparent dip of a refracting layer can be determined if the seismic profile is reversed (Telford and others, 1976). To "reverse" a profile, the energy source was dropped at both ends of the line. Thus, two sets of data, recorded in opposite directions, were collected for each line. The refraction data is presented in Apendix A.

Most of the lines were set up with a maximum shot to receiver spacing of 90 meters. The geophones were spaced a distance of 10 meters apart. The first receiver was spaced 5 meters from the shot in order to record the direct arrival velocity by at least two geophones. Whenever possible, two 90 meter lines were run end to end and an extended shot was dropped at the far end of one line to make an effective 180 meter line. The greater shot to receiver distance allows for the detection of deeper layers (Mota, 1954). A typical double line layout is shown in Figure 9. 


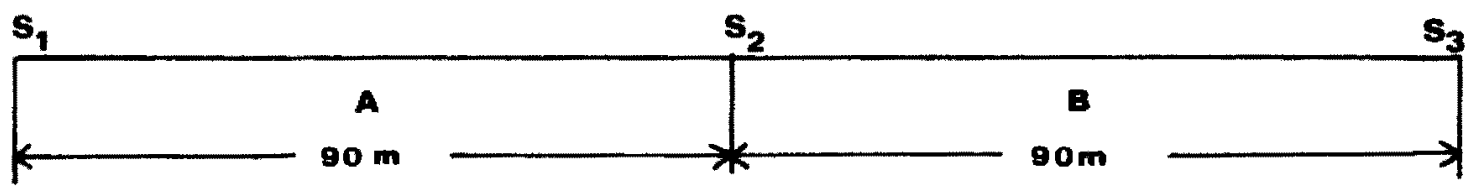

Figure 9. Typical refraction line layout.

For example, data was collected for line A with a 300 pound weight dropped at $\mathrm{S}_{1}$ and $\mathrm{S}_{2}$. Data was then collected on line A with a 500 pound weight dropped at $S$. The larger weight was needed for the 3 extended shot because the seismic signal was attenuated at greater distances. The geophones were then spread out over line B with a 300 pound weight dropped at $S$ and $S$ and a 500 pound weight dropped at $S$. This produced a 180 meter seismic line with double coverage.

\section{Data Reduction}

The signal from each geophone was recorded as a trace of light on photographic paper. An example of a field record is shown in Figure 10. The first seismic wave to be detected after the shot was marked directly on the paper for each trace. The mark on each trace is taken to be the first break for the corresponding geophone. The mark on the time break geophone trace is the time that the weight hit the ground. The first arrival time for each geophone is the time elapsed between the mark on the time break trace and the mark on the geophone trace. The distance between the horizontal lines on the field record represents .01 seconds. The first arrival time for each geophone is then plotted against distance from the shot. Reversed profiles were plotted 


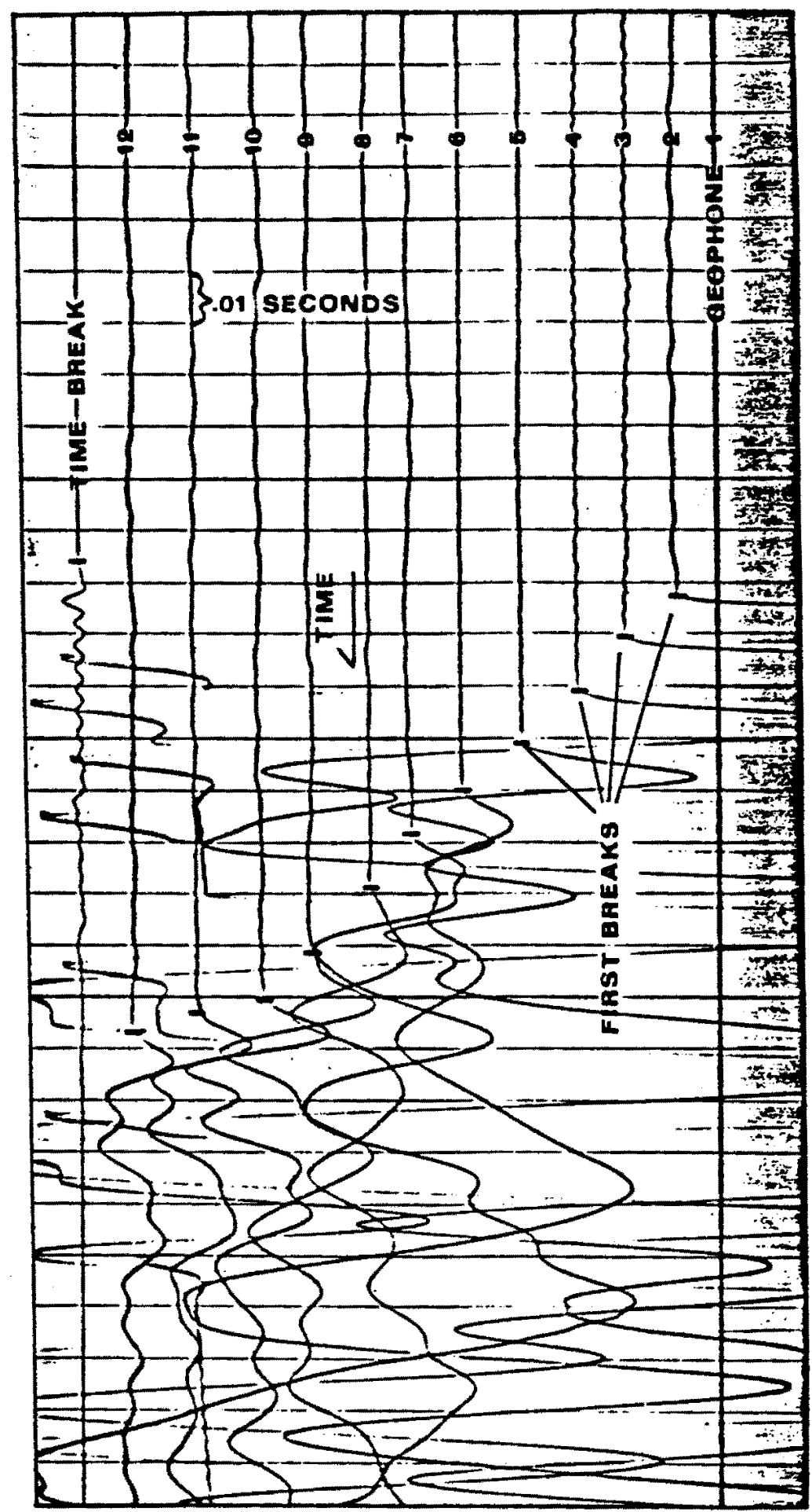

Figure 10. Example of a seismic field record. 
on the same graph. Figure 12 shows an example.

The inverse of the slope of a line fit to points on a time versus distance graph represents an apparent velocity. A FORTRAN program was used to fit a line to the points on a time-distance graph by the least squares method. C. B. Reynolds wrote the program which is listed in Appendix B. The program calculates an apparent velocity for a segment of a profile that the operator has chosen to represent a refracting surface. Corresponding segments from reversed profiles are then used to calculate "true velocities", depths, and dips of refracting layers. Standard formulas for determining these values are given in Ewing and others (1939), Nettleton (1940), Mota (1954), Dobrin (1960), and Heiland (1968). The formulas used are shown in Appendix A. Using the formulas given in Mota (1954), a FORTRAN program, entitled "Layers", was written to calculate actual velocities, dips, and depths for a twolayer and three-layer model. The program listing is given in Appendix B.

\section{Equipment Used}

SIE recording amplifier, model RA-44, 12 channels.

SIE recording oscillograph, model $\mathrm{R}-4$.

Mark Products $7.5 \mathrm{~Hz}$ geophones.

Thumper trailer with 300 pound and 500 pound weights, loaned by Oregon State University, School of Oceanography. 


\section{GEOPHYSICAL MODELING}

\section{SEISMIC REFRACTION}

Several principles make the use of seismic refraction possible. The first of these is that sound waves travel through earth materials with a definite velocity and along a definite path. The velocity depends strongly upon the nature of the materials, particularly upon the degree of consolidation. Fermat's principle states that the sound waves will follow the path which requires the least amount of time from source to receiver (Dix, 1941). Since travel time equals distance divided by velocity, a longer path which includes a high velocity segment may require less time than the direct path.

The theory making seismic refraction possible can be illustrated by a horizontal, two-layer mode1. Figure 11 shows four of the many seismic ray paths that are produced at the time of impact. Ray $D$ is a direct wave that travels at velocity $\mathrm{V}$. Ray $\mathrm{C}$ will be reflected at 1 the discontinuity and return to the surface. Ray $\mathrm{C}$ also travels its entire path at velocity $\mathrm{V}$. Rays $\mathrm{A}$ and $\mathrm{B}$ are both refracted at the discontinuity according to Snell's Law. This states that a seismic ray wil1 trave1 in a straight line though any material which has a constant velocity, but that it will be bent when it passes through a discontinuity (Telford and others, 1976). Rays such as ray $A$ are bent at the discontinuity but will not return to the surface. Energy arriving at the discontinuity at the critical angle (I ), such as ray $B$, will 


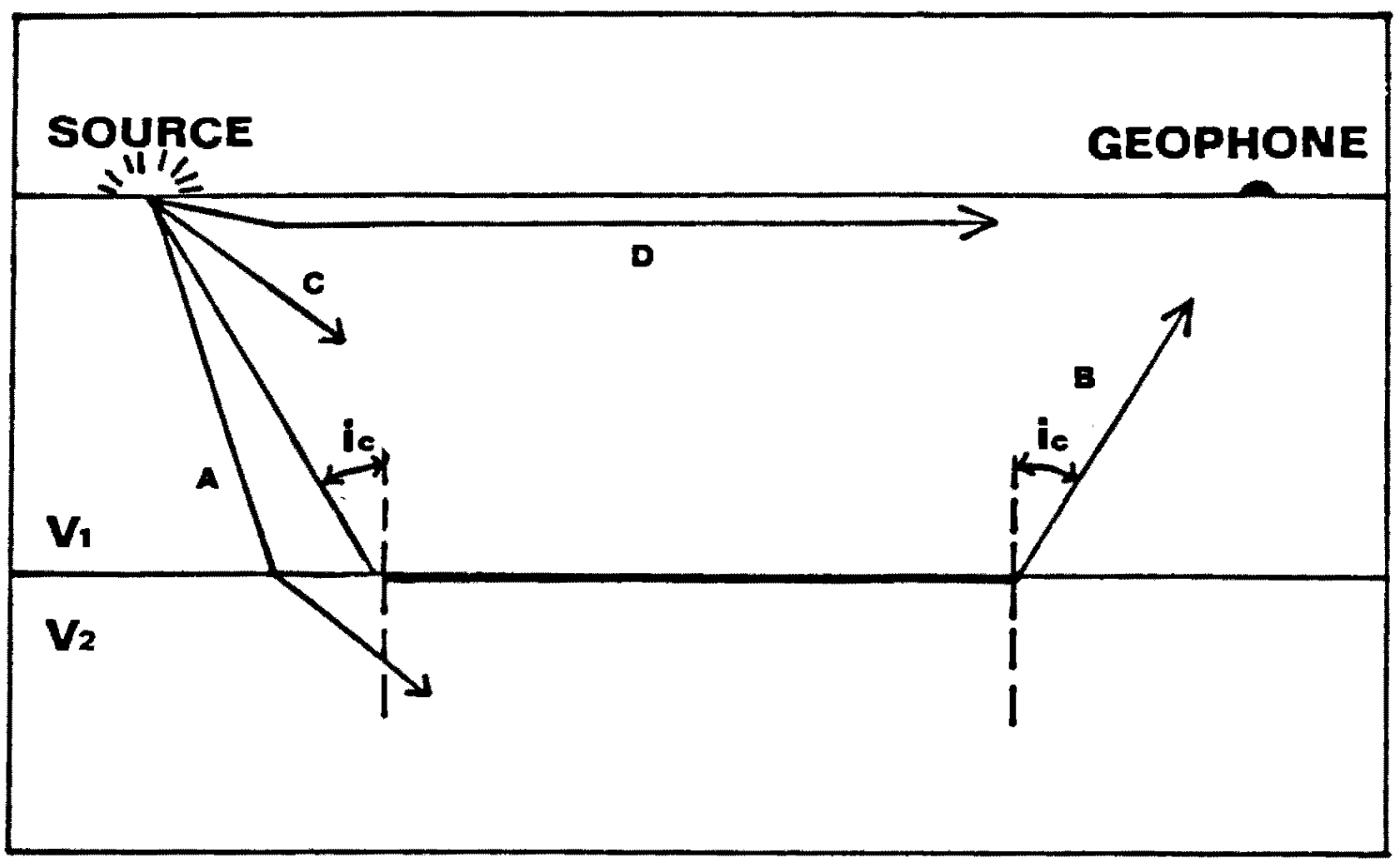

Figure 11. Diagram showing paths of seismic waves leaving source at time of impact. (Modified from Laster, 1967).

travel along the discontinuity at velocity $V_{2}$. This creates a disturbance in the upper medium producing waves which travel back toward the surface at the critical angle. The sine of the critical angle equals the ratio of the velocities of the materials on each side of the discontinuity ( $\operatorname{Sin} I=V / V)$. Since ray path $B$ contains a high C 112

velocity segment $\left(V_{2}>V_{1}\right)$, it will be the first arrival at geophones spaced far enough from the source. The travel time from source to receiver gives information on the velocity and general structure of the materials beneath the surface (See formulas in Appendix $A$ ).

Several assumptions are made during the interpretation of seismic refraction data. 1) The velocity of each successively deeper geologic 
layer is greater than the layer above it. 2) Each layer is isotropic and has a constant velocity within its boundaries. 3) Each layer is sufficiently thick to be detected by refraction. 4) The boundary between two layers can be approximated by a plane (Dix, 1939a; Dix, 1939b; Musgrave, 1967).

The first assumption is neccessary because energy travelling from a faster to a slower layer will be refracted toward the normal in the slower layer. Thus a low velocity layer beneath a high velocity layer will not be a first arrival on the time-distance plot, and the next high velocity layer will appear deeper than it really is. In this study the deeper, more compacted sediments are less porous and will have a higher velocity than the shallower ones, and near-surface sediments will have a lower velocity than the underlying basalt.

Constant velocity within each layer is of ten not an accurate assumption. Compacted sediments with a linear increase in depth will show on the time-distance plot as a curved line (Rockwell, 1967). Usually the average velocity within the interval being investigated is used and provides an adequate approximation of the actual conditions. Velocity may also vary laterally within a layer but will usually be averaged out over the length of the refraction line (Dobrin, 1960; Redpath, 1973). Other factors influencing the velocity within a layer include the presence of water which will increase the velocity and joints or fractures which will decrease the velocity (Dobrin, 1960). Many, if not most, interfaces between geologic layers are nonplanar. Surface irregularities in the interfaces will affect the transmission of seismic energy. Usually the first arrival times will 
be scattered about a line which can be taken as the average velocity on the time-distance plot. High frequency energy (short wavelength) is absorbed faster than low frequency energy and is scattered more by irregulariaties as distance from the source increases. This may result in less distinct arrivals at greater distances from the source (Redpath, 1973). A gap of no arrivals on the seismic record may indicate the presence of a large irregularity in the refracting horizon (Dix, 1952).

Most errors in seismic refraction interpretation result from three general causes: 1) incorrect reading of the data, 2) incorrect assumptions, 3) incorrect geologic interpretation (Northwood, 1967). Incorrect picking of first breaks leads to errors in depth and dip calculations, and is especially likely when velocity contrasts between two successive layers are not very great or there is a large amount of background noise. Incorrect assumptions can be minimized by using all available data on the local geology and checking interpretations against bore hole data.

The depths to the refracting horizons shown on the cross sections are not exact, and at best are close approximations. The depth values cover a range, resulting from different velocity readings in opposite directions for each layer and variations in velocity along the line. The values shown on the cross sections are within the calculated range and represent a simple geologic interpretation that is consistant with the data. Similarly, locations of faults and vertical offsets are shown within their possible range (For example, see Figure 12).

The remainder of this chapter is used for discussion and presen- 
tation of the data for each refraction line. The lines are presented in order from southeast to northwest through the study area. The time versus distance plot and schematic cross section is included with the discussion for each line.

\section{RESULTS AND DISCUSSION}

\section{Thompson Road Line}

The Thompson Road line is 90 meters long. This location (Shown in Figure 3), was chosen for the purpose of determining the depth and dip of the upper surface of the Columbia River basalt. Columbia River basalt has been mapped at this location (Trimble, 1963; Schlicker and Deacon, 1967; and Newcomb, 1967), although outcrops could not be found in the field. The surface along this line consists of a clayey soil with widely scattered basalt cobbles and boulders. The length of the line was limited to 90 meters because NW Thompson Road has no straight segments longer than about 100 meters in this vicinity.

Two velocity layers were observered in the time-distance curve (Figure 12). The surface layer has an average velocity of about 700 $\mathrm{m} / \mathrm{s}$. The second layer has a velocity of $1475 \mathrm{~m} / \mathrm{s}$. The surface of the first refracting layer has been been modeled to include a fault. The fault is shown schematically on the cross section as a vertical displacement. The time-distance curve indicates that the southeast side of the fault has moved up relative to the northwest side. The throw of the fault was calculated to be about 6 meters.

The surface of the second layer dips between 0 and 5 degrees to the northwest. The depth to the first refracting layer below the 


\section{THOMPSON ROAD LINE}
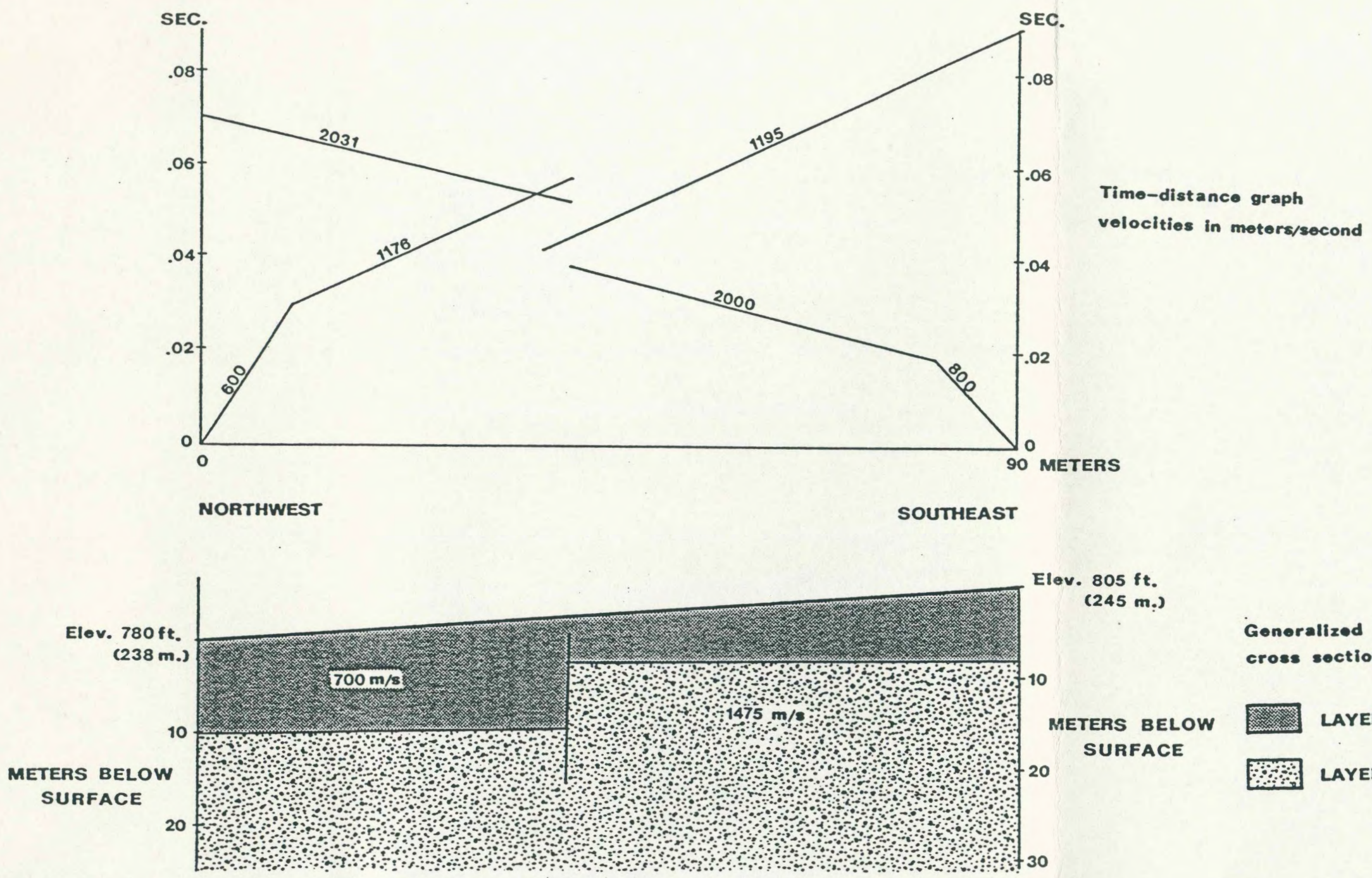

Elev. $805 \mathrm{ft}$.

(245 m:)

10

METERS BELOW

SURFACE

\section{Generalized}

cross section

Figure 12. Thompson Road refraction line, timedistance plot and generalized cross section. 
northwest shot point is between 8 and 11 meters. The depth to the first refracting layer below the southeast shot point is between 6 and 9 meters below the surface.

\section{Bonny Slope Line}

The Bonny Slope line (See Figure 3), 350 meters long, is made up of two segments which have a bend between them of about 45 degrees. Segment one, 170 meters long, was run in an east-west direction. Segment two, 180 meters long, was run at approximately $N 45^{\circ} \mathrm{W}$. Both segments share a common shot point at the curve in NW Laidlaw Road. The location of the Bonny Slope line was chosen to investigate the nature of the contact between the Columbia River basalt and the sedimentary unit that Trimble (1963) has mapped as Sandy River mudstone and Schlicker and Deacon (1967) have called Troutdale Formation. The Bonny Slope line crosses this mapped contact near the middle of the line (See Figure 3).

The time-distance plot and generalized cross section of the Bonny Slope line are illustrated in Figure 13. This line differs from the others in the study in that the seismic signal was rapidly attenuated or possibly refracted downward in the central part of the line. The first breaks for the geophones 140 - 170 meters from the nor thwest shot point could not be picked off the seismic record. The time-distance plot was difficult to model because high velocities (greater than 2000 $\mathrm{m} / \mathrm{s}$ ) were only recorded in the central part of the line.

The time-distance curve for the Bonny Slope line indicates the presence of at least three velocity layers that may be discontinuous. The surface layer has a velocity ranging between 500 and $800 \mathrm{~m} / \mathrm{s}$. 
BONNY SLOPE LINE
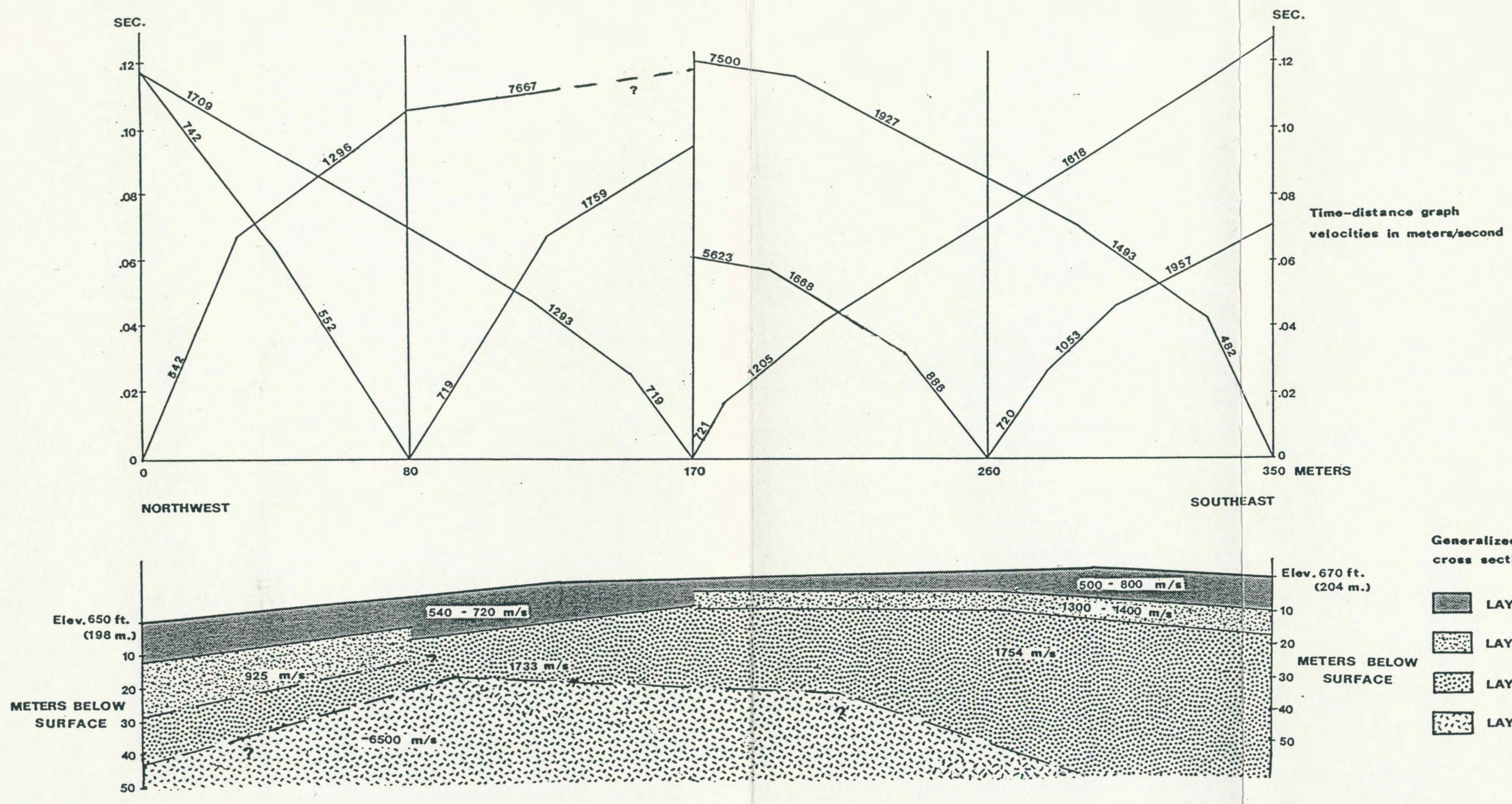
Lower velocities for this layer were recorded on the west end of the line.

The second layer has a velocity ranging between 900 and $1750 \mathrm{~m} / \mathrm{s}$. This layer has been split into two units on the cross section, the upper unit shown as being discontinuous. The lower velocity (1300 $1400 \mathrm{~m} / \mathrm{s}$ ) upper unit of the second layer is better defined on the southeastern half of the line and may be a separate unit above the 1754 $\mathrm{m} / \mathrm{s}$ layer. The $925 \mathrm{~m} / \mathrm{s}$ layer is included on the northwest end of the line in response to the apparent velocity of 742 recorded on the $0-80$ meter segment of the line. The $1733-1754 \mathrm{~m} / \mathrm{s}$ layer is shown to be continuous throughout the line. A velocity in this range was recorded from each shot point.

A forth velocity layer is indicated on the cross section with a velocity of around $6500 \mathrm{~m} / \mathrm{s}$. This high velocity layer was detected only in the central part of the line on the extended shots from each end of the line. The apparent velocity of $5623 \mathrm{~m} / \mathrm{s}$ was also recorded on the 170 - 260 meter segment from the 260 meter shot point. This layer was not encountered on profiles shot from the central shot point (170 meters).

Depths to the first refracting layer were calculated to be between 4 and 13 meters. This layer apparently dips away from the central part of the line between 5 and 10 degrees.

The upper part of the second layer is between 5 and 7 meters thick on the southeastern half of the line. This layer dips between 0 and 5 degrees to the southeast. The thickness of this layer is estimated to be between 0 and 15 meters at the northwest end of the line. 
The lower part of the second layer is shown to be between 13 and 25 meters thick, although these values are at best close approximations. The depth to the high velocity layer in the central part of the line is shown to be between 25 and 40 meters on the cross section. The absence of this unit on either end of the line may indicate that this layer dips away from the central part of the line up to 15 degrees. This layer could also be discontinuous or possibly faulted.

Several of the first arrivals are scattered about a line when plotted on a time versus distance graph. This may indicate the presence of an undulatory refracting surface.

Laidlaw Road Line

A 90 meter line was run along NW Laidlaw Road (See Figure 4). This location was chosen for the purpose of locating the upper surface of the Columbia River basalt sloping into the valley. Equipment problems, traffic noise, and limited space along NW Laidlaw Road resulted in discontinuing this line past 90 meters.

Three velocity layers were interpreted from the time-distance plot (Figure 14). The surface layer was recorded to have a velocity of $573 \mathrm{~m} / \mathrm{s}$. Apparent velocities of 1552 and $1735 \mathrm{~m} / \mathrm{s}$ were recorded for the first refracting layer which has an actual velocity of $1638 \mathrm{~m} / \mathrm{s}$. Several of the phones recorded first breaks that did not fit on a straight line indicating an undulating upper surface on the second layer. A third velocity layer is indicated on the time-distance plot with an apparent velocity of $4800 \mathrm{~m} / \mathrm{s}$. This layer was recorded by the last three phones ( 80 - 90 meters) on the shot at the west end of the line. 


\section{LAIDLAW ROAD LINE}
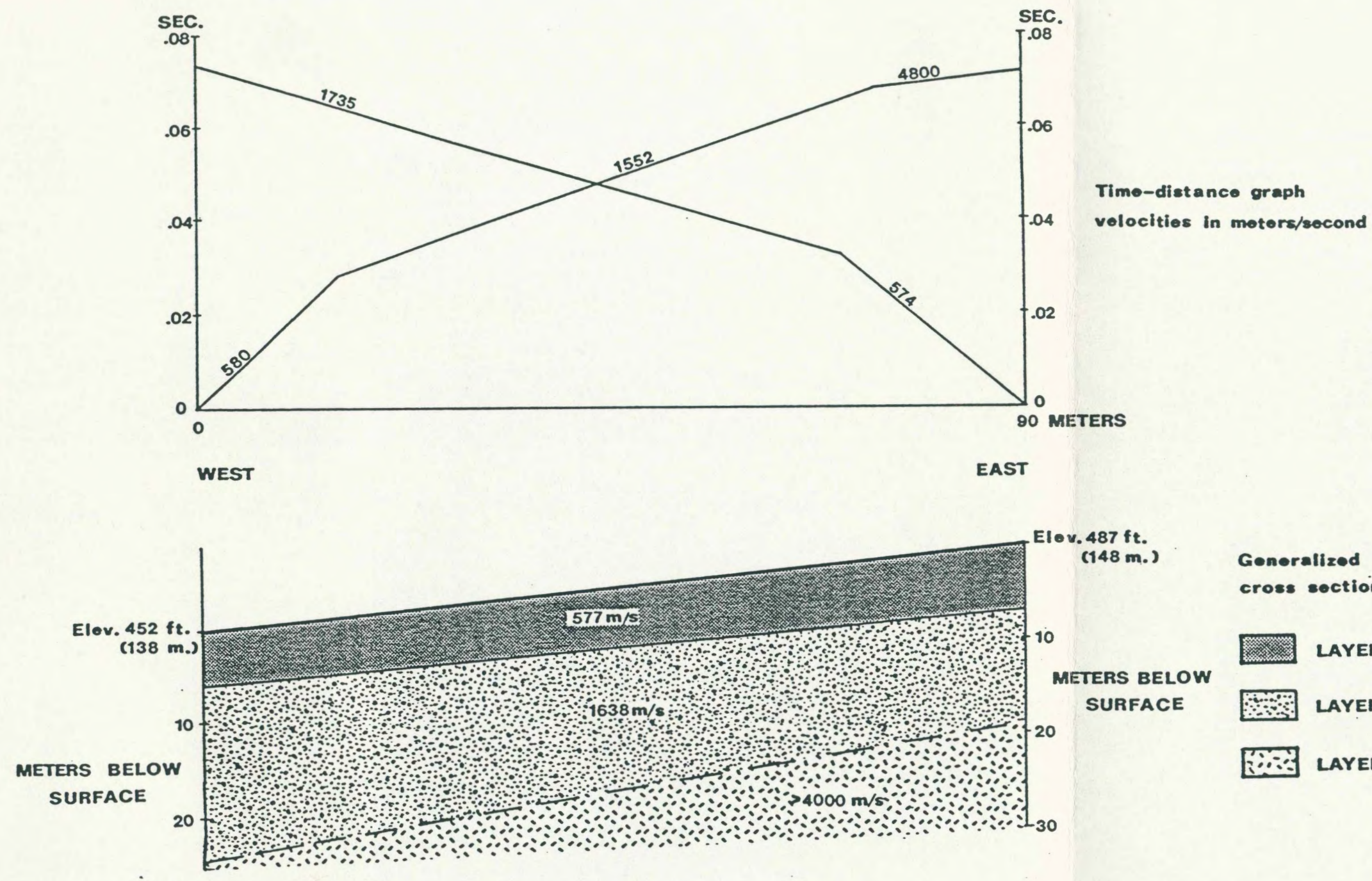

Elov. $487 \mathrm{ft}$.
(148 m.)

Generalized

cross section

10

METERS BELOW

SURFACE

LAYER 1 (vO)
LAYER 2 (V1)
EO: LAYER 3 (V2)

Figure 14. Laidlaw Road refraction line, timedistance plot and generalized cross section. 
The surface of the second layer has an apparent dip of about 5 degrees westward which is roughly parallel to the topography. The upper surface of this layer occurs at a depth of about 6 meters below the west shot point and 7 meters below the east shot point. The third layer was recorded on the east end of the line and is estimated to occur approximately 19 - 25 meters below the surface.

\section{Bronson Creek Line}

The Bronson Creek line, 360 meters, was run under ideal conditions along NW 124th Street (See Figure 4). There was minimal noise and the quality of the seismic signal was good. This line was run roughly perpendicular to the slope of the hill which extends down to Bronson Creek between two Boring Lava cones. The line is run across an area that has been mapped as Columbia River basalt (Trimble,1963), Troutdale Formation (Newton, 1967), and across the contact between the two formations (Schlicker and Deacon, 1967). The lines were run to determine the local thickness of the sediment or "weathered" layer overlying the Columbia River Basalt.

The time-distance plot (Figure 15) is relatively complicated and indicates the presence of at least three velocity layers. The first breaks for most of the phones could be fit directly on straight lines on the time-distance plot which may indicate that the refracting horizons are relatively smooth.

Surface velocities ranged between 500 and $960 \mathrm{~m} / \mathrm{s}$. Higher surface velocities were recorded from the 0 and 360 meter shot points (See Figure 15). Velocities between 500 and $600 \mathrm{~m} / \mathrm{s}$ were recorded for each of the other shot points on the line. 


\section{BRONSON CREEK LINE}
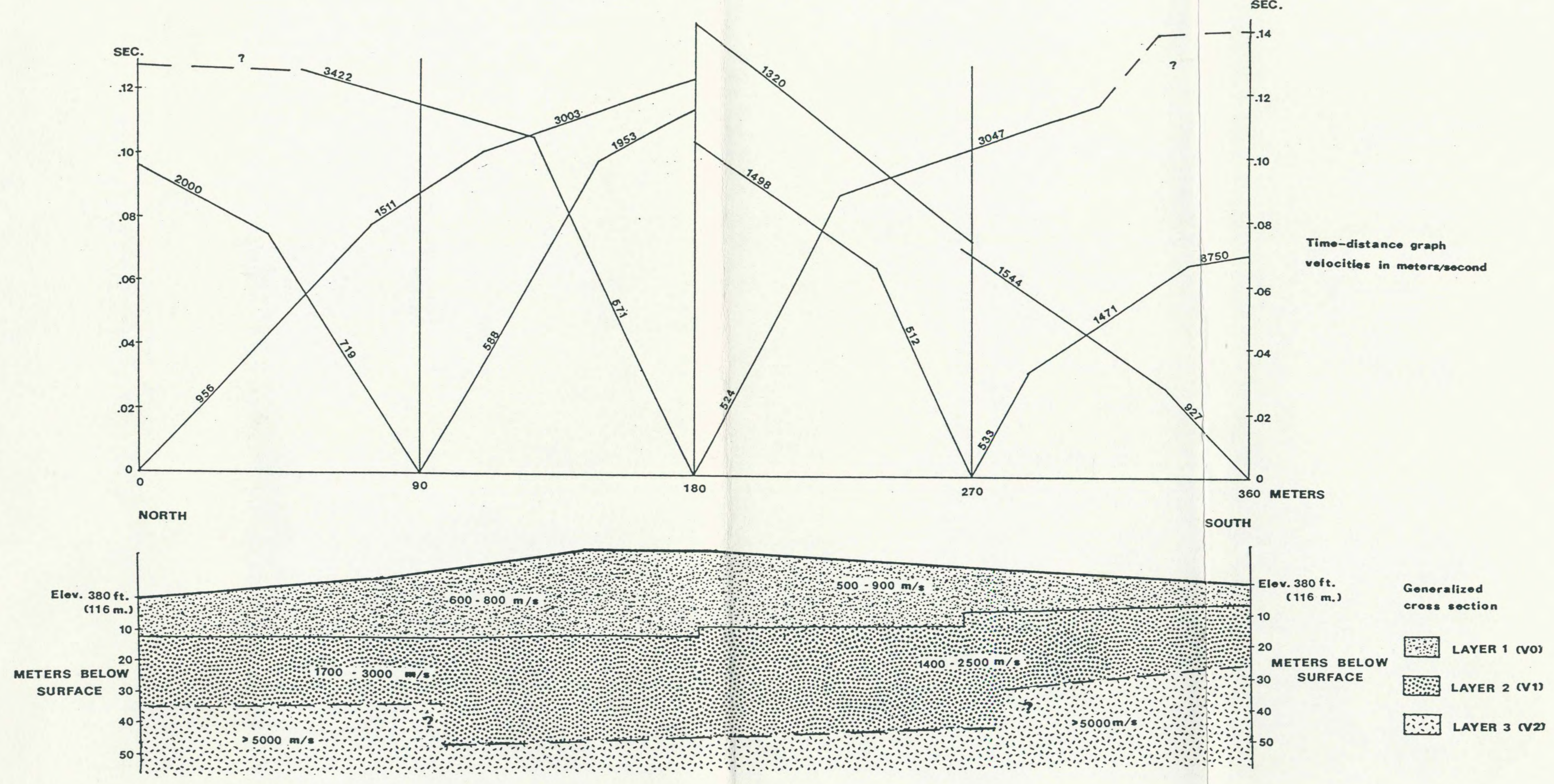

Figure 15. Bronson Creek refraction line, time-distance plot and generalized cross section. 
Apparent velocities of the second layer ranged between 1300 and $3500 \mathrm{~m} / \mathrm{s}$, averaging around $1500 \mathrm{~m} / \mathrm{s}$. The lack of symmetry between the reversed profiles on the time-distance plot (See Figure 15) may indicate that the second layer is broken up into separate blocks. Calculated true velocities for the second layer ranged between 1400 and 3000 $\mathrm{m} / \mathrm{s}$. The higher velocities were recorded in the central part of the line, which is opposite of what was recorded for the surface layer. The wide range of velocities may indicate that the second layer has several different velocity zones which may be related to degree of consolidation of the rock.

The time-distance plot indicates the presence of a third layer which was detected on each end of the line. An apparent velocity of $10,000+\mathrm{m} / \mathrm{s}$ was recorded in each direction by distant geophones from the central shot point. A velocity of $8750 \mathrm{~m} / \mathrm{s}$ was also recorded by the last four geophones ( 340 - 360 meters) on the 270 meter shot. The high apparent velocities may indicate that the third layer is steeply dipping or possibly faulted.

A simplified interpretation of the time-distance plot is presented in the cross section in Figure 15. Depths to the first refracting layer range from $6-12$ meters at the end shot points to $19-27$ meters in the central part of the line. The surface of this refracting layer is nearly horizontal but becomes deeper in the central part of the line because of the surface topography. The depth to the second refracting layer is estimated to be between 25 and 60 meters.

Springville Lane Line 1

Springville Lane line one, 180 meters, was run in an east-west 
direction perpendicular to Springville Lane line two. The shot point at the east end of line one is at the same location as the central shot point on line two. Trimble (1963) mapped the contact between Columbia River basalt and Boring Lava near this location (See Figure 4). This area was mapped as Upland silt by Schlicker and Deacon (1967). The lines were run for the purpose of determining the local thickness of surface sediment and the dip of the basalt.

The records were of good quality and interpretation of the timedistance plot (Figure 16) was relatively straight forward with the exception of the profile that was shot from the west end of the line. The seismic energy was highly attenuated on the eastern end of the line and there was difficulty picking first breaks past 130 meters (from the west end of the line).

Three layers are interpreted from the time-distance plot. The surface velocity was recorded to be $417 \mathrm{~m} / \mathrm{s}$ on three of the four profiles. Apparent velocities for the second layer range from 1105 to $1522 \mathrm{~m} / \mathrm{s}$, averaging around $1350 \mathrm{~m} / \mathrm{s}$. The first breaks were scattered about a line on the time-distance plot indicating an undulating upper surface on the second layer. The profile shot from the west end is broken up into apparent velocities of 1105,2325 , and $2551 \mathrm{~m} / \mathrm{s}$ on the time-distance plot (See Figure 16). These segments do not correlate with the corresponding velocity segments from the otter shot points and may represent either the second or third velocity layer. The value of $1105 \mathrm{~m} / \mathrm{s}$ was used for the depth and dip calculations for the second layer because of its similarity to the velocites from the other shot points. The apparent velocities of 2326 and $2551 \mathrm{~m} / \mathrm{s}$ were interpreted 


\section{SPRINGVILLE LANE LINE}
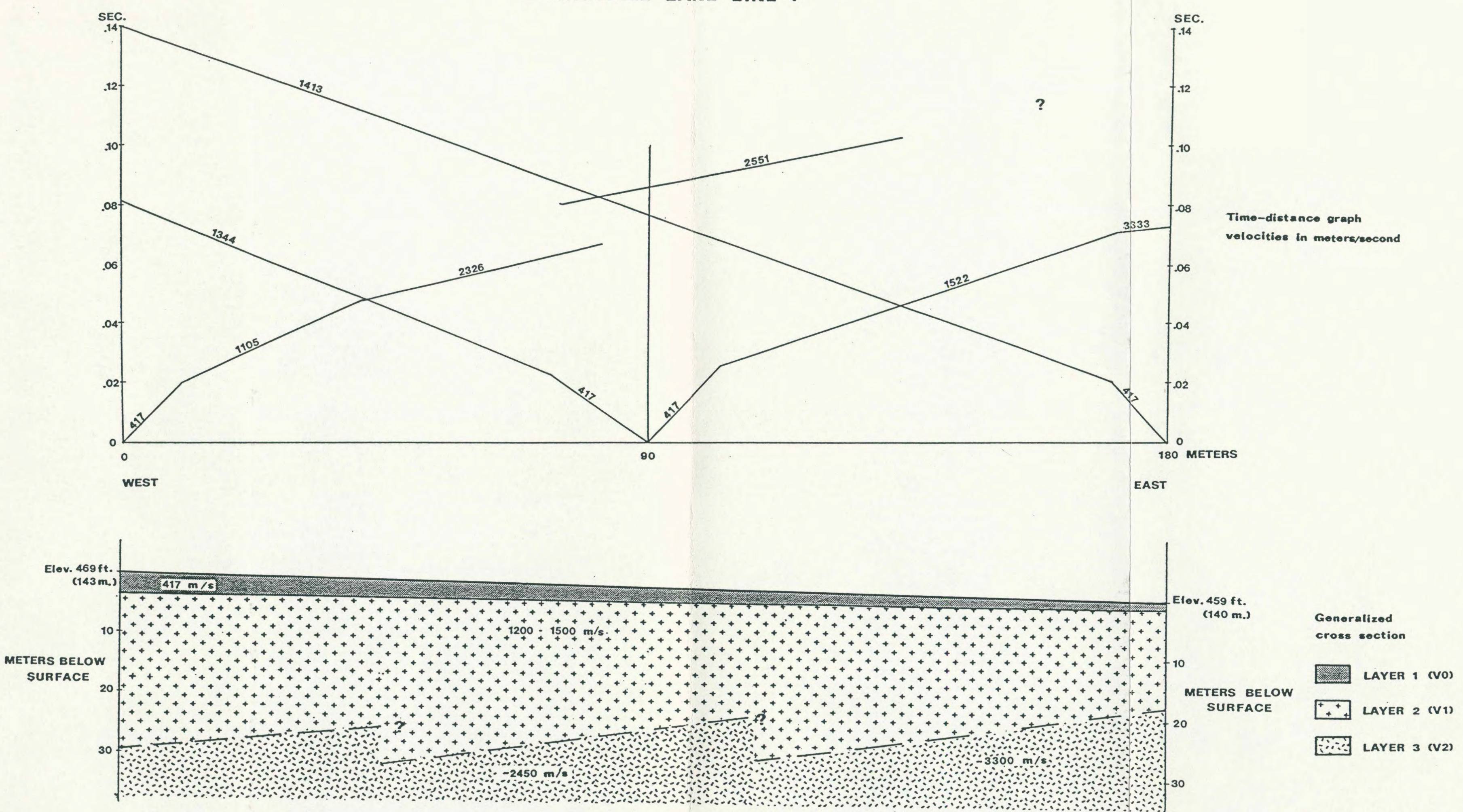
to represent a third layer. A third velocity layer is also indicated by the apparent velocity of $3333 \mathrm{~m} / \mathrm{s}$ on eastern end of the timedistance plot (See Figure 16).

The "true" velocities and depths to the refracting layers are shown on the generalized cross section. The second layer has a true velocity ranging from 1200 to $1500 \mathrm{~m} / \mathrm{s}$ and occurs at a depth of 2 to 3 meters below the surface. This layer is nearly horizontal, having a dip between 0 and 3 degrees to the east. The third layer is estimated to have a velocity between 2400 and $3400 \mathrm{~m} / \mathrm{s}$ and occur at a depth of 18 to 30 meters below the surface. The off set velocity segments representing the third layer on the time-distance plot may indicate that this layer is broken into blocks with varying amounts of dip. The absence of the third layer on the west facing profiles is interpreted to indicate that the third layer dips westward.

\section{Springville Lane Line 2}

Springville Lane line two (See Figure 4), 180 meters long, was the "best behaved" of all the lines run in this study. The records were of good quality, the first breaks were generally easy to pick, and the time-distance curve had a relatively straight forward interpretation. Springville Lane has very little traffic and the line was run on a clear, calm day which resulted in collection of data with very little background noise. Furthermore, the seismic energy was transmitted with very little attenuation. The time-distance curve (Figure 17) can be interpreted as a nearly horizontal three-layer model.

The surface velocity was recorded to be between 400 and $700 \mathrm{~m} / \mathrm{s}$ which is in agreement with the surface layer velocity recorded for 
SPRINGVILLE LANE LINE 2
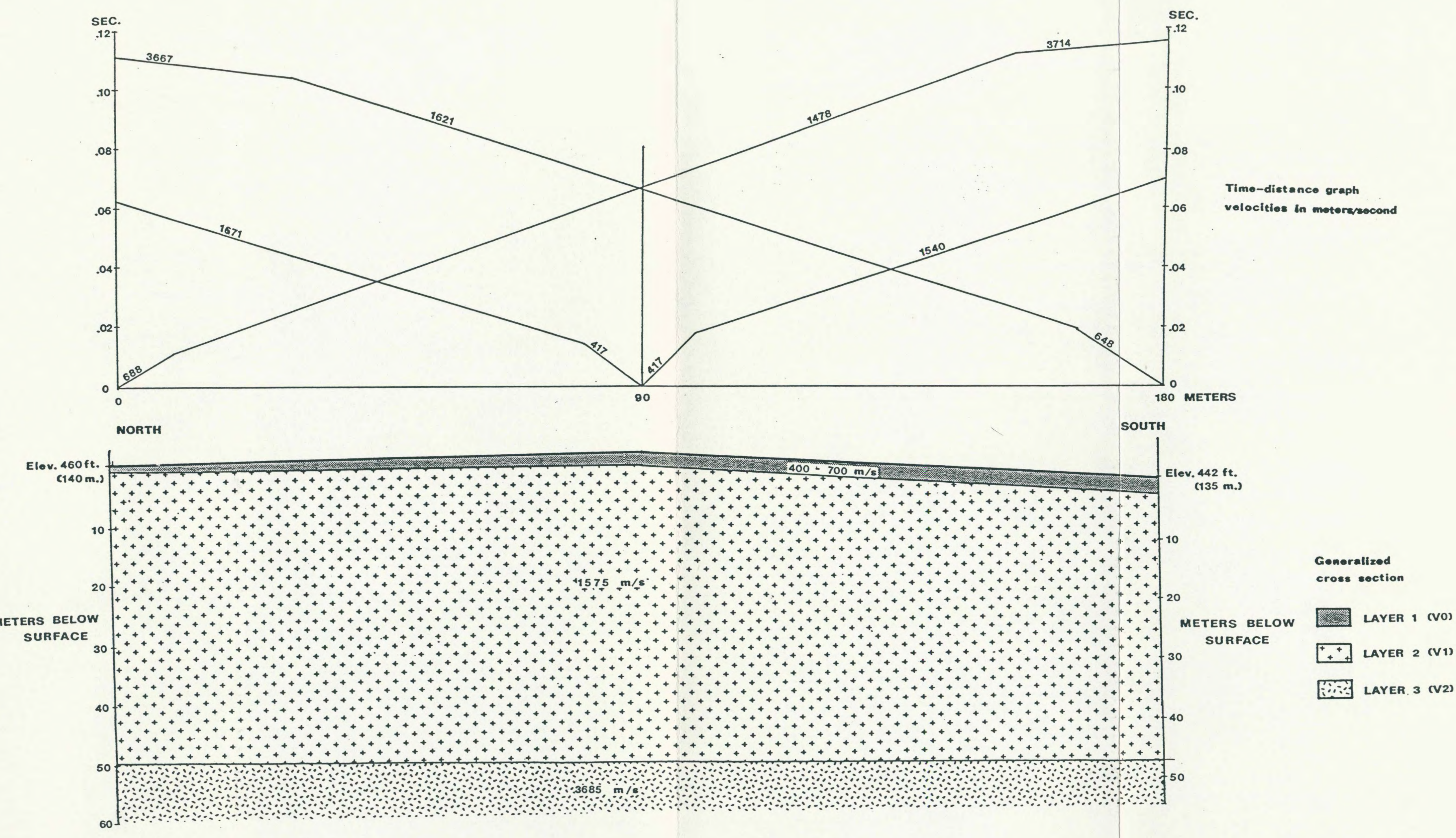

Figure 17. Springville Lane refraction line 2,

time-distance plot and generalized cross section. 
Springville Lane line one. The direct wave may have encountered higher velocity material near the 0 and 180 meter (from the north end of the line) shot points resulting in faster surface velocities. Apparent velocities for the second layer ranged from 1478 to $1540 \mathrm{~m} / \mathrm{s}$ for profiles shot in the southern direction and 1621 to $1671 \mathrm{~m} / \mathrm{s}$ for profiles shot in the northern direction. Apparent velocities of 3667 and 3714 $\mathrm{m} / \mathrm{s}$ were recorded for the third layer. Nearly all of the first breaks plotted directly on straight lines indicating relatively smooth refracting horizons.

A schematic cross section for Springville Lane line two is presented in Figure 17. The surface layer was calculated to have a thickness ranging from 1 to 3 meters. The first refracting horizon dips southward less than 1 degree and has an actual velocity of approximately $1575 \mathrm{~m} / \mathrm{s}$. The third layer occurs at a depth of 48 to 50 meters and dips southward a fraction of a degree. This layer has a calculated true velocity of $3685 \mathrm{~m} / \mathrm{s}$.

\section{Germantown Road Line}

A 90 meter refraction line was run along the southern edge of NW Germantown Road about 15 meters east of the intersection with NW Kaiser Road (See Figure 5). This location was chosen for the purpose of attempting a correlation with the data collected along NW Kaiser Road south of the intersection. There was good transmission of the seismic energy and good records were obtained in the field. This line encountered a high velocity layer very near the surface. Interpretation of the time-distance plot (Figure 18) indicates the presence of three velocity layers with refracting surfaces roughly parallel to the sur- 


\section{GERMANTOWN ROAD LINE}

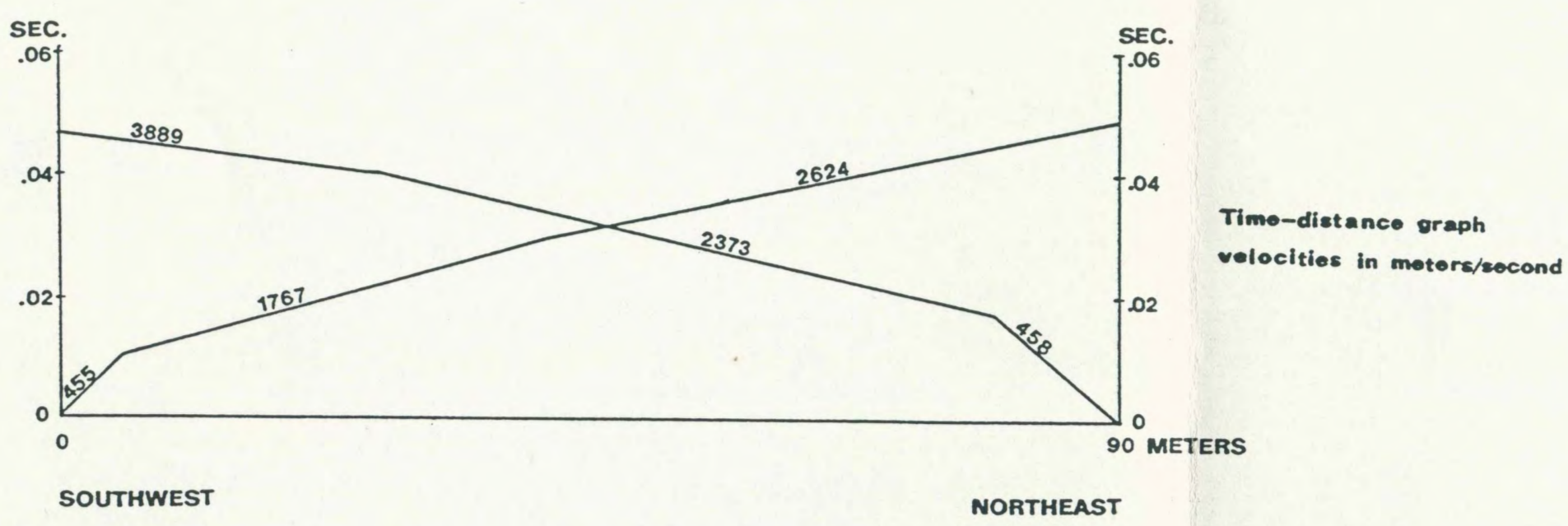

Elev. $270 \mathrm{ft}$

(82 m.)

10

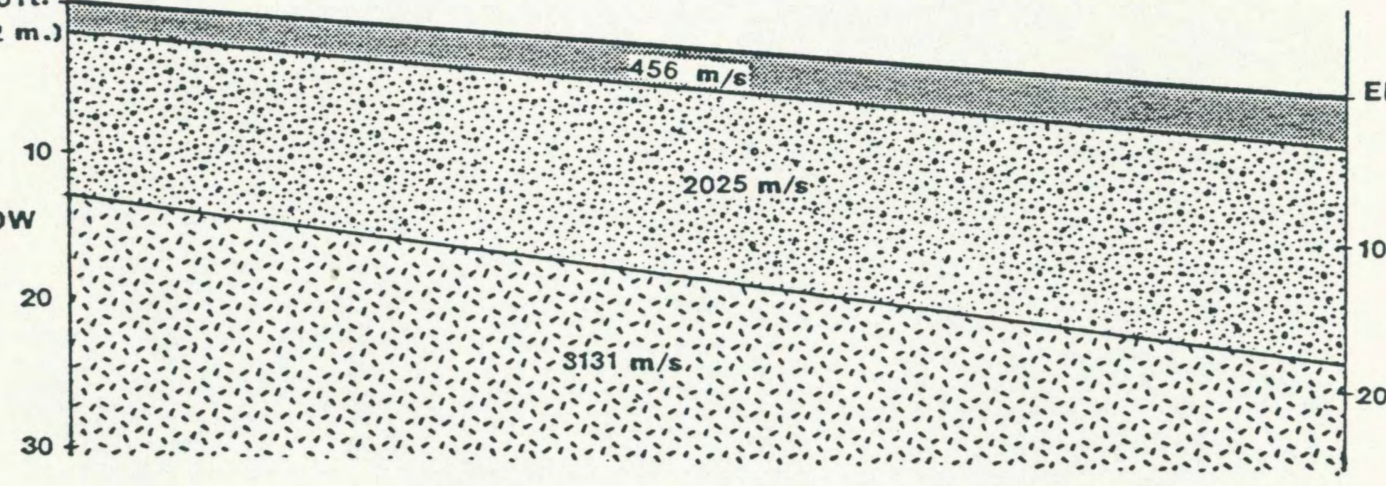

Elev. $252 \mathrm{ft}$

$(77 \mathrm{~m}:)$

Generalized

cross section

METERS BELOW

SURFACE

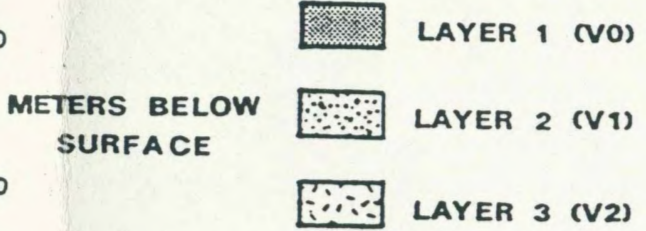

Figure 18. Germantown Road refraction line, timedistance plot and generalized cross section. 
face topography.

The surface layer along this line is relatively thin which caused some difficulty recording an acurate surface velocity. The first refracting horizon was recorded as the first break by the second geophone which was spaced 10 meters from the shot point. Therefore, the surface velocity was only recorded by the closest geophone to the shot point and was assigned a value of $456 \mathrm{~m} / \mathrm{s}$. This value was based on the first arrivals recorded at each end of the line and is in agreement with surface velocities recorded on other lines.

A true velocity of $2025 \mathrm{~m} / \mathrm{s}$ was calculated for the second layer. This layer is represented by apparent velocities of 1767 and $2373 \mathrm{~m} / \mathrm{s}$. A third layer is indicated on the time-distance curve by the apparent velocities segments of 2624 and $3888 \mathrm{~m} / \mathrm{s}$. This layer has a true velocity of $3131 \mathrm{~m} / \mathrm{s}$.

The true velocities and depth to velocity layers are shown on the schematic cross section in Figure 18. The second layer occurs at a depth of 2 meters below the southwest shot and 3.5 meters below the northeast shot. The upper surface of this layer dips northeastward approximately 5 degrees. The third layer dips about 7 degrees eastward and occurs at a depth of 13 to 17 meters below the surface.

\section{Kaiser Road Line}

Kaiser Road Line, 180 meters long, was run in a southern direction from the intersection of NW Germantown and NW Kaiser Road, nearly perpendicular to Germantown Road Line (See Figure 5). The purpose of this location was to record the seismic velocity of Columbia River basalt which crops out on the northern half of the line. Similar to 
Germantown Road Line, there was low attenuation of the seismic energy, the first breaks were clearly visible, and the records were good compared with most of the other lines. The time-distance plot (Figure 19) is interpreted to represent two velocity layers, the upper (weathered) velocity being recorded by only the first two phones at the southern end of the profile. The second layer, which has a relatively high velocity, occurs at the surface on the northern end of the line.

The surface velocity was recorded to be $556 \mathrm{~m} / \mathrm{s}$. This value is in aggreement with surface velocities measured on other lines, although it was recorded by only one shot point on this line.

Apparent velocities recorded for the second layer ranged from 2167 to $3366 \mathrm{~m} / \mathrm{s}$ with an average value of about $2600 \mathrm{~m} / \mathrm{s}$. The higher velocities were recorded on the northern end of the line. True velocities were calculated to be between 2600 and $3100 \mathrm{~m} / \mathrm{s}$. The field data plots as a series of segments having relatively the same slope on the time-distance curve, thus indicating that the upper surface of the second layer may be broken up into separate blocks. The amount of offset between blocks is a few meters or less and therefore not shown on the schematic cross section.

The generalized cross section for Kaiser Road line is presented in Figure 19. The dip of the interface between the two layers varies between 0 and 3 degrees to the south. The second layer occurs at a depth of 6 meters at the south end and at the surface on the north end of the line.

Rock Creek Line

Rock Creek line, 145 meters in length, was run along the northern 
KAISER ROAD LINE
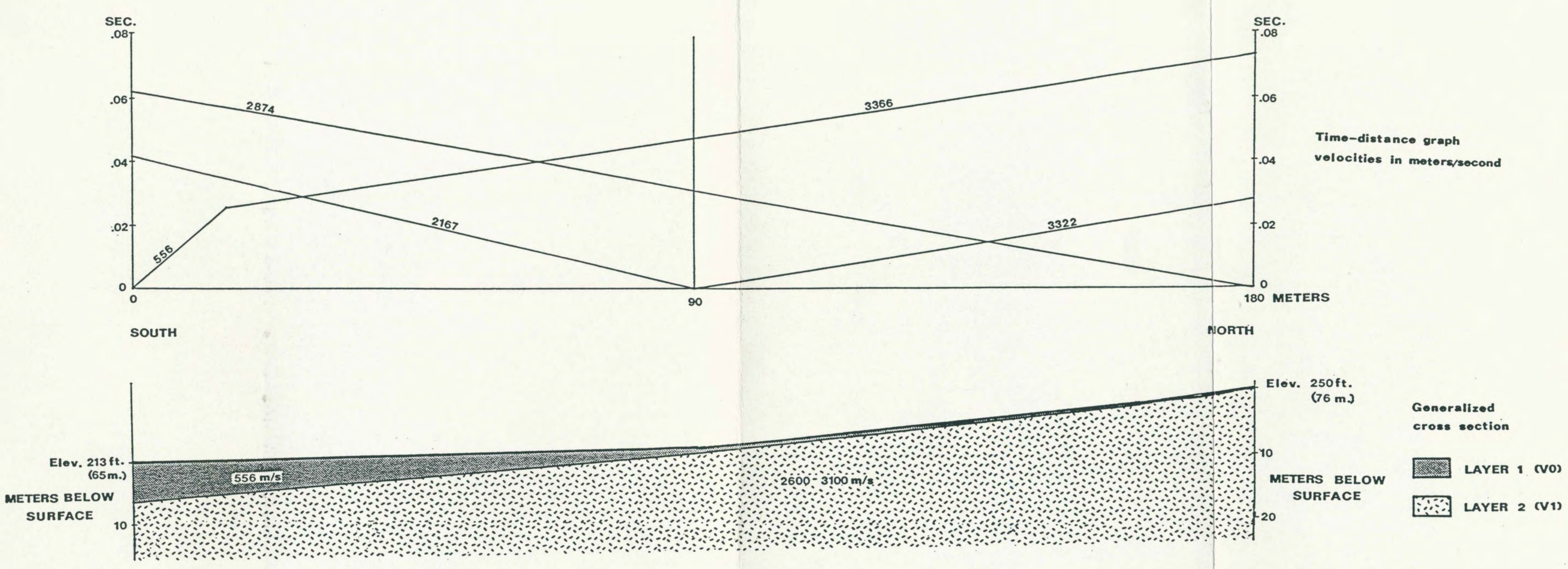
Figure 19. Kaiser Road refraction line, time-distance
plot and generalized cross section. 
edge of NW Germantown Road (See Figure 5). This location was chosen for the purpose of attempting to locate the subsurface contact between the Columbia River basalt and the alluvium occurring near Rock Creek. The velocity difference between stream alluvium $(400-2000 \mathrm{~m} / \mathrm{s})$ and underlying basalt $(2500-4500 \mathrm{~m} / \mathrm{s})$ indicate that this surface should be detectable by seismic refraction (Telford and others, 1976). Heavy traffic noise along NW Germantown Road and problems with the operation of the electric winch resulted in the collection of records that were of relatively poor quality. Furthermore, the total travel time for the westward profile had to be reduced 0.030 seconds to make the total travel times equal for each shot. In theory, the total travel times (from source to most distant geophone) must be equal for reversed profiles.

Three velocity segments can be interpreted from the time-distance plot (Figure 20). An accurate surface velocity was not obtained because of the large geophone spacing used on this line (10 - 15 meters). The surface layer is estimated to have a velocity of $556 \mathrm{~m} / \mathrm{s}$. This value is based on the first breaks recorded by the geophones nearest to the shot points and surface velocities recorded on other lines.

Apparent velocities of 1167 and $1484 \mathrm{~m} / \mathrm{s}$ were recorded for second velocity layer. The calculated true velocity for this layer is 1304 $\mathrm{m} / \mathrm{s}$. The third layer has a velocity of $4205 \mathrm{~m} / \mathrm{s}$. This value was calculated from apparent velocities of 4394 and $4105 \mathrm{~m} / \mathrm{s}$.

The second layer is nearly parallel to the surface topography and occurs at a depth of 2.5 to 4.5 meters below the surface (See Figure 20). The third layer occurs at a depth of 13 meters below the west 
ROCK CREEK LINE

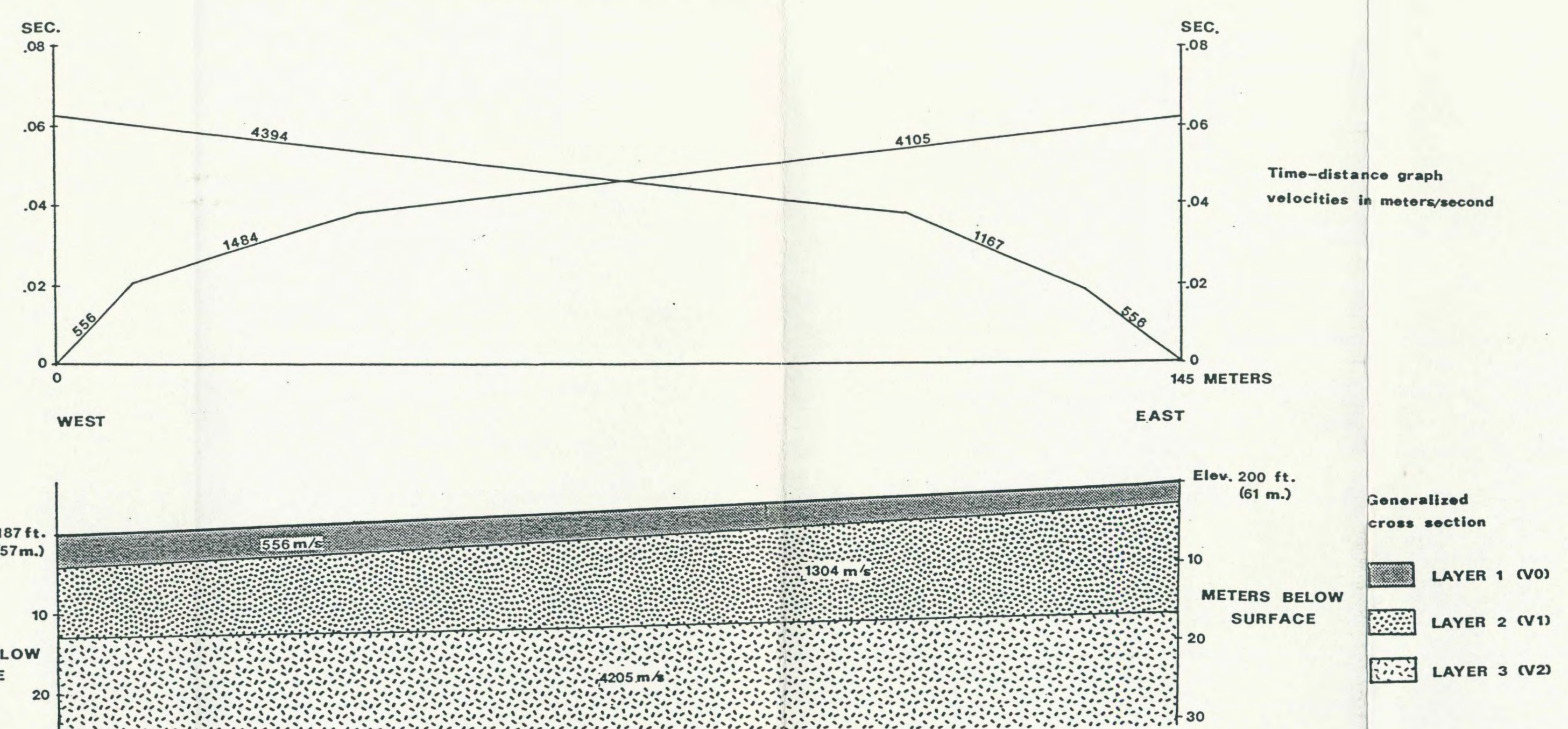


shot point and 17 meters below the east shot point. This implies that the third layer is horizontal.

\section{Cornelius Pass Line}

Cornelius Pass Line (See Figure 6) was the first line run in this study. The purpose of this line was to record the depth to Columbia River basalt which has been mapped at this location (Trimble, 1963; Sch1icker and Deacon, 1967). This line was started near the intersection with NW Kaiser Road with the intention of continuing it southward into the valley along Cornelius Pass Road. Cornelius Pass Road is one of the main thoroughfares in the area which caused a problem with background noise. First breaks could not be distinguished on the record past 90 meters. Although field work at this location was discontinued after the first day, two 90 meter segments were completed on either side of NW Kaiser Road.

The time-distance plot (Figure 21) for the segment north of NW Kaiser Road is interpreted to represent three velocity layers that nearly parallel the surface topography. The surface layer has an average velocity of $432 \mathrm{~m} / \mathrm{s}$. This layer is estimated to vary in thickness from 2 to 4.5 meters. The surface layer is apparently thicker at the northern end of the line.

The second layer is represented by apparent velocities of 1076 and $1562 \mathrm{~m} / \mathrm{s}$ on the time-distance curve (See Figure 21). This layer has a true velocity of $1271 \mathrm{~m} / \mathrm{s}$ and dips about 4 degrees to the south. The third layer has a velocity of $2911 \mathrm{~m} / \mathrm{s}$. The apparent velocities recorded for this layer range from 2121 to $4669 \mathrm{~m} / \mathrm{s}$. The second refracting surface occurs at a depth of 15 meters below the south shot 
CORNELIUS PASS LINE

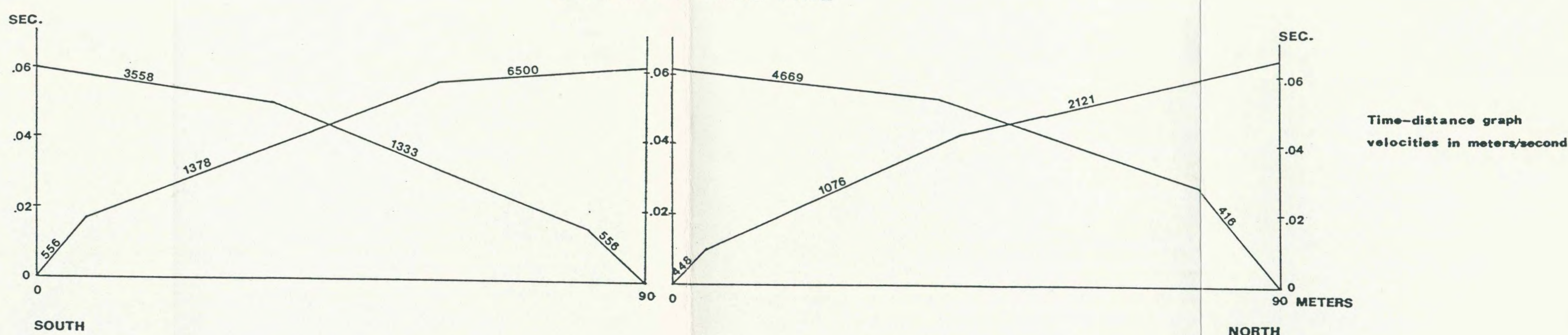

SOUTH

NORTH

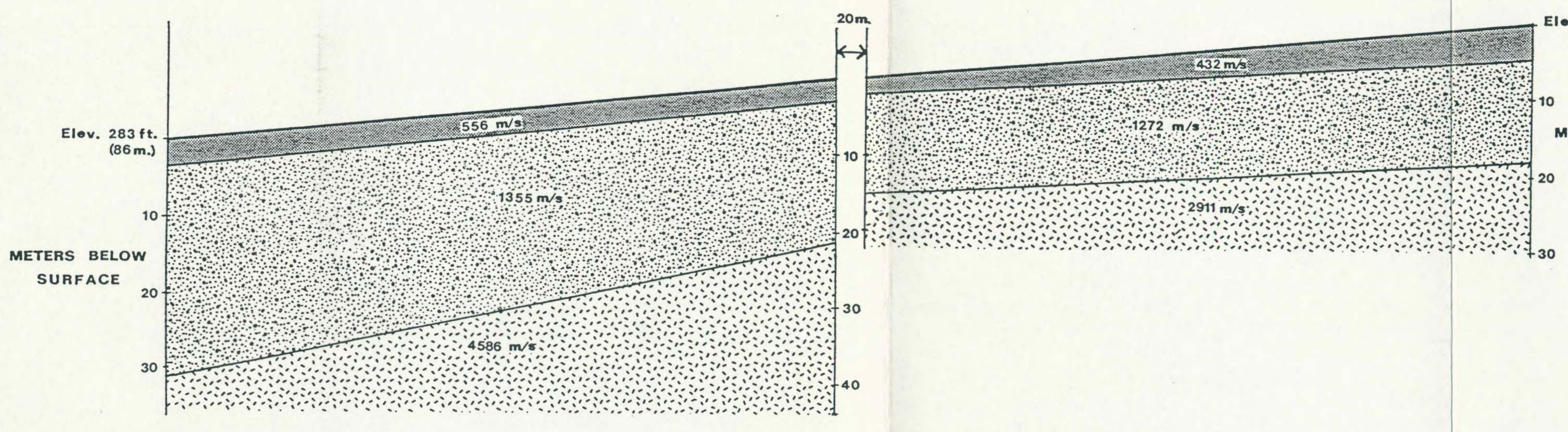
(101 m.) Generallized
cross soction
LAYER 1 (VO)
METERS BELOW SURFACE
LAYER 2 (VI)
LAY LAB 3 (V2)

Figure 21. Cornelius Pass refraction line, time-distance plot and generalized cross section. 
and 18 meters below the north shot. This surface has an apparent dip of 3 degrees to the south.

The data recorded for the 90 meter segment run south of NW Kaiser Road has a similar appearance to the previous segment run on Cornelius Pass Road although higher velocities are indicated on the time-distance plot (See Figure 21). This segment can be modeled as three velocity layers which dip to the south.

The surface layer has a velocity of $556 \mathrm{~m} / \mathrm{s}$. This layer has a thickness of 3 meters below the north shot and 3.5 meters below the south shot point. These values are in agreement with those calculated for the first segment of this line.

A true velocity of $1355 \mathrm{~m} / \mathrm{s}$ was calculated for the second layer, which is similar to the corresponding layer in the first segment. Apparent velocities of 1333 and $1377 \mathrm{~m} / \mathrm{s}$ were recorded for this layer. The second layer has an apparent dip of about 5 degrees to the south. The upper surface of this layer roughly parallels the surface topography .

The velocity and depth to the third layer deviates from the values calculated for the first segment. Apparent velocities recorded for this layer ranged from 3558 to $6500 \mathrm{~m} / \mathrm{s}$. A true velocity of 4586 $\mathrm{m} / \mathrm{s}$ was calculated for the third layer. The third layer occurs at a depth of 22 meters below the north shot and 30 meters below the south shot point (See Figure 21). The top of the third layer has an apparent dip of 10 degrees to the south. 


\section{SUMMARY AND CONCLUSIONS}

The generalized cross sections that have been presented thus far illustrate velocity layers in the subsurface. The velocities and depths to the layers are calculated values that represent possible models of the data that was collected on each line. The following cross sections are geologic interpretations of the velocity - layer models. The interpretations are based primarily on the refraction data along with previous mapping in the area and observations in the field. The cross sections in this chapter represent possible geologic models of the calculated geophysical models.

Figure 22 contains cross sections of the four refraction lines in the northwest half of the study area (See Figures 5 and 6) along with Laidlaw Road refraction line (See Figure 4). These cross sections are grouped together because of their similar appearance and interpretation.

All five cross sections contain three layers with the exception of Kaiser Road line, which has only two. The surface layer in each cross section ranges in velocity from 432 to $577 \mathrm{~m} / \mathrm{s}$. This relatively low velocity is indicative of very poorly consolidated material such as soil or alluvium (Dobrin, 1960). This layer ranges in thickness from 0 to 7 meters and occurs as a fairly uniform surface layer which appears to mantle the topography. This layer is interpreted as alluvium on Rock Creek refraction line and loessal deposits of Willamette and Upland silt on the other lines. 

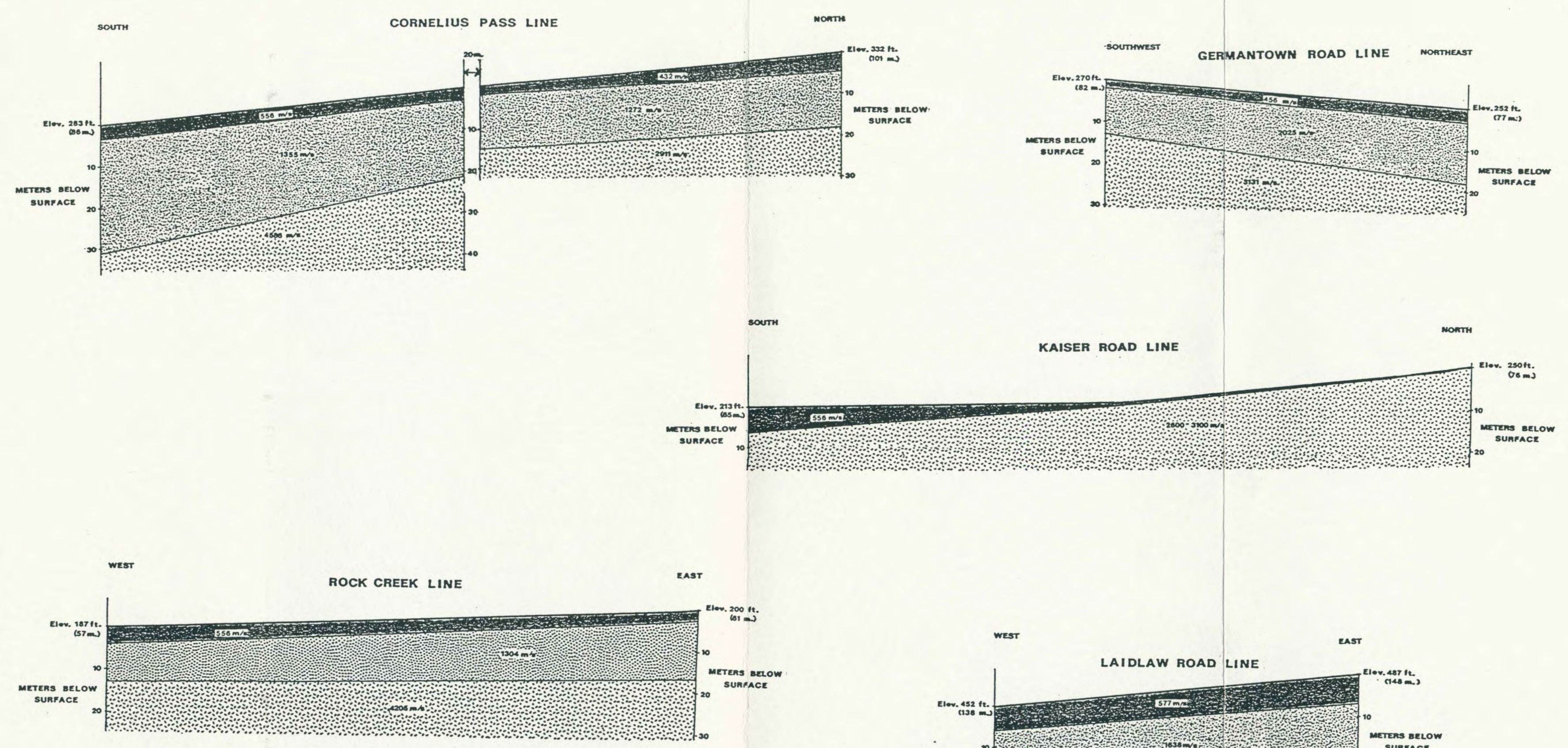

Loessal Deposits - Alluvium

Weathered Basalt

Columbia River Basalt

Figure 22. Comparison and interpretation of Cornelius

Pass, Rock Creek, Germantown Road, Kaiser Road, and Laidlaw

Road refraction lines.

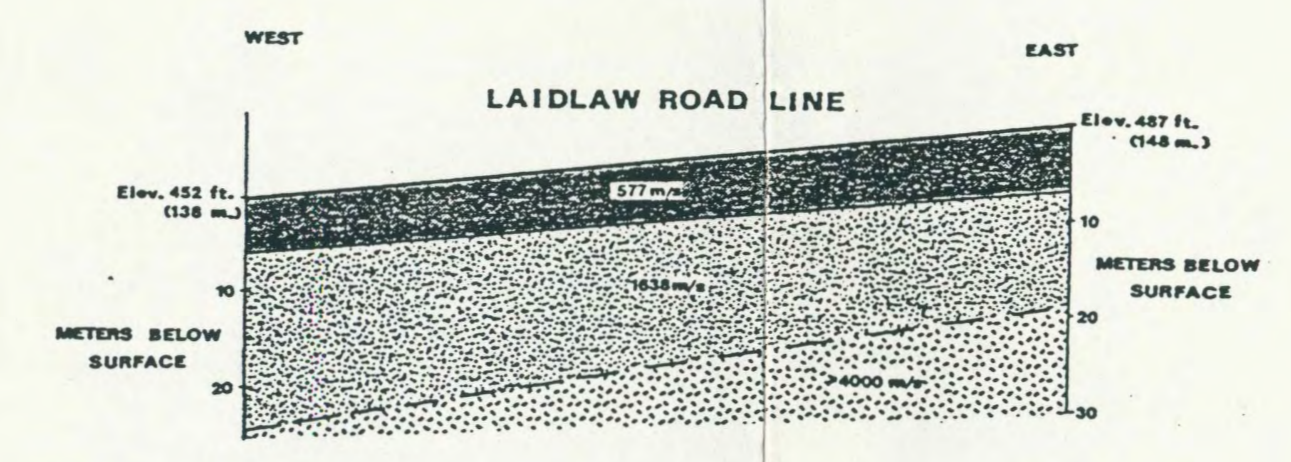


The second layer, which is absent from Kaiser Road line, can be interpreted as highly weathered basalt or sedimentary rock. This layer ranges in velocity from 1272 to $2025 \mathrm{~m} / \mathrm{s}$ and averages about 15 meters thick. The velocities of clay $(915-1830 \mathrm{~m} / \mathrm{s})$, sandstone $(1830-2440$ $\mathrm{m} / \mathrm{s})$, and fractured basalt $(2745-4270 \mathrm{~m} / \mathrm{s})$, (Redpath, 1973) are within the range of the velocity for the second layer. Trimble (1963) notes that the basalt in the Tualatin Mountains readily alters to clay minerals and the alteration (weathering) may be as deep as 52 meters (Allen, 1948). The velocity of fractured basalt would be lowered depending on the degree of weathering. The velocity of the second layer is also within the range that would be expected for the sand, silt, and clay of the Troutdale Formation.

The third layer $(2911-4586 \mathrm{~m} / \mathrm{s})$ is interpreted as Columbia River basalt. Fresh vesicular basalt crops out inthe ditch along along NW Kaiser Road at the north end of the line. This unit was interpreted to be high-Mg Grande Ronde Basalt (Beeson, pers. com., 1987). All five lines were run at locations where Trimble (1963) has mapped Columbia River basalt (See Figures $4-6$ ), although the only outcrops of fresh basalt were found along NW Kaiser Road. The basalt occurs at depths ranging from 0 to 31 meters, averaging around 17 meters below the surface. It should be noted that the upper surface of the basalt roughly parallels the surface topography on each cross section. This may indicate that the basalt controls the topography and the second velocity layer is weathered basalt, which would be expected to overlie fresh rock. It is uncertain as to why the weathered layer is absent from the Kaiser Road line. 

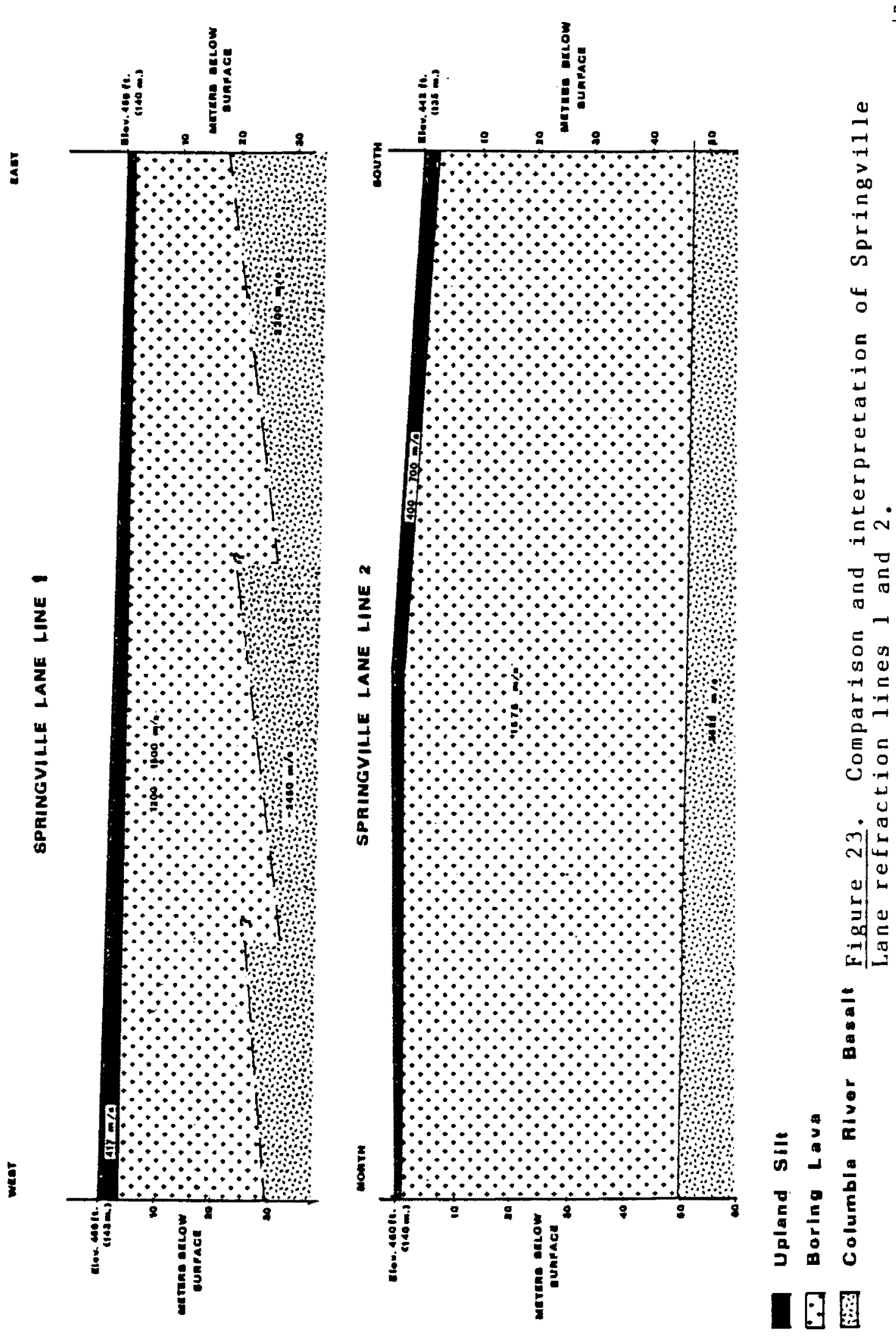
Figure 23 illustrates the geologic interpretation of Springville Lane lines 1 and 2 (See Figure 4). These lines are located along the margin of an area that has been mapped as Boring Lava by Trimble (1963) and Schlicker and Deacon (1967). The area immediately to the west topographically resembles a Boring Lava cone (See Figure 2), although no outcrops of Boring Lava were found in the field. Consistent data was collected from each line and both were modeled as three velocity layers.

The surface layer is interpreted as Upland silt. The velocity $(400-700 \mathrm{~m} / \mathrm{s})$ is similar to the surface velocities recorded on other Iines and Upland silt was expected to occur here. The silt mantles the topography and ranges in thickness from 2 to 4 meters.

The velocity of the second layer $(1200-1575 \mathrm{~m} / \mathrm{s})$ is indicative of weathered basalt or a sedimentary unit. This layer is shown to range in thickness from 16 to 48 meters and is interpreted as Boring Lava. Trimble (1963) notes that Boring Lava may be weathered 25 feet $(7.6 \mathrm{~m})$ or more. The relatively low velocity of the basalt may be due to an average velocity of highly weathered and fractured basalt. The spheroidal weathering of Boring Lava (Trimble, 1963) may result in the seismic signal traveling with several high- and low-velocity segments which would result in an average velocity lower than what would be expected for fresh basalt. A low velocity (weathered) zone on top of the third layer may have lowered the average velocity further, thus causing the second layer to appear thicker than it actually is.

The third velocity layer $(2450-3685 \mathrm{~m} / \mathrm{s})$ is shown as Columbia River basalt on the cross sections. This velocity is within the range 
of what was recorded for Columbia River basalt on other lines. This layer may actually be Boring Lava. The seismic velocity of unweathered Boring Lava could be the same as the seismic velocity of Columbia River basa1t.

The difference between the upper surface of the third layer in each cross section in Figure 24 can be explained by the two timedistance plots. Springville Lane line 2 has three distinct velocity segments in both directions of the reversed profile (See Figure 17). This can be modeled as three nearly-horizontal velocity layers. The reversed profiles on Springville Lane line 1 (See Figure 16) do not appear to match and have been modeled as a series of broken blocks. This is interpreted to indicate that Springville Lane line 1 was run perpendicular to the local subsurface structure while Springville Lane line 2 was run parallel to the local structure and therefore did not detect any structural discontinuities.

Figure 24 illustrates the geologic interpretation of the three remaining refraction lines. Bronson Creek refraction line was run across an area that has been mapped as Columbia River basalt (Trimble, 1963) and Troutdale Formation (Hart and Newcomb, 1965) (See Figure 4). The surface layer velocity $(500-900 \mathrm{~m} / \mathrm{s}$ ) (See Figure 15) is indicative of poorly consolidated sediment. The surface layer is interpreted as Troutdale Formation mantled by Upland silt. The two formations may not be distinguishable through seismic refraction and are therefore grouped together here. The lower surface velocities $(500 \mathrm{~m} / \mathrm{s})$ recorded in the central part of the line could indicate that the loessal deposits are thicker on the crest of the ridge. The higher surface 


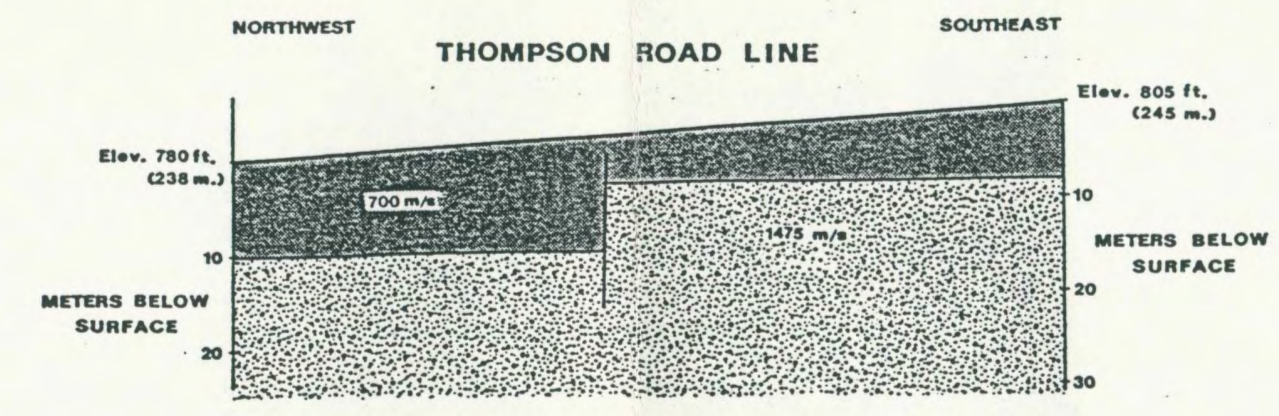

MORTHWEST

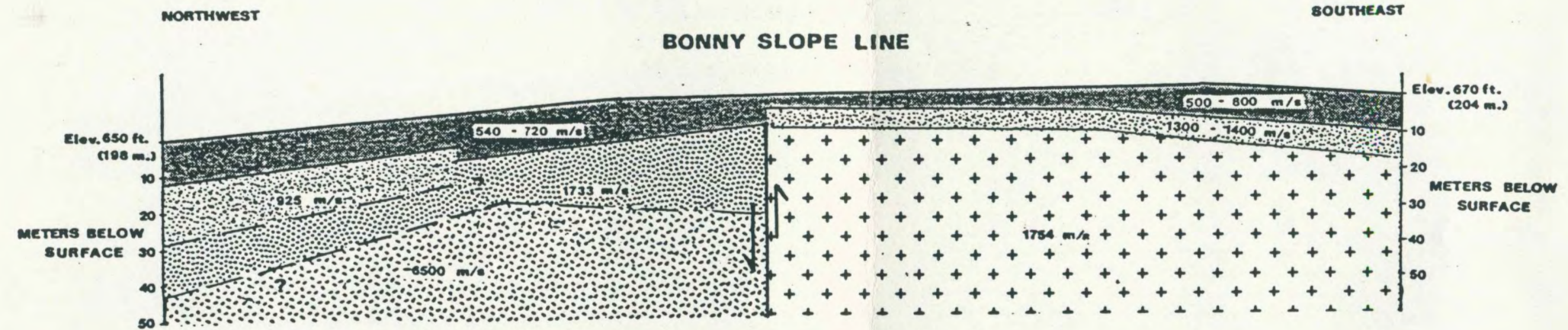

BRONSON CREEK LINE

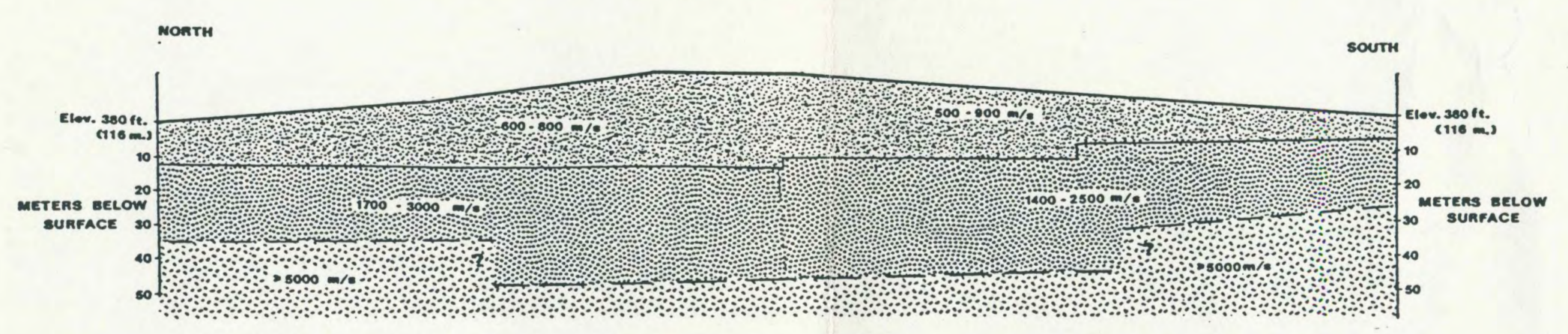

Figure 24. Comparison and interpretation of Thompson Road, Bonny Slope, and Bronson Creek refraction lines.
Upland Silt

Weathered Basalt

\section{Upland Silt}

Troutdale Formation

Weathered Basalt

济注等 Columbia River Basalt

+++ Scappoose Formation

Upland Silt-Troutdale Formation

1.7. weathered Basalt

Columbia River Basalt 
velocities ( $900 \mathrm{~m} / \mathrm{s}$ ) recorded from the end shot points may be the result of more Troutdale "influence".

The second layer shown in the Bronson Creek cross section (1400 $3000 \mathrm{~m} / \mathrm{s}$ ) could be interpreted as weathered basalt or compacted sediment. Because of the line location and the depth of the unit, fractured or weathered basalt is more likely than sediment, although the Troutdale may grade into Columbia River basalt through a weathered basalt zone.

A faulted or very steeply dipping third layer is indicated by the very high apparent velocities on the time-distance plot (See Figure 15). This layer, which is interpreted as Columbia River basalt, may be broken into blocks.

Thompson Road and Bonny Slope refraction lines were run for the purpose of examining the sedimentary unit that Trimble (1963) has mapped as Sandy River mudstone, Schlicker and Deacon (1967) have mapped as Troutdale Formation, and Thoms (pers. com., 1987) has interpreted as Scappoose Formation. The town of Bonny Slope (See Figure 3) is located on an exposed "window" of sediment that is presumably stratigraphically below the Columbia River basalt. The data collected on the Bonny Slope line indicate that the sedimentary unit is not underlain by high velocity material (Columbia River basalt). Thus it is concluded that this sedimentary unit is part of the Scappoose Formation.

The surface velocity $(500-800 \mathrm{~m} / \mathrm{s})$ layer on Thompson Road and Bonny Slope lines is interpreted as Upland silt. This layer varies in thickness from 3 to 12 meters and is found throughout both lines. The second layer on Thompson Road line was modeled as being faulted with 
about 8 meters of offset. Based on its velocity, location, and the presence of basalt cobbles in the soil along Thompson Road, this layer is interpreted as weathered basalt. A third layer was not detected on Thompson Road line.

The data collected on the Bonny Slope refraction line indicate that this was the only line in the study that crossed a large, shallow (0 - $50 \mathrm{~m}$ ) velocity discontinuity. The time-distance plot (See Figure 13) indicates several discontinuous velocity layers. The velocity layers were interpreted as separate geologic units (See Figure 24), although the different velocities may be related to degree of compaction or the presence of water, not necessarily changes in lithology .

The main point to note on the Bonny Slope refraction line is that the Columbia River basalt is absent from the southeast half of the line. A high velocity $(>3000 \mathrm{~m} / \mathrm{s})$ layer was encountered on the northwest half of the line, although the data indicate that this unit is discontinuous or possibly steeply dipping (apparent velocities of 7500 and $7667 \mathrm{~m} / \mathrm{s}$ ). In the central part of the line, attenuatuation of the seismic energy indicated disrupted, rather than smooth refracting horizons. Based on these observations, the Bonny Slope line was modeled to include a fault. This may be an erosional contact between the Columbia River basalt and the Scappoose Formation rather than a fault plane as is shown in the cross section (Figure 24). Dispersion of the seismic signal would also be expected along a steeply dipping erosional surface. The geologic models produced could not prove or disprove the presence of a major fault in the study area, although the data col- 
lected on the Bonny Slope line supports the hypothesis that the Scappoose Formation is exposed at the town of Bonny Slope.

The following general conclusions can be made from this study: 1) Upland silt mantles most of the study area at fairly uniform thicknesses ranging from 2 to 10 meters. 2) Columbia River basalt roughly parallels the surface topography at depths of 0 to 30 meters averaging around 15 meters below the surface. 3) The basalt is usually overlain by a 5 to 15 meter thick layer interpreted to be a weathered zone. This layer is usually of uniform thickness and parallels the basalt. 4) Offset refacting horizons indicate that the Columbia River basalt is broken up into blocks in several places. 


\section{REFERENCES CITED}

Allen, J.E., 1975, Volcanoes in the Portland area, Oregon: The Ore Bin, v. 37, no. 9, p. $145-157$.

Allen, V.T., 1948, Formation of bauxite from basaltic rocks of Oregon: Economic Geology, v. 43, no. 8, p. $619-688$.

Allison, I.S., 1933, New version of the Spokane flood: Geological Society of America Bulletin, v. 44, no. 4, p. $675-722$.

- 1935, Glacial erratics in the Willamette Valley: Geological Society of America Bulletin, v. 46, no, 4, p. $615-632$.

1936, Pleistocene alluvial stages northeastern Oregon: Science, v. 83, no. 2158, p. $441-443$.

Anderson, J.L., 1978, The stratigraphy and structure of the Columbia River basalt in the Clackamas River drainage: unpublished thesis, M.S., Portland State University, Portland, Oregon.

Balsillie, J.H., and Benson, G.T., 1971, Evidence for the Portland Hills fault: The Ore Bin, v. 33, no. 6, p. $109-118$.

Beeson, M.H., Fecht, K.R., Reidel, S.P., Tolan, T.L., 1985, Regional correlations within the Frenchman Springs Member of the Columbia River Basalt Group: New insights into the middle Miocene tectonics of northwestern Oregon: Oregon Department of Geology and Mineral Industries, v. 47, no. 8, p. $87-96$.

Beeson, M.H., Johnson, A.G., Moran, M.R., 1976, Portland environmental geology - fault identification; Final technical report to United States Geological Survey: Earth Sciences Dept., Portland State University, Portland, Oregon.

Benson, G.T., and Donovan, J.C., 1974, Preliminary tectonic map of the greater Portland area: in Hammond, P.E., and others, 1974, A preliminary geological investigation of the ground effects of earthquakes in the Portland metropolitan area, Oregon: unpublished report to the United States Geological Survey (PEG I report), Portland State University, Portland, Oregon.

Bretz, J. Harlan, 1925, The Spokane flood beyond the channeled scablands: Journal of Geology, v. 33, no. 2, p. $97-115$ and 236 259. 
, 1928, Alternate hypothesis for channeled scabland: Journal of Geology, v. 36, no. 3, p. $193-223$ and $312-341$.

Couch, R., and Lowell, R.P., 1971, Earthquakes and seismic energy release in Oregon: The Ore Bin, v. 33, no. 4, p. $61-84$.

Crosson, R.S., 1972, Small earthquakes, structure and tectonics of the Puget Sound region: Seismological Society of America Bulletin, v. 62 , no. 5 , p. $1133-1171$.

Dehlinger, P., 1969, Tectonic processes in the Juan de Fuca and Gorda ridges, and their implications for global tectonics: EOS, v. 50, p. 186 (abstract).

Dehlinger, P., and Couch, R.W., 1969, Synthesis of geophysical results in the Juan de Fuca and Gorda Ridge areas (Northeast Pacific Ocean): EOS, v. 50, p. 186 (abstract).

Dobrin, M.B., 1960, Introduction to geophysical prospecting: New York, McGraw Hill Book Company; 1976, 3rd edition.

Dix, C.H., 1939, Refraction and reflection of seismic waves, I. Fundamentals: Geophysics, v. 4, no. 2, p. 81 - 101 . , 1939, Refraction and reflection of seismic waves II. Discussion of the physics of refraction prospecting: Geophysics, v. 4, no. 4, p. $238-241$.

, 1941, Notes on refraction prospecting: Geophysics, v. 6, no. 4, p. $378-396$.

, 1952, Seismic prospecting for oil: New York, Harper and Row.

Ewing, M., Wollard, G.P., and Vive, A., 1939, Geophysical investigations in the emerged and submerged Atlantic coastal plain, Part III: Geological Society of America Bulletin, v. 50, p. $257-296$.

Glen, Jerry Lee, 1965, Late Quaternary sedimentation and geologic history of the north Willamette Valley, Oregon: Unpublished doctoral dissertation, Oregon State University, Corvallis, Oregon, $231 \mathrm{p}$.

Haas, Nina, 1983, A geophysical study of the North Scappoose Creek Alder Creek - Clatskanie River linement, along the trend of the Portland Hills fault, Columbia County, Oregon: unpublished thesis, M.S., Portland State University, Portland, Oregon. 
Hammond, P.E., Benson, G.T., Cash, D.J., Palmer, L.A., Donovan, J., and Gannon, B., 1974, A preliminary geologic investigation of the ground effects of earthquakes in the Portland Metropolitan area, Oregon: unpublished report to the United States Geological Survey .

Hart, D.H., and Newcomb, R.C., 1965, Geology and ground water of the Tualatin Valley, Oregon: U.S. Geol. Survey Water-Supp1y Paper 1697.

Heiland, C.A., 1968, Geophysical exploration: New York, Hafner Publishing Company.

Johnson, A.G., 1976, Gravity profiles across the northeast side of the Tualatin Mountains, Portland, Oregon: Transactions, American Geophysical Union, v. 57, no. 2, p. 89 (abstract).

Johnson, A.G, 1987, Assesment of seismic hazard for a site northeast of the Hillsboro airport: Report to H.G. Schlicker and associates, Geology Dept., Portland State University, Portland, Oregon.

Johnson, A.G., Jones, T., and Perttu, J.D., 1977, Interpretaion of gravity in the Portland area: Proc. of Oregon Academy of Science, p. 60 (abstract).

Jones, T.D., 1977, Analysis of a gravity traverse south of Portland, Oregon: Unpublished thesis, B.S., Portland State University, Portland Oregon.

Ku1m, L.D., and Fowler, G.A., 1974, Oregon continental margin structure and stratigraphy: a test of the imbicate thrust model, in Burk, C.A., and Drake, C.L., eds., The geology of continental margins: New York, Springer - Verlag, p. $4-12$.

Laster, S.J., Milo, M.B., Schell, R., 1967, Analog studies of the simple refraction arrivals: in Musgrave, A.W., ed., 1967, Seismic refraction prospecting: Tulsa, SEG.

Lentz, R.T., 1977, The petrology and stratigraphy of the Portland Hills Silt: Unpublished thesis, M.S., Portland State University, Portland Oregon.

Lowry, W.D., and Baldwin, E.M., 1952, Late Cenozoic geology of the lower Columbia River Valley, Oregon and Washington: Geologica1 Society of America Bulletin, v. 63, no. 1, p. 1 - 24.

Mota, Lindonor, 1954, Determination of dips and depths of geological layers by the seismic refraction method: Geophysics, v. 19, no. 2 , p. $242-254$.

Musgrave, A.W., 1967, Seismic refraction prospecting: Tulsa, Society of Exploration Geophysicists. 
Nettleton, L.L., 1940, Geophysical prospecting for oil: New York, Mc Graw-Hill Book company.

Newton, V.C., Jr., 1969, Subsurface geology of the Lower Columbia and Willamette Basins, Oregon: Oregon Department of Geology and Mineral Industries, Oil and Gas Investigation, No. 2.

Newton, V.C., and Van Atta, R. 0., 1976, Prosects for natural gas production and underground storage of pipe-line gas in the Upper Nehalem River basin, Columbia - Clatsop Counties, Oregon: Oregon Department of Geology and Mineral Industries Oil and Gas Investigations No. $5,56 \mathrm{p}$.

Northwood, E.J., 1967, Notes on errors in refraction interpretation: in Musgrave, A.W., ed., 1967, Seismic refraction prospecting: Tulsa, SEG.

Perttu, J.D., 1980, An analysis of gravity surveys in the Portland Basin, Oregon: unpublished thesis, M.S., Portland State University, Portland, Oregon.

Redpath, B.B., 1973, Seismic refraction exploration for engineering site investigations: U.S. Army Engineer Waterways Experiment Station, Livermore, California, Technical report E-73-4.

Reynolds, C.B., 1986, Analysis of shallow seismic refracrion data by microcomputer, in Hanley, J.T., and Merriam, D.F., eds., 1986, Microcomputer applications in geology: Pergamon Press.

Rockwell, D.W., 1967, General wavefront method: in Musgrave, A.W., ed., 1967, Seismic refraction prospecting: Tulsa, SEG.

Schlicker, H.G., and Deacon R.J., 1967, Engineering geology of the Tualatin Valley region: State of Oregon Dept. of Geology and Mineral Industries Bull. 60, $103 \mathrm{p}$.

Schlicker, H.G., Deacon, R.J., and Twelker, N.H., 1964, Earthquake geology of the Portland area, Oregon: The Ore Bin, v. 26, no. 12, p. $209-230$.

Schmela, R.J., 1971, Geophysical and geological analysis of a fault like lineation in the Lower Clackamas River area, Clackamas County, Oregon: unpublished thesis, M.S., Portland State University, Portland, Oregon.

Snavely, P.D., Jr., and Wagner, H.C., 1963, Tertiary geologic history of western Oregon and Washington: Washington Division of Mines and Geology, R.I. 22.

, 1964, Geologic sketch of northwest Oregon: United States Geological Survey Bulletin, no. 1181-M. 
Snavely, P.D., Jr., Wagner, H.C., and Lander, D.L., 1980, Interpretation of the Cenozoic geologic history, central Oregon continental margin: cross section summary: Geological Society of America Bulletin, Part I, v. 91, p. $143-146$.

Telford, W.M., Geldart, L.P., Sheriff, R.S., and Keys, D.A., 1976, Applied Geophysics: Cambridge, Cambridge University Press.

Theisen, A.A., 1958, Distribution and character of loess-like soil in northwestern Oregon: unpublished thesis, M.S., Oregon State University, Corvallis, Oregon.

Tolan, T.L., and Beeson, M.H., 1984, Intracanyon flows of the Columbia River Basalt Group in the lower Columbia River Gorge and their relationship top the Troutdale Formation: Geological Society of America Bulletin, v. 95, no. 4, p. 463 - 477.

Trimble, D.E., 1957, Geology of the Portland quadrangle, Oregon Washington: U.S. Geological Survey Quadrangle Map GQ-104.

, 1963, Geology of Portland, Oregon and adjacent areas:

United States Geological Survey Bulletin, 1119, map scale $1: 62,500$.

Tresher, R.C., 1942, Geologic map of the Portland area: State of Oregon Deptpartment of Geology and Mineral Industries Map.

Van Atta, Robert 0., and Kelty, Kevin B., 1985, Scappoose Formation, Columbia County, Oregon: New evidence of age relation to Columbia River Basalt group: American Assosiation of Petroleum Geologists Bulletin, v. 69, no. 5, p. $688-698$.

Warren, W.C., Norbisrath, H., and Grivetti, R.M., 1945, Geology of northwest Oregon: United States Geological Survey, 0il and Gas Investigations Preliminary Map 42, scale 1:250,000. 


\section{APPENDIX A}

Appendix A presents the refraction data that was taken directly off the field records for each line. The data is presented in the order that it was discussed in the text. This data was used for the purpose of constructing the time-distance plots.

The data is presented using the following format: 1) The values under the line column indicate, in meters, the location of the geophone array on the line. Zero meters is taken to be on the left hand side of the line on the time-distance plots. 2) The values under the shotpoint column indicate, in meters, the location where the weight was dropped. The shot points are shown in Figures $3-6$. 3) The values under the numbered columns $(1-12)$ indicate, in seconds, the first arrival times recorded by the 12 geophones. 4) The column on the right indicates the relative quality of each field record based on a scale from A-F. The record quality was determined based on the amount of background noise and the ability to pick first arrivals.

The geophone spacing was five meters between the first two geophones on each end of the line and ten meters between the other geophones which resulted in 90 meters 1ines. Exceptions to this were the 0 - 80 line on the Bonny Slope line and the 145 meter Rock Creek line. Because of limited space on the Bonny Slope line, the first array was set up with five meter spacing between the first three phones on each end of the line and ten meters between the other phones. Because of limited time completing the Rock Creek 1ine, a single 145 meter line 
was set up using a ten meter spacing between the three phones at each end of the line and fifteen meters between the other phones. 


\section{Thougsco acad Line}

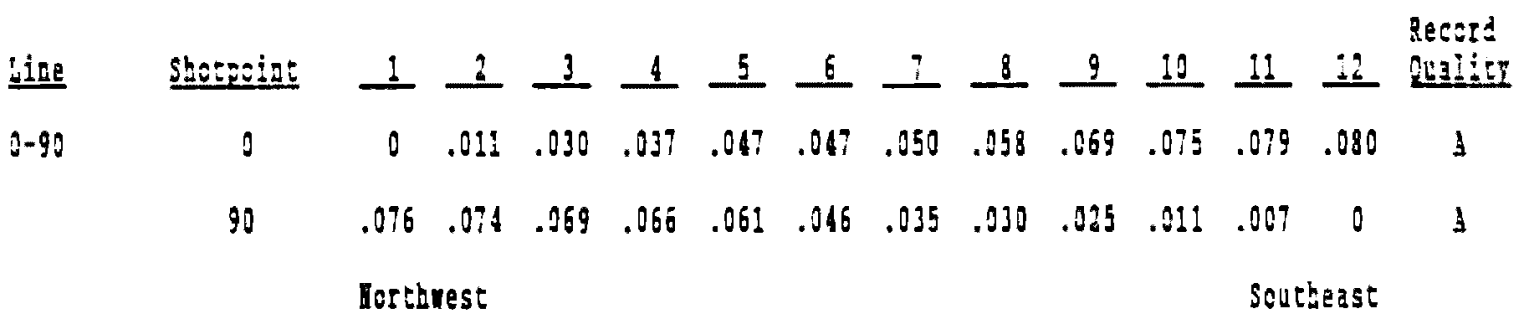

\section{Bonar Slape ine}

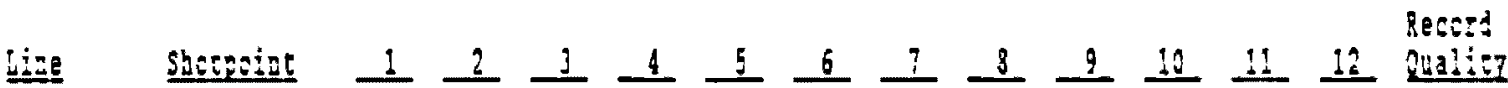

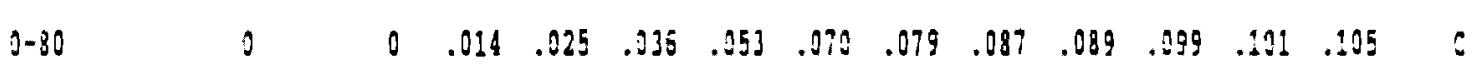
$\begin{array}{lllllllllllllll}80 & .117 & .116 & .110 & .098 & .081 & .070 & .057 & .035 & .023 & .012 & .014 & 0 & & 8\end{array}$ $\begin{array}{llllllllllllll}170 & .118 & .117 & .112 & .197 & .103 & .190 & .099 & .095 & .084 & .076 & .076 & .072 & 0\end{array}$ $\begin{array}{lllllllllllllll}80-199 & 30 & 0 & 009 & 016 & .034 & .044 & .059 & .999 & .076 & .083 & .090 & .092 & .093 & 6\end{array}$ $\begin{array}{lllllllllllllll}190 & .073 & .066 & .051 & .059 & .052 & .048 & .049 & .034 & .045 & .017 & .014 & 0 & & 3\end{array}$

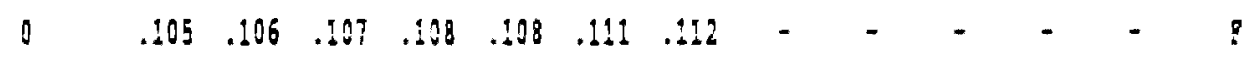
$\begin{array}{lllllllllllllll}170-260 & 190 & 0 & .013 & .017 & .025 & .033 & .042 & .047 & .052 & .059 & .062 & .066 & .064 & 1\end{array}$ $\begin{array}{lllllllllllllll}260 & .061 & .059 & .059 & .053 & .052 & .043 & .040 & .034 & .025 & .014 & .009 & 0 & & 3\end{array}$

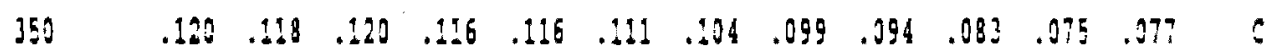
$\begin{array}{lllllllllllllll}960-250 & 260 & 0 & .008 & .019 & .097 & .037 & .045 & .050 & .060 & .062 & .064 & .090 & .072 & 1\end{array}$ $\begin{array}{lllllllllllllll}359 & .077 & .076 & .093 & .073 & .070 & .054 & .057 & .050 & .039 & .018 & .008 & 0 & & 1\end{array}$

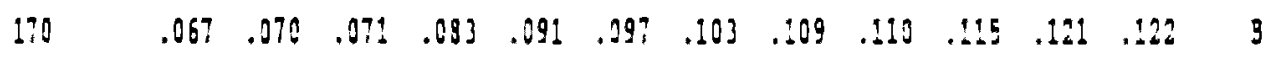
Scrthres: Scutheast 


\section{Laidian Soad tine}

\begin{tabular}{|c|c|c|c|c|c|c|c|c|c|c|c|c|c|c|}
\hline Lirge & Shot=oinc & 1 & 2 & 3 & 4 & 5 & 6 & 1 & 8 & 9 & 10 & 19 & 12 & $\begin{array}{l}\text { Recsid } \\
\text { puabieg }\end{array}$ \\
\hline \multirow[t]{3}{*}{$0-90$} & 0 & 0 & .006 & .025 & .029 & .035 & .039 & .042 & .051 & .062 & .069 & .070 & .071 & C \\
\hline & 90 & .072 & .070 & - & .055 & .056 & .046 & .040 & .038 & .032 & .014 & .006 & 0 & $c$ \\
\hline & & Mest & & & & & & & & & & & East & \\
\hline
\end{tabular}

\section{Brogson crees jine}

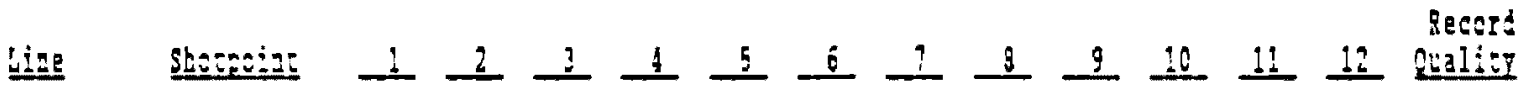
$0-90$

0.004 .01

$\begin{array}{llllllllllllllll}90 & .090 & - & - & .086 & .082 & .076 & .062 & .049 & .033 & .021 & .099 & 0 & 1\end{array}$

$189 \quad \begin{array}{lllllllllllll}126 & .126 & .127 & .127 & .126 & .226 & .127 & .226 & .123 & .119 & .124 & .218 & \text { 6 }\end{array}$

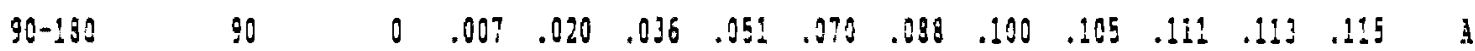

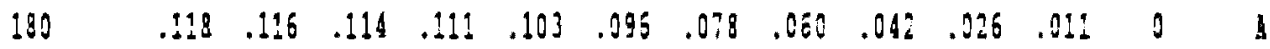

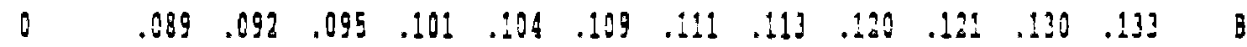

$\begin{array}{lllllllllllllll}180-270 & 190 & 0 & .008 & .020 & .044 & .058 & .075 & .086 & .093 & .099 & .100 & .194 & .105 & 1\end{array}$

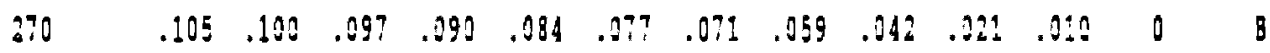

$\begin{array}{llllllllllllll}360 & 142 & .133 & .141 & .129 & .121 & .116 & .113 & .297 & .091 & .081 & .079 & .075 & 0\end{array}$

$\begin{array}{llllllllllllllll}270-360 & 270 & 0 & .009 & .021 & .037 & .041 & .046 & .053 & .060 & .068 & .079 & .063 & .069 & 1\end{array}$

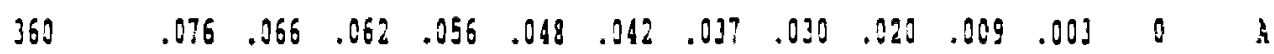

$\begin{array}{llllllllllllll}130 & 195 & .104 & .105 & .109 & .110 & .119 & .125 & .131 & .139 & .141 & .142 & .14 ! & 0\end{array}$

liste

souts 


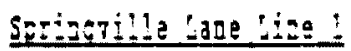

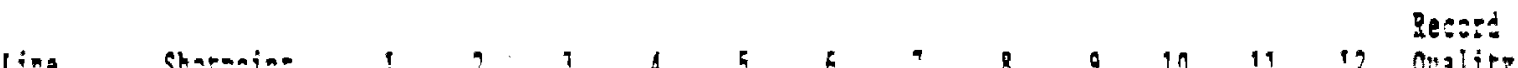

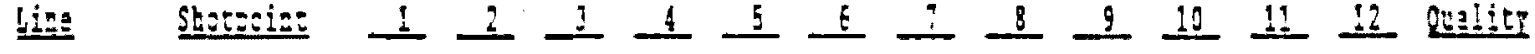

$\begin{array}{lllllllllllllll}0-90 & 0 & 0 & .007 & .020 & .032 & .039 & .069 & .053 & .057 & .06 \% & .084 & .086 & .085 & 1\end{array}$

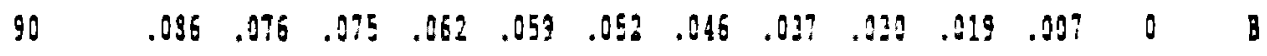

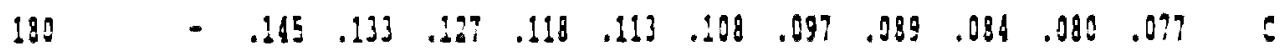

$\begin{array}{lllllllllllllll}90-2.90 & 90 & 0 & .009 & .029 & .921 & .037 & .045 & .058 & .056 & .065 & .070 & .072 & .073 & 9\end{array}$

$\begin{array}{llllllllllllll}280 & .079 & 0.079 & .067 & .057 & .054 & .049 & .039 & .036 & .029 & .019 & .097 & 0 & 1\end{array}$

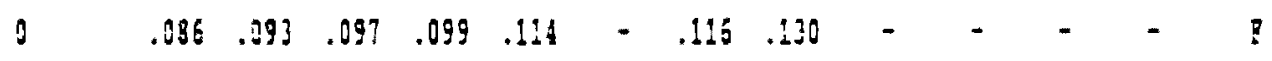

Vest

E3s:

\section{Saringring tane tine?}

\begin{tabular}{|c|c|c|c|c|c|c|c|c|c|c|c|c|c|c|}
\hline Line & Staz=ini & $\div$ & 2 & 1 & 4 & 5 & 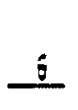 & Z & 1 & 9 & 20 & 12 & $\therefore 2$ & $\begin{array}{l}\text { lecard } \\
\text { Reslisy }\end{array}$ \\
\hline \multirow[t]{3}{*}{$3-30$} & 1 & 0 & .204 & .214 & .218 & $\therefore a B^{2}$ & .933 & .039 & .347 & $.05 !$ & .960 & .253 & .268 & 1 \\
\hline & 30 & .262 & .059 & .95 & .059 & .844 & .340 & .93 & .027 & $.92 n$ & .214 & .006 & 0 & 1 \\
\hline & 280 & .215 & $\ldots i$ & .103 & TO & .104 & .097 & .092 & .095 & .082 & .095 & .979 & .958 & م \\
\hline \multirow[t]{3}{*}{$90-\div 30$} & 90 & 0 & .008 & .019 & .925 & .831 & .039 & $.34 ?$ & - & ..$E S$ & .954 & $.36 ?$ & .869 & 1 \\
\hline & $18 B$ & .268 & .263 & IE: & .054 & .248 & .248 & .023 & .929 & . 295 & .218 & .004 & $n$ & 1 \\
\hline & 9 & $\begin{array}{l}.360 \\
10: 28\end{array}$ & .268 & .972 & .090 & .085 & .393 & .897 & - & 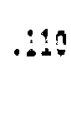 & .115 & .115 & $\begin{array}{l}.127 \\
\text { s:uts }\end{array}$ & $\exists$ \\
\hline
\end{tabular}




\section{Gergartang zoad ine}

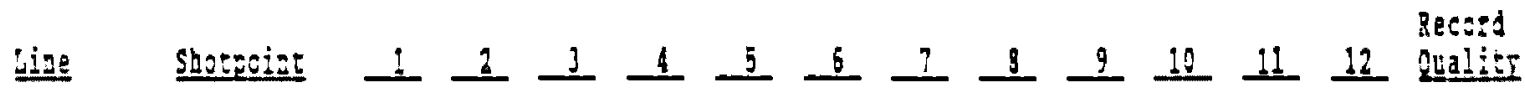
$\begin{array}{llllllllllllllll}0.98 & 0 & 0 & .013 & .013 & .019 & .024 & .038 & .034 & .038 & .042 & .047 & .045 & .049 & 1\end{array}$

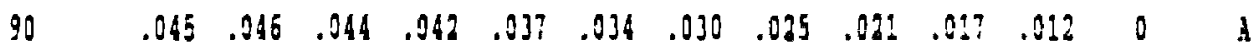
Souchrest No: :hesst

\section{Ijiser poa! inge}

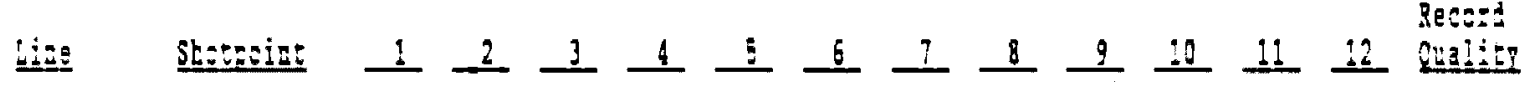
$\begin{array}{llllllllllllllll}0.99 & 0 & 0 & 0 & 008 & .017 & .025 & .038 & .033 & .037 & .040 & .041 & .042 & .043 & .046 & \text { B }\end{array}$

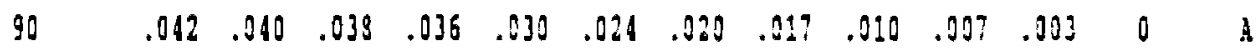
$\begin{array}{llllllllllllll}880 & 0071 & 064 & .063 & 062 & .057 & .059 & .014 & .040 & .036 & .035 & .033 & .032 & 9\end{array}$

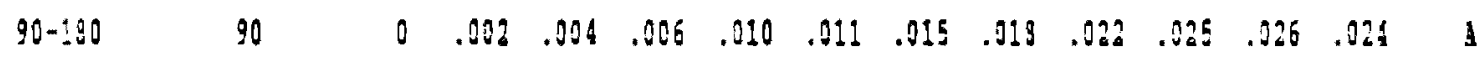
$\begin{array}{llllllllllllll}180 & .032 & - & .024 & .020 & 023 & .016 & .013 & .011 & .007 & .004 & .002 & 0 & 8\end{array}$

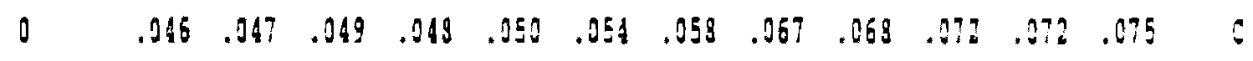
Sosth lorth

\section{gock Treak Line}

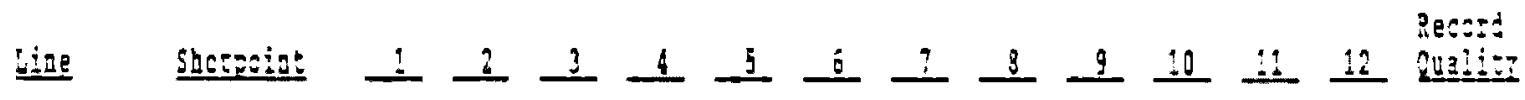
$\begin{array}{lllllllllllllll}0-145 & 0 & 0 & 019 & .027 & .036 & .048 & .044 & .048 & .058 & .054 & .057 & .068 & .053 & 0\end{array}$ $\begin{array}{llllllllllllll}145 & .092 & .085 & .079 & .078 & .073 & .060 & .060 & .050 & .039 & .029 & .016 & 0 & \text { : }\end{array}$ Nest Eas: 


\section{Cornelins ?ass inge:}

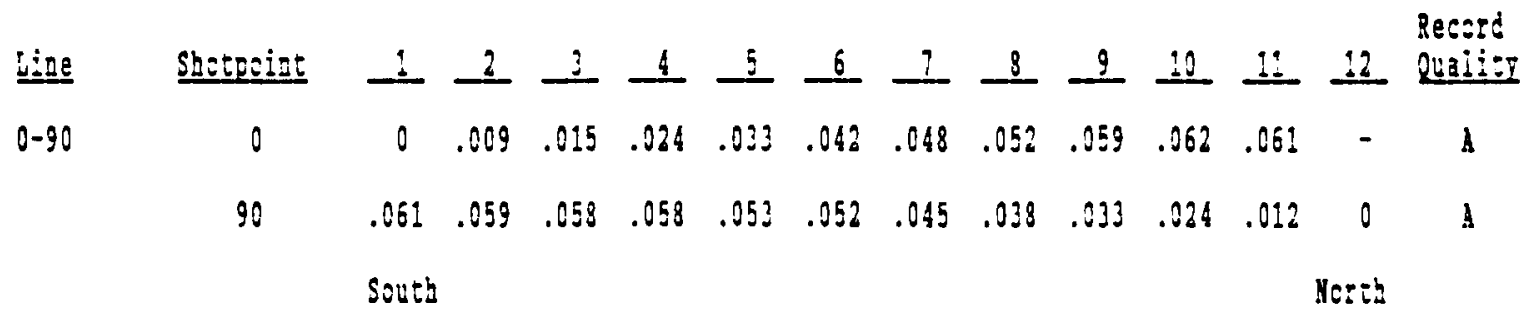

\section{Carnelius?ass :ine?}

Shoconing Recard

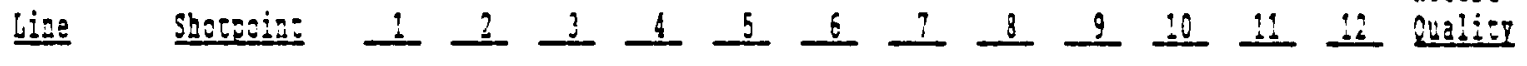
$\begin{array}{lllllllllllllll}0-90 & 0 & 0 & .014 & .018 & .029 & .025 & .041 & .049 & .057 & .060 & .060 & .052 & .061 & 3\end{array}$ $\begin{array}{llllllllllllll}90 & 0.060 & .058 & .057 & .055 & .051 & .045 & .034 & .038 & .022 & .015 & .009 & 0 & 1\end{array}$ Sevith

Scrth 
A. Critleal angle, dip, depth and thickness of layers
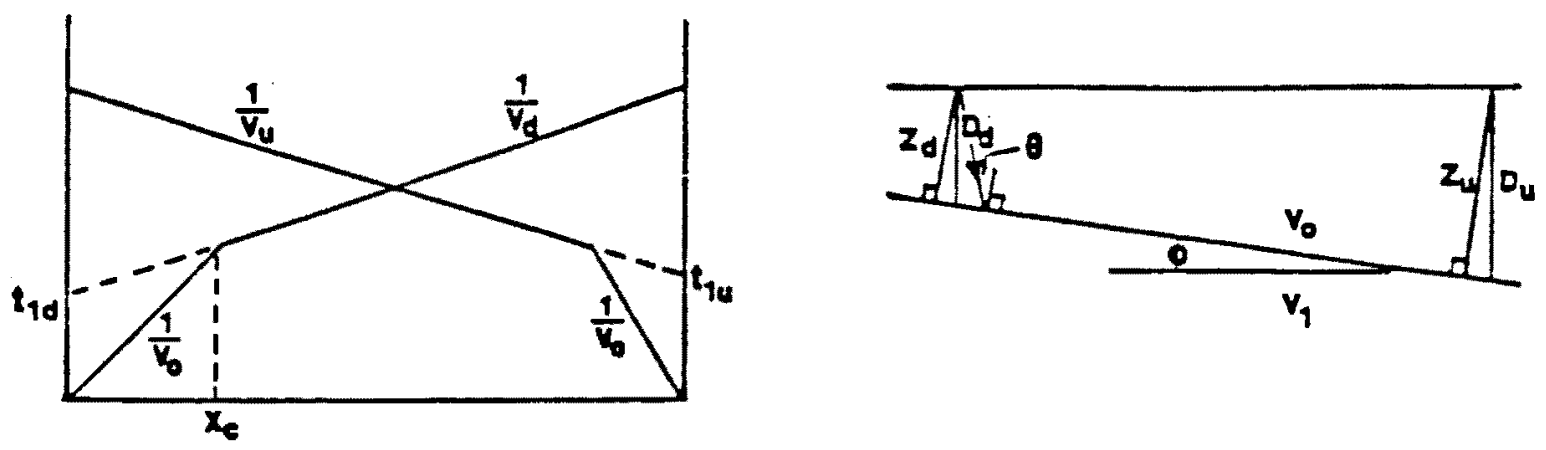

$$
\begin{aligned}
& \text { - (eritkel anglo) }=\frac{1}{2}\left[\sin ^{-1} \frac{V_{0}}{V_{0}}+\sin ^{-1} \frac{V_{0}}{V_{u}}\right] \quad \sin \theta=\frac{V_{0}}{V_{1}} \\
& \phi(d \mid p) \quad=\frac{1}{2}\left[\sin ^{-1} \frac{v_{0}}{v_{u}}-\operatorname{ain}^{-1} \frac{v_{0}}{v_{u}}\right] \quad v_{u}>v_{d} \\
& z_{d}=\frac{t_{1 d} v_{0}}{2 \cos \theta} \quad z_{u}=\frac{t_{1 u} v_{0}}{2 \cos \theta} \\
& D_{d}=\frac{z_{d}}{\cos \varphi} \quad D_{u}=\frac{z_{u}}{\cos \varphi}
\end{aligned}
$$

Multiple dlpping layer lormulas in Ewing. Woollard end Vine, 1938, and Mota, 1064.

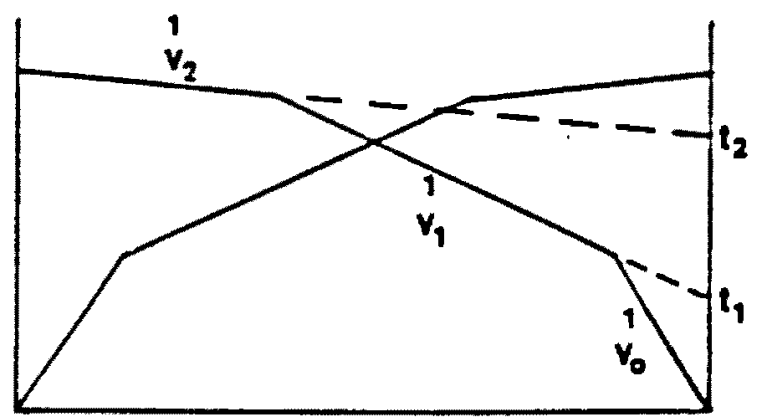

$$
v_{0}<v_{1}<v_{2}
$$

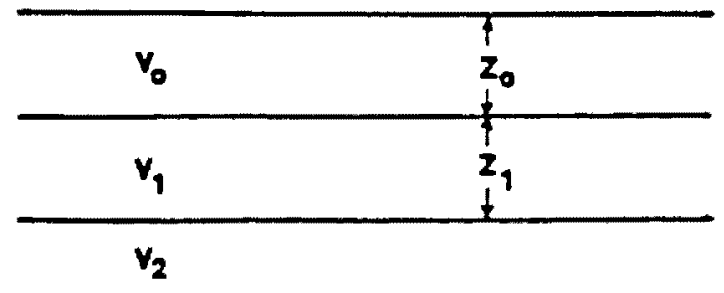

$$
\begin{aligned}
& z_{0}=\frac{t_{1}}{2} \frac{v_{1} v_{0}}{\sqrt{v_{1}^{2}-v_{0}^{2}}} \\
& z_{0}=\frac{1}{2} \sqrt{\frac{v_{1}-v_{0}}{v_{1}+v_{0}}} x_{c}
\end{aligned}
$$

$$
z_{1}=\frac{1}{2}\left(t_{2}-2 z_{0} \frac{\sqrt{v_{2}^{2}-v_{0}^{2}}}{v_{2} v_{0}}\right)\left(\frac{v_{2} v_{1}}{\sqrt{v_{2}^{2}-v_{1}^{2}}}\right)
$$


B. Fault throw:

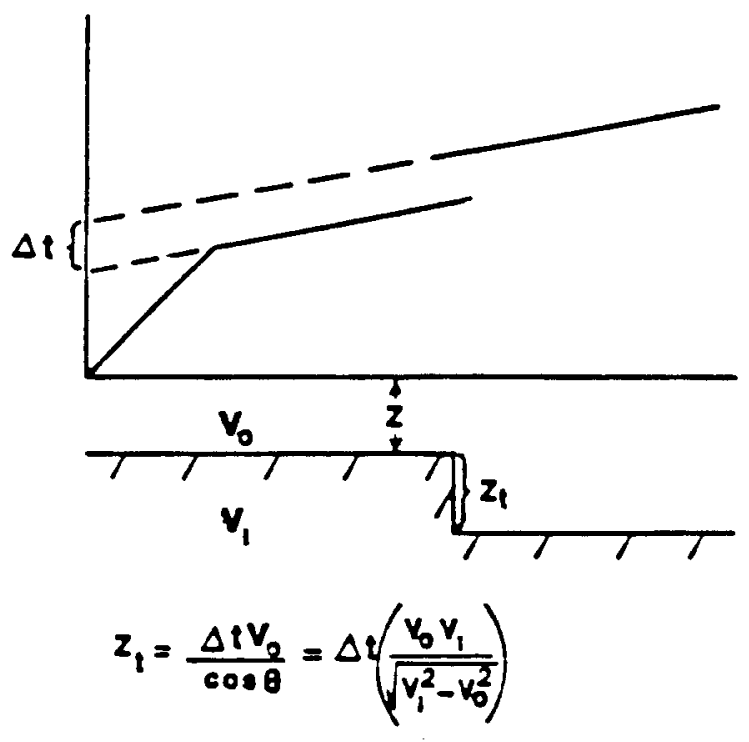


APPENDIX B

C PROGRAM THAT FITS A LINE TO A SET OF POINTS REPRESENTING

C SEISMIC REFRACTION FIELD DATA.

C THE SET OF POINTS ARE PICKED BY THE OPERATOR YHILE THE

C PROGRAM IS RUNNING.

C THE LINE IS CALCULATED BY THE LEAST SQUARES METHOD.

C THE PROGRAM CALCULATES VELOCITY, ZERO INTERCEPT, AND

C QUALITY OF FIT EACH LINE CALCULATED.

C PROGRAM HAS BEEN MODIFIED AND TRANSLATED TO FORTRAN FROM

C BASIC BY DAVE NAZY, PSU GEOLOGY DEPARTMENT.

C THE PROGRAM WAS VRITTEN BY C. B. REYNOLDS AND WAS TAREN

C FROM "MICROCOMPUTER APPLICATIONS IN GEOLOGY", P. 47-57.

C

C

C READ NAME OF SEISMIC LINE

C

89 WRITE $(*, 80)$

80 FORMAT $(/, 1$ TYPE THE NAME OF THE SEISMIC LINE',//) READ $(*, 90)$ LINE

90 FORMAT (10A4)

URITE $(*, 100)$

100 FORMAT $(/, '$ TYPE DATA FILE NAME eg. B:SEIS.DAT,$/ /)$ READ ( $* 110)$ FILENAME

110 FORMAT (A)

OPEN (5, FILE=FILENAME)

OPEN $\left(6, F I L E=' L P T 1^{\prime}\right)$

C

C READ NUMBER OF SHOT POINTS

C

NRITE $(*, 200)$

200 FORMAT $(/$, ' HOW MANY SBOT POINTS ARE THERE ON THIS LINE?,$/ /$ ) READ $(*, *)$ NSP DO $10 I=1$, NSP

c

C READ DATA FILE

C

CALL READM (DATA, N, M, 100,2)

DO $20 \mathrm{~J}=1, \mathrm{~N}$

DO $20 \mathrm{~K}=1, \mathrm{M}$

IF (I.EQ.1) A $(J, K)=\operatorname{DATA}(J, K)$

IF (I.EQ.2) $B(J, R)=\operatorname{DATA}(J, R)$

IF (I.EQ.3) $C(J, K)=\operatorname{DATA}(J, K)$ 
IF (I.EQ.4) D (J,K) $=\operatorname{DATA}(J, K)$

20 CONTINUE

10 CONTINUE

C

C

C

299 WRITE $(*, 300)$

300 FORMAT (/,' WHICH SHOT POINT DO YOU YANT TO WORK WITH? './/) URITE $(\star, 310)$

310 FORMAT $\left(/, 10 \mathrm{X},{ }^{\prime} 1\right.$ - SHOT PT A ',10X,' 2 - SHOT PT B ',//,10X,' 3

1- SEOT PT C ',10X,'4 - SHOT PT D ',//1)

$\operatorname{READ}(*, *) \mathrm{N} 1$

DO $30 \mathrm{~J}=1, \mathrm{~N}$

DO $30 \quad R=1, M$

IF (N1.EQ.1) XT $(J, K)=A(J, K)$

IF (N1.EQ.2) XT $(J, K)=B(J, K)$

IF (N1.EQ.3) XT $(J, K)=C(J, K)$

IF (N1.EQ.4) XT $(J, R)=D(J, K)$

30 CONTINUE

C

C

C

399 VRITE $(\$, 400)$

400 FORMAT $(/$, ' TYPE THE NUMBER OF THE FIRST PHONE YOU WANT FIT ON

1 THE LINE ', /)

READ $(*, *)$ N2

HRITE $(*, 420)$

420 FORMAT $(/, '$ TYPE THE NUMBER OF THE LAST PHONE YOU WANT FIT ON THE ILINE,$/ 1$

$\operatorname{READ}(*, *)$ N3

C

C CALCULATE VELOCITY, ZERO INTERCEPT TIME, AND QUALITY OF FIT

C

$N 4=(N 3-N 2)+1$.

$X D=0.0$

$T D=0.0$

$X T D=0.0$

$\mathrm{XQD}=0.0$

$T Q D=0.0$

DO $40 \quad I=\mathrm{N}_{2}, \mathrm{~N} 3$

$X D=X D+X T(I, 1)$

$\mathrm{TD}=\mathrm{TD}+\mathrm{XT}(I, 2)$

$X T D=X T D+X T(I, 1) \star X T(I, 2)$

$X Q D=X Q D+X T(I, 1) \star \star 2$

$T Q D=T Q D+X T(I, 2) \star \star 2$

40 CONTINUE

$X M I=(X T D-(X D * T D) / N 4) /(X Q D-(X D * 2) / N 4)$

$I N T=1000 *(T D-X M 1 \star X D) / N 4+0.5$

$Z I N T=I N T / 1000$.

VEL $=1 / X M 1$

IRSQ $=1000 \star$ XMI* $(X D * T D / N 4-X T D) /(T Q D-(T D \star \star 2) / N 4)-0.5$

$R S Q=(I R S Q / 1000) *.(-1.0)$

C PRINT RESULTS 
URITE $(6,450)$ LINE

450 FORMAT (10A4)

IF (N1.NE.1) GO TO 461

URITE $(6,460)$

460 FORMAT (//,' VELOCITY CALCULATED FROM SHOT POINT A')

461 IF (N1.NE.2) GO TO 471

WRITE $(6,470)$

470 FORMAT (//,' VELOCITY CALCULATED FROM SHOT POINT B')

471 IF (N1.NE.3) GO TO 481

NRITE $(6,480)$

480 FORMAT (//,' VELOCITY CALCULATED FROM SHOT POINT $\left.C^{\prime}\right)$

481 IF (N1.NE.4) GO TO 491

VRITE $(6,490)$

490 FORMAT (//,' VELOCITY CALCULATED FROM SHOT POINT D')

491 WRITE $(6,500)$ VEL

500 FORMAT $\left(/,{ }^{\prime}\right.$ VELOCITITY OF LINE FIT TO DATA IS ',F8.2,' M/SEC') WRITE $(6,510)$ ZINT

510 FORMAT (/,' THE ZERO INTERCEPT OF THE LINE IS ',F6.4,' SECONDS') WRITE $(6,520) \times 2, N 3$

520 FORMAT (/,' THE LINE HAS FIT TO GEOPHONES ', I2,' -1, I2)

WRITE $(6,530)$ RSQ

530 FORMAT $(/, 1$ THE QUALITY OF LINE FIT IS ',F5.2)

WRITE $(6,540)$

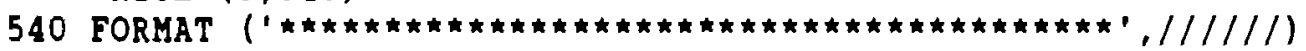

C

C READ TO CONTINUE OR EXIT PROGRAM

$\mathrm{C}$

WRITE $(*, 600)$

600 FORMAT $(/ /, '$ DO YOU WANT TO CALCULATE ANY MORE VELOCITIES ?', //) HRITE $(*, 610)$

610 FORMAT $(/, 10 \mathrm{X}, ' 1$ - YES, SAME LINE, SAME SHOT POINT', /,10X,' 2 1YES, SAME LINE, DIFFERENT SHOT POINT',/,10X,' 3 - YES, DIFFERENT 2LINE', /,10X,' 4 - NO, EXIT PROGRAM')

$\operatorname{READ}(*, *)$ M4

IF (M4.EQ.1) GO TO 399

IF (M4.EQ.2) GO TO 299

IF (M4.EQ.3) GO TO 89

STOP

END

C

SUBROUTINE READM(E,N,M,N1,M1)

DIMENSION E (N1, M1)

C READ SIZE OF MATRIX

READ $(5,1000) N, M$

C READ MATRIX ONE RON AT A TIME

DO $1001 \quad I=1, N$

$\operatorname{READ}(5,1002) \quad(E(I, J), J=1, M)$

1001 CONTINUE

RETURN

1000 FORMAT (2I2)

1002 FORMAT (2F7.3)

END 
C

C

C

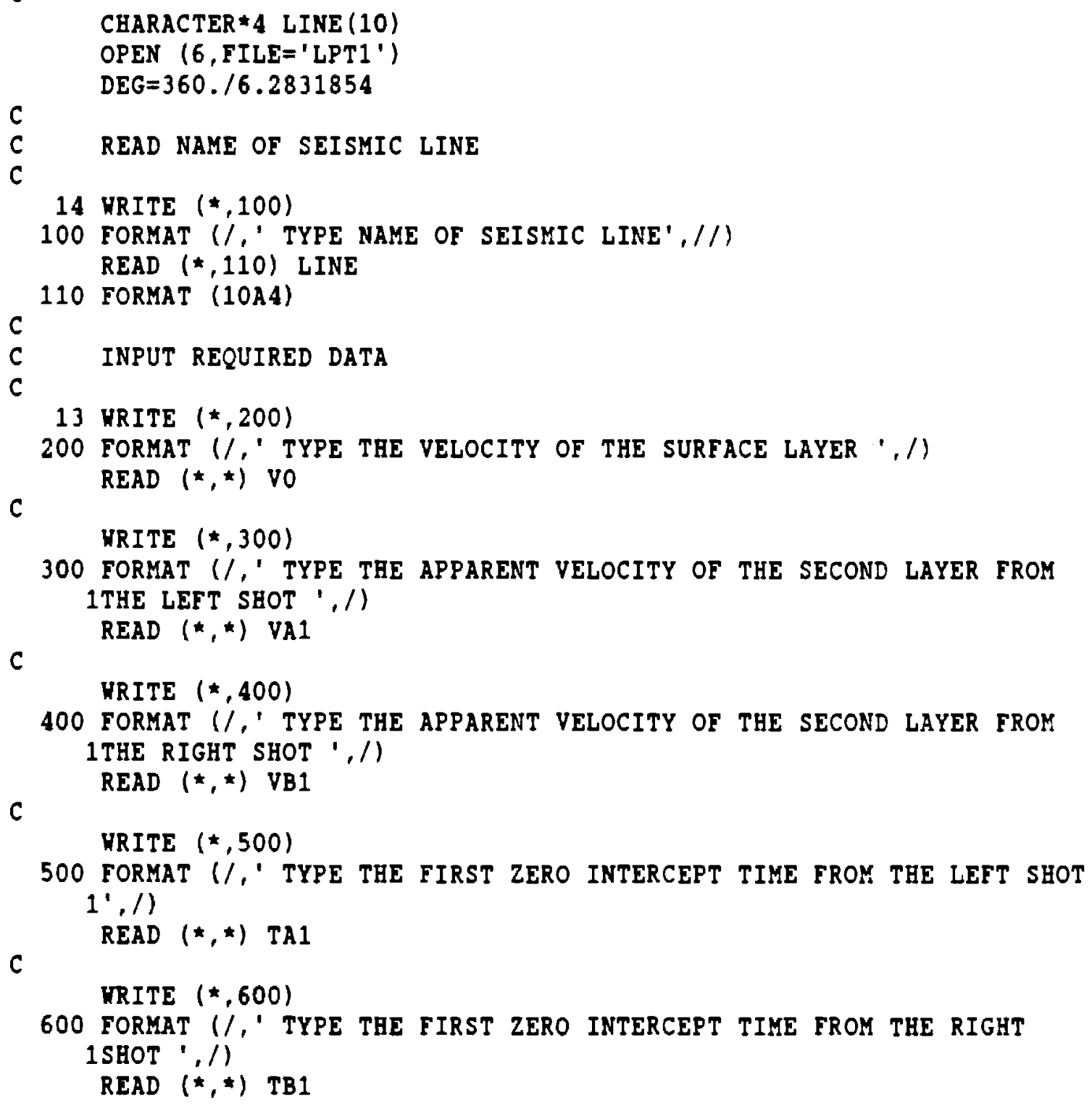


C

(VA1.GT.VB1) THEN

$$
\text { IDIP } 1=1
$$

ELSE

$$
\text { IDIP } 1=2
$$

C

ENDIF

$$
\text { URITE }(\star, 610)
$$

610 FORMAT (/, ARE THERE THREE LAYERS IN YOUR MODEL ? ',/) URITE $(*, 620)$

620 FORMAT (/,' TYPE 1 FOR YES, 2 FOR NO ',/)

$\operatorname{READ}(*, *) I$

C

IF (I.EQ.2) GO TO 10

C

URITE $(*, 700)$

700 FORMAT / $/, '$ TYPE THE APPARENT VELOCITY OF THE THIRD LAYER FROM 1THE LEFT SHOT ',/l

C

$$
\operatorname{READ}(*, *) \text { VA2 }
$$

$$
\text { NRITE }(\star, 800)
$$

800 FORMAT $(/, '$ TYPE THE APPARENT VELOCITY OF THE THIRD LAYER FROM 1THE RIGHT SHOT ',/

C

$$
\operatorname{READ}(*, *) \text { VB2 }
$$

\section{URITE $(*, 900)$}

900 FORMAT (/,' TYPE THE SECOND ZERO INTERCEPT TIME FROM THE LEFT ISHOT', /)

C

READ (*,*) TA2

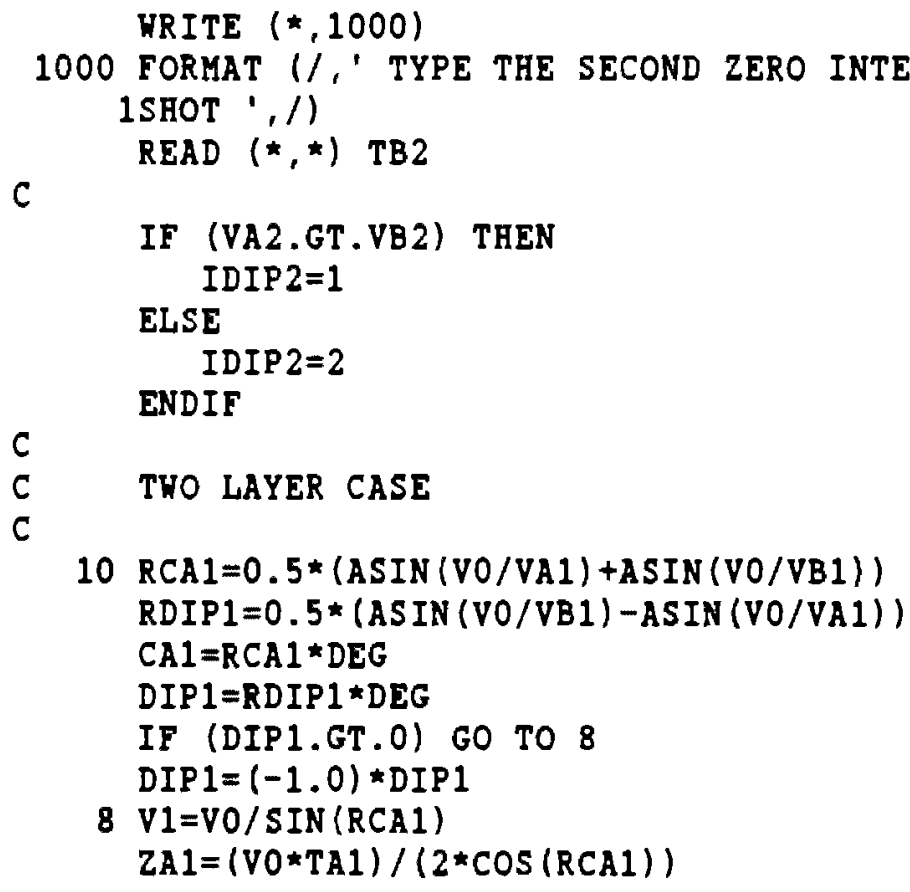




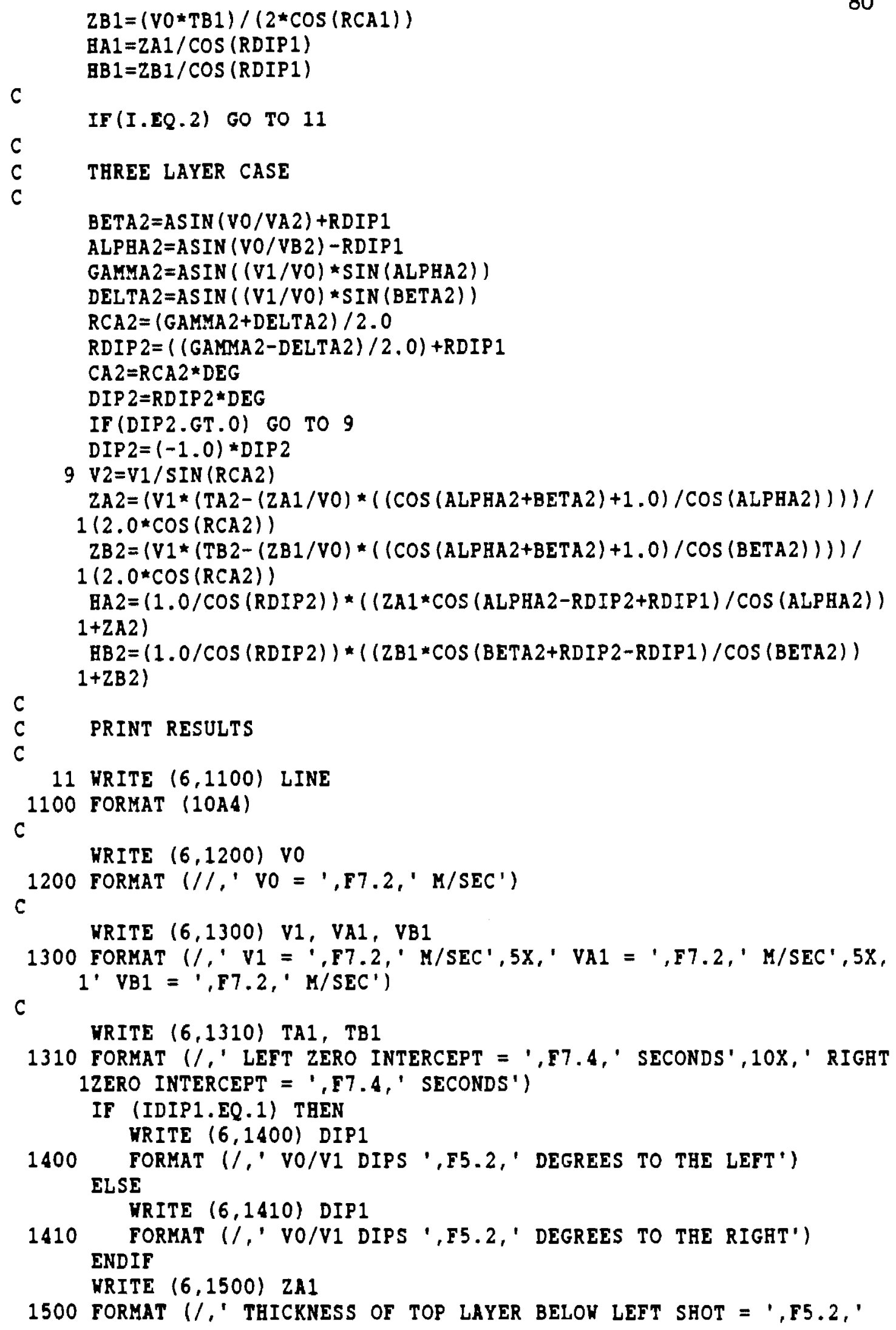


URITE $(6,1600)$ ZB1

1600 FORMAT (/,' THICKNESS OF TOP LAYER BELOW RIGHT SHOT = ',F5.2,' 1METERS ')

YRITE $(6,1700)$ BA1

1700 FORMAT (/,' DEPTH TO V1 BELOW THE LEFT SHOT = ',F5.2,' METERS') URITE $(6,1800)$ HB1

1800 FORMAT (/,' DEPTH TO V1 BELOW THE RIGET SHOT = ',F5.2,' METERS') NRITE $(6,1900)$ CAI

1900 FORMAT $(/, '$ CRITICAL ANGLE (VO/V1) = ',F5.2,' DEGREES',/) C

C IF (I.EQ.2) GO TO 12

WRITE $(6,1910) \mathrm{V} 2, \mathrm{VA2}, \mathrm{VB} 2$

1910 FORMAT $\left(/, g^{\prime} \mathrm{V} 2=', F 7.2,{ }^{\prime} \mathrm{M} / \mathrm{SEC}, 5 \mathrm{X},{ }^{\prime} \mathrm{VA2}=\right.$ ',F7.2,' M/SEC',5X,' $1 \mathrm{VB} 2=', F 7.2, \mathrm{M} / \mathrm{SEC})$

VRITE $(6,1920)$ TA2, TB2

1920 FORMAT $(/, '$ 2nd LEFT INTERCEPT = ',F7.4,' SECONDS',10X,' 2nd

1 RIGHT INTERCEPT $=$ ',F7.4,' SECONDS')

IF (IDIP2.EQ.1) THEN

WRITE $(6,2000)$ DIP2

2000 FORMAT (/,' V1/V2 DIPS ',F5.2,' DEGREES TO THE LEFT') ELSE

URITE $(6,2010)$ DIP2

2010 FORMAT (/,' V1/V2 DIPS ',F5.2,' DEGREES TO THE RIGHT') ENDIF

VRITE $(6,2100)$ ZA2

2100 FORMAT $(/, '$ THICKNESS OF 2ND LAYER BELOW LEFT SHOT = ',F5.2,' 1METERS ' )

URITE $(6,2200)$ ZB2

2200 FORYAT $(/, '$ THICKNESS OF 2ND LAYER BELOH RIGHT SHOT = ',F5.2,' 1METERS ')

WRITE $(6,2300)$ HA2

2300 FORMAT $(/, '$ DEPTH TO V2 BELON THE LEET SHOT = ',F5.2,' METERS') WRITE $(6,2400)$ HB 2

2400 FORMAT $(/, '$ DEPTH TO V2 BELOW THE RIGHT SHOT = ',F5.2,' METERS') URITE $(6,2500)$ CA2

2500 FORMAT (/,' CRITICAL ANGLE (V1/V2) = ',F5.2,' DEGREES', /) C

12 VRITE $(6,2600)$

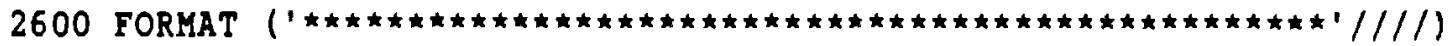
URITE $(*, 2700)$

2700 FORMAT $(/ / / /, '$ DO YOU WANT TO CALCULATE ANY MORE VELOCITIES AND 1DIPS? ', //)

URITE $(*, 2800)$

2800 FORMAT $(/, 10 \AA, ' 1$ - YES, USING THE SAME LINE ', //,10X,' 2 - YES, IUSING A DIFFERENT LINE ', //,10X,' 3 - NO, EXIT PROGRAM ',/)

$\operatorname{READ}(*, *) \mathrm{J}$

IF (J.EQ.1) GO TO 13

IF (J.EQ.2) GO TO 14

STOP

END 